UNIVERSIDADE DE SÃO PAULO

ESCOLA DE ENFERMAGEM

KARINA GOMES LOURENÇO MENDES

A PARTICIPAÇÃO DAS ENFERMEIRAS NA GESTÃO DE CUSTOS EM ORGANIZAÇÕES HOSPITALARES

SÃO PAULO

2011 
KARINA GOMES LOURENÇO MENDES

\section{A PARTICIPAÇÃO DAS ENFERMEIRAS NA GESTÃO DE CUSTOS EM ORGANIZAÇÕES HOSPITALARES}

Tese apresentada à Escola de Enfermagem da Universidade de São Paulo para obtenção do Título de Doutor em Ciências

Área de concentração: Fundamentos e Práticas de Gerenciamento em Enfermagem e em Saúde

Orientadora: $\operatorname{Prof}^{\mathrm{a}} \mathrm{Dr}^{\mathrm{a}}$ Valéria Castilho

\section{SÃO PAULO}

2011 
AUTORIZO A REPRODUÇÃO E DIVULGAÇÃO TOTAL OU PARCIAL DESTE TRABALHO, POR QUALQUER MEIO CONVENCIONAL OU ELETRÔNICO, PARA FINS DE ESTUDO E PESQUISA, DESDE QUE CITADA A FONTE.

Assinatura:

Data:

Catalogação na Publicação (CIP)

Biblioteca "Wanda de Aguiar Horta"

Escola de Enfermagem da Universidade de São Paulo

Mendes, Karina Gomes Lourenço

A participação das enfermeiras na gestão de custos em organizações hospitalares / Karina Gomes Lourenço Mendes.-São Paulo, 2011.

$148 \mathrm{p}$.

Tese (Doutorado) - Escola de Enfermagem da Universidade de São Paulo.

Orientadora: Prof ${ }^{\mathrm{a}} \operatorname{Dr}^{\mathrm{a}}$ Valéria Castilho

1. Hospitais - Custos 2. Custos em enfermagem

3. Administração em enfermagem 4. Enfermagem I. Título. 
Nome: Karina Gomes Lourenço Mendes

Titulo: A participação das enfermeiras na gestão de custos em organizações hospitalares.

Tese apresentada à Escola de Enfermagem da Universidade de São Paulo para obtenção do título de Doutor em Ciências.

Aprovado em:

\section{Banca Examinadora}

Prof. Dr. Instituição:

Julgamento: Assinatura:

Prof. Dr. Instituição:

Julgamento: Assinatura:

Prof. Dr. Instituição:

Julgamento: Assinatura:

Prof. Dr. Instituição:

Julgamento: Assinatura:

Prof. Dr. Instituição: Julgamento: Assinatura: 


\section{Dedicatória}

Ao meu marido e minha filha, por motivarem-me sempre com palavras de apoio ao longo desse processo de desenvolvimento pessoal e profissional e por me incentivarem para concluir com sucesso mais este trabalho.

Aos meus familiares, pelo amor, compreensão e por compartilharem todos os momentos da minha vida. 
A DEUS por cuidar sempre de mim me guiando pelos melhores caminhos.

À Profa Dra Valéria Castilho, pelo apoio, incentivo, carinho, dedicação e por sempre disponibilizar tempo, mesmo diante de muitas atividades.

Às Prof ${ }^{a}$ Dr $^{a}$ Vera Lúcia Mira Gonçalves e Profa ${ }^{a} r^{a}$ Fernanda Maria Togeiro Fugulin, pelas orientações e sugestões durante o exame de qualificação.

À Enfa. Cristina Vogel, pela recepção, interesse, participação neste estudo e ilustre generosidade na troca de experiências oferecida de maneira voluntária.

Enfim, a todos aqueles que de alguma maneira contribuíram durante toda minha trajetória, meu carinho e minha gratidão.

A todos, muito obrigada! 
Mendes KGL. A participação das enfermeiras na gestão de custos em organizações hospitalares [tese]. São Paulo: Escola de Enfermagem, Universidade de São Paulo; 2011.

\section{RESUMO}

O crescimento dos custos no setor de saúde é decorrente de vários fatores, entre eles, a falta de capacitação administrativa dos gerentes e a não implementação de sistemas de controle de custos. Hoje, as instituições de saúde se esforçam para manter elevado o nível de qualidade da assistência prestada ao paciente, e ao mesmo tempo, apresentar um rendimento contábil. Para que haja um equilíbrio entre estes dois fatores, há necessidade de controle de gastos e custos e é fundamental que estes tenham início na área operacional, com a equipe de enfermagem que atua no registro, prescrição e realização dos cuidados. A enfermeira é a profissional apontada como tendo potencial para a realização deste gerenciamento, pois ao mesmo tempo em que possui domínio dos conhecimentos específicos da assistência de enfermagem, é membro integrante do grupo de profissionais que estuda desde a graduação o gerenciamento de custos podendo com isto, aprofundar seus conhecimentos na área e atuar com segurança no gerenciamento. Diante disto, este estudo teve como objetivos analisar a participação das enfermeiras no gerenciamento de custos em organizações hospitalares no município de São Paulo, levantar as atividades desenvolvidas por estas relacionadas à gestão de custos, apresentar o conhecimento destas sobre custos e métodos de custeio, verificar as dificuldades e as facilidades destas relacionadas às atividades de gerenciamento de custos e identificar as vantagens que essa participação tem trazido para o gerenciamento do serviço de enfermagem. $O$ estudo foi de cunho exploratório-descritivo comparativo e correlacional, com abordagem quantitativa e os resultados mostraram que 138 (73,8\%) enfermeiras não conhecem os custos do seu setor, $151(81,2 \%)$ enfermeiras não conhecem o sistema de custeio utilizado na instituição, $167(89,8 \%)$ enfermeiras não conhecem o orçamento do serviço de enfermagem, 162 $(87,1 \%)$ enfermeiras não conhecem o orçamento do seu setor, $168(89,8 \%)$ enfermeiras não participam da elaboração do orçamento do setor, 171 $(91,9 \%)$ enfermeiras não possuem acesso às informações necessárias para elaboração deste orçamento. Com relação à análise do conhecimento das enfermeiras sobre principais conceitos de custos hospitalares, os resultados identificaram que $76(40,6 \%)$ enfermeiras possuem conhecimento geral sobre custos, $66(35,3 \%)$ enfermeiras possuem conhecimento mínimo sobre os conceitos de custos, $111(59,4 \%)$ enfermeiras possuem conhecimento mínimo sobre as classificações de custos, $70(37,4 \%)$ enfermeiras possuem conhecimento mínimo sobre a departamentalização dos custos, $70(37,4 \%)$ enfermeiras possuem conhecimento mínimo sobre os métodos de apropriação de custos. Analisando as condições institucionais para a realização do gerenciamento de custos, os resultados encontrados apontaram que $161(86,1 \%)$ enfermeiras não se sentem preparadas para gerenciar custos, $140(74,9 \%)$ encontram dificuldades neste gerenciamento entre elas $65(36 \%)$ referem falta de conhecimento específico no assunto, 
$134(71,35 \%)$ encontram vantagens no gerenciamento de custos, pois possibilita identificar desperdícios, avaliar o custo dos materiais e novos investimentos, $148(79,15 \%)$ acreditam que o gerenciamento de custos é uma atribuição da enfermeira. Assim, os resultados deste estudo demonstraram a necessidade de utilização das ferramentas gerenciais em custos e o aprimoramento das enfermeiras sobre o assunto para contribuir com a participação destas no gerenciamento de custos hospitalares.

PALAVRAS-CHAVE: controle de custos, administração hospitalar, enfermagem. 
Mendes KGL. The participation of nurses in management costs in hospital organizations [thesis]. São Paulo (SP), Brasil: Escola de Enfermagem, Universidade de São Paulo; 2011.

\section{ABSTRACT}

The growth of costs in the healthcare industry is due to several factors, among them the lack of administrative training of managers and the nonimplementation of cost control systems. Today, healthcare institutions strive to maintain a high level of quality of care provided to the patient, and at the same time, submit an accounting income. So to get a balance between these two factors, there is need for control of spending and costs and it is vital that these operations beginning in the operational area, with the nursing team that plays in the registry, prescription and realization of care. The nurse is professional singled out as having potential for realization of this management, because while she has specific knowledge of the field of nursing assistance is an integral member of the group of professionals that studies since graduating managing costs and with this deepen their knowledge in the area and acting safely in management. Before this, this study had as objectives to analyze the participation of nurses in cost management in hospital organizations in São Paulo, raise the activities developed by these related to cost management, presenting the knowledge of these about costs and costing methods, check the difficulties and the facilities of these related to cost management activities and identify the benefits that such participation has brought to the management of nursing service. The study was exploratory-descriptive purposes and comparative correlacional study, with quantitative approach and the results showed that $138(73.8 \%)$ nurses do not know the costs of your industry, $151(81.2 \%)$ nurses do not know the costing system used at the institution, $167(89.8 \%)$ nurses do not know the budget of the nursing service, $162(87.1 \%)$ nurses do not know the budget of your sector, $168(89.8 \%)$ nurses do not participate in the budget sector, $171(91.9 \%)$ nurses do not have access to information necessary for drawing up this budget. With respect to the review of the knowledge of the main concepts of nurses on hospital costs, the results identified that $76(40.6 \%)$ nurses have general knowledge about costs, 66 $(35.3 \%)$ nurses have minimum knowledge about the concepts of costs, 111 $(59.4 \%)$ nurses have minimum knowledge about the sorts of costs, 70 $(37.4 \%)$ nurses have minimum knowledge about the departmentalization of costs, $70(37.4 \%)$ nurses possess minimal knowledge on methods of ownership costs. Analyzing the institutional conditions for the realization of cost management, the results found pointed out that $161(86.1 \%)$ nurses do not feel prepared to manage costs, $140(74.9 \%)$ encounter difficulties in managing among them 65 (36\%) concern the lack of specific knowledge on the subject, $134(71.35 \%)$ find advantages in cost management, because it makes it possible to identify waste, assess the cost of materials and new investments, $148(79.15 \%)$ believe that managing costs is an assignment of the nurse. Thus, the results of this study demonstrated the need for use of managerial tools in cost and improvement of nurses on the subject to contribute with the participation of these in the management of hospital costs.

KEYWORDS: Cost control, hospital administration, nursing. 


\section{LISTA DE ILUSTRAÇÕES}

Figura 1 - Critérios de rateio para custos indiretos 36

Figura 2 - Critérios de rateio para centros de custos auxiliares e administrativos.

Figura 3 - Resumo da classificação de gastos 39

Figura 4 - Distribuição de freqüências dos 13 juízes em relação à idade .. 65 Figura 5 - Distribuição de freqüências dos 13 juízes em relação à graduação. 66

Figura 6 - Distribuição de freqüências dos 13 juízes em relação ao tempo de formado. 66

Figura 7 - Distribuição de freqüências dos 13 juízes em relação ao tempo na função

Figura 8 - Distribuição de freqüências dos 13 juízes em relação à natureza da instituição

Figura 9 - Distribuição de freqüências dos 13 juízes em relação ao cargo/função 68

Figura 10 - Distribuição de freqüências dos 13 juízes em relação à titulação 68

Figura 11 - Sugestões dos juízes no julgamento do questionário 71

Figura 12 - Perfil das instituições de saúde do estudo 75

Figura 13 - Perfil das gestoras da área de enfermagem das instituições de saúde do estudo 76

Figura 14 - Dados sobre gerenciamento de custos das instituições de saúde do estudo 77

Figura 15 - Distribuição das enfermeiras segundo a faixa etária 78

Figura 16 - Distribuição das enfermeiras segundo o cargo 79

Figura 17 - Distribuição das enfermeiras segundo a titulação 81 
Figura 18 - Percentual de enfermeiras que identificam vantagens no gerenciamento de custos ..................................................................... 110

Figura 19 - Características quanto ao gênero das enfermeiras das

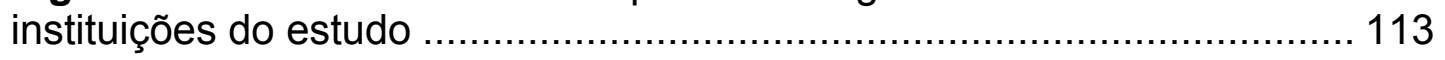




\section{LISTA DE TABELAS}

Tabela 1 - Consenso de julgamento pelos juízes dos itens dos conteúdos 70 Tabela 2 - Distribuição das 187 enfermeiras segundo o cargo e titulação . 79

Tabela 3 - Distribuição das áreas de titulação das 168 enfermeiras 82

Tabela 4 - Freqüências absolutas e relativas das respostas das questões 8 a 18 , relativas às praticas gerenciais de custos.

Tabela 5 - Freqüências absolutas e relativas das justificativas das questões relativas às praticas gerenciais de custos....

Tabela 6 - Distribuição de freqüências das 187 enfermeiras, segundo as respostas da questão 19 .

Tabela 7 - Distribuição de freqüências das 187 enfermeiras, segundo as respostas da questão 20 .

Tabela 8 - Distribuição de freqüências das 187 enfermeiras, segundo as respostas da questão 21

Tabela 9 - Distribuição de freqüências das 187 enfermeiras, segundo as respostas da questão 22 .

Tabela 10 - Distribuição de freqüências dos 187 enfermeiras, segundo as respostas da questão 23 .

Tabela 11 - Distribuição de freqüências das 187 enfermeiras, segundo as respostas da questão 24 ...

Tabela 12 - Distribuição de freqüências das 187 enfermeiras, segundo as respostas da questão 25 .

Tabela 13 - Distribuição de freqüências das 187 enfermeiras, segundo as respostas da questão 26 .

Tabela 14 - Distribuição de freqüências das 187 enfermeiras, segundo as respostas da questão 27 .

Tabela 15 - Distribuição de freqüências das 187 enfermeiras, segundo as respostas da questão 28 .

Tabela 16 - Distribuição de freqüências das 187 enfermeiras, segundo as respostas da questão 29 . 
Tabela 17 - Distribuição de freqüências das 187 enfermeiras, segundo as respostas da questão 30 .

Tabela 18 - Distribuição de freqüências das 187 enfermeiras, segundo as respostas da questão 31 .

Tabela 19 - Distribuição de freqüências das 187 enfermeiras, segundo as respostas da questão 32

Tabela 20 - Distribuição de freqüências das 187 enfermeiras, segundo as respostas da questão 33 .

Tabela 21 - Freqüências absolutas e relativas do número de acertos nas questões 19 a 33 referentes ao conhecimento geral sobre custos

Tabela 22 - Freqüências absolutas e relativas do número de questões corretas em cada agrupamento

Tabela 23 - Freqüências absolutas e relativas do conhecimento mínimo em cada agrupamento 100

Tabela 24 - Freqüências absolutas e relativas do conhecimento geral sobre custos das 76 enfermeiras segundo os grupos de especialização 102

Tabela 25 - Freqüências absolutas e relativas do conhecimento geral sobre custos das 76 enfermeiras segundo os cargos ocupados 103

Tabela 26 - Valores descritivos da idade e dos tempos, segundo o grupo de acerto. 104

Tabela 27 - Freqüências absolutas e relativas do conhecimento geral sobre custos das 76 enfermeiras segundo os grupos de especialização 104

Tabela 28 - Freqüências absolutas e relativas do conhecimento geral sobre custos das 76 enfermeiras segundo os grupos de funções desenvolvidas 105

Tabela 29 - Valores descritivos da idade e dos tempos de formado, na instituição e no cargo nos agrupamentos de conhecimentos sobre custos 106

Tabela 30 - Distribuição de freqüências das 187 enfermeiras, segundo as respostas das questões 34 e 35 108

Tabela 31 - Distribuição de freqüências das 181 justificativas para resposta afirmativa na questão 35 . 109

Tabela 32 - Distribuição de freqüências das 144 justificativas das enfermeiras com resposta afirmativa na questão 36 
Tabela 33 - Distribuição de freqüências das 158 justificativas das enfermeiras com resposta afirmativa na questão 37

Tabela 34 - Valores descritivos da idade e gênero, segundo a instituição de estudo

Tabela 35 - Valores descritivos dos tempos de formação, de instituição e no cargo, segundo a instituição de estudo. 114

Tabela 36 - Freqüências absolutas e relativas do cargo, titulação e área de titulação, segundo a instituição de estudo

Tabela 37 - Freqüências absolutas e relativas das respostas das questões 8 a 18 , relativas às práticas gerencias de custos, segundo a instituição de estudo 116

Tabela 38 - Freqüências absolutas e relativas dos acertos das questões 19 a 33 relacionadas aos principais conceitos sobre custos, segundo a instituição de estudo 


\section{SUMÁRIO}

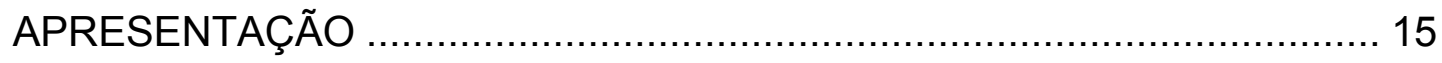

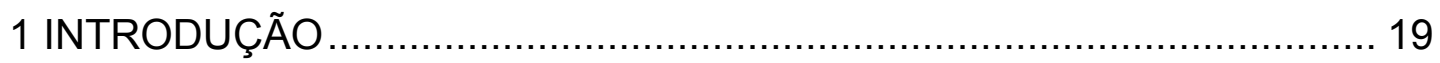

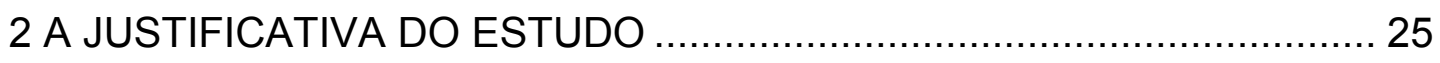

3 A CONTABILIDADE GERENCIAL E DE CUSTOS ................................ 28

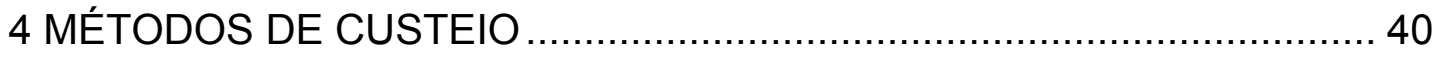

4.1 MÉTODO DE CUSTEIO POR ABSORÇÃO ………........................... 43

4.2 MÉTODO DE CUSTEIO PADRÃO ……………................................. 46

4.3 MÉTODO DE CUSTEIO VARIÁVEL OU DIRETO ……....................... 47

4.4 MÉTODO DE CUSTEIO POR ATIVIDADE: MÉTODO ABC .................. 48

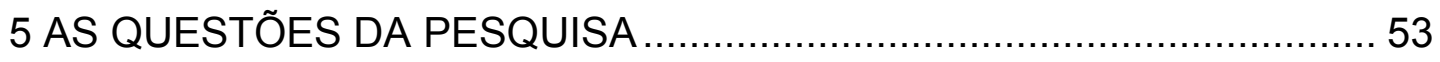

6 OBJETIVOS

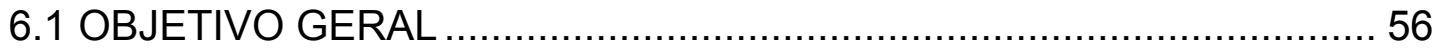

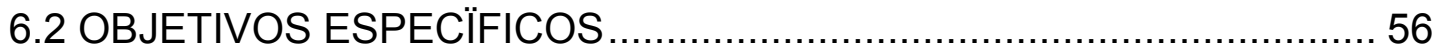

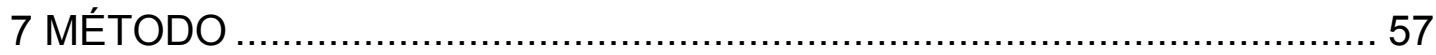

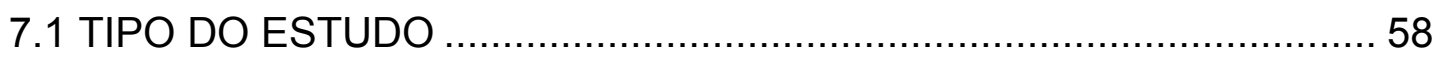

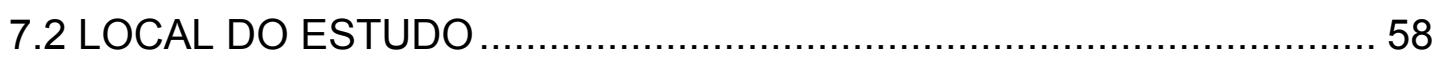

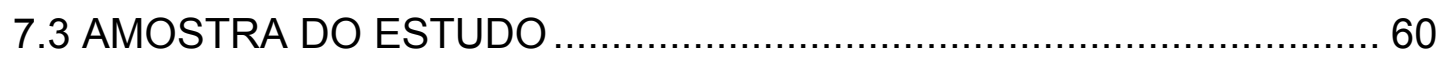

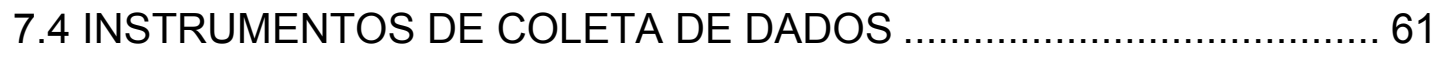

7.5 PROCEDIMENTO PARA A VALIDAÇÃO DO CONTEÚDO DO

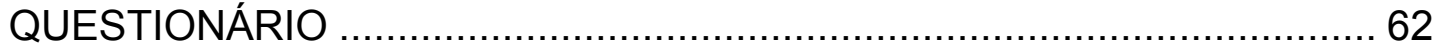

7.6 APRESENTAÇÃO E ANÁLISE DOS RESULTADOS DA VALIDAÇÃO. 65

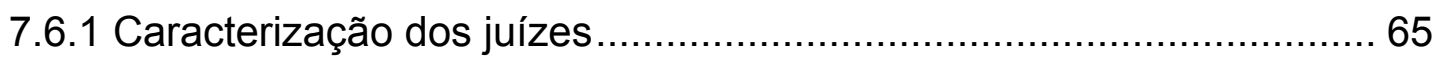

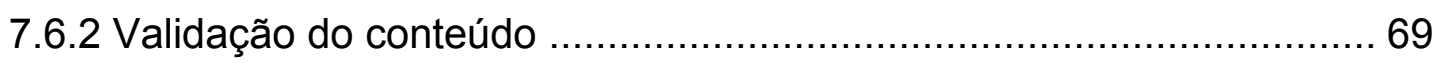

7.7 PROCEDIMENTOS PARA A COLETA DE DADOS …......................... 72

7.8 APRESENTAÇÃO E ANÁLISE DOS RESULTADOS ........................... 73

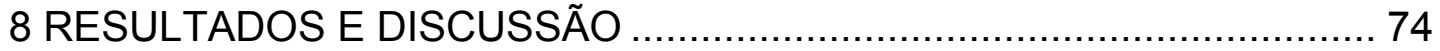

8.1 CARACTERIZAÇÃO DAS INSTITUIÇÕES DE SAÚDE E PERFIL DAS

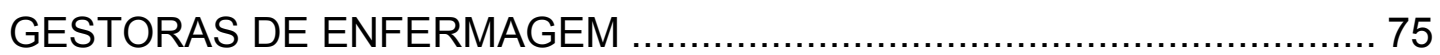

8.2 CARACTERIZAÇÃO DA AMOSTRA DO ESTUDO ……..................... 78

8.3 AVALIAÇÃO DO CONTEÚDO DAS PRÁTICAS GERENCIAIS EM CUSTOS 
8.4 CONHECIMENTO DAS ENFERMEIRAS SOBRE OS PRINCIPAIS CONCEITOS DE CUSTOS HOSPITALARES ........................................ 90 8.5 ANÁLISE DOS AGRUPAMENTOS DE QUESTÕES SOBRE CONHECIMENTO GERAL SOBRE CUSTOS ........................................ 99 8.6 A PARTICIPAÇÃO DAS ENFERMEIRAS NO GERENCIAMENTO DE

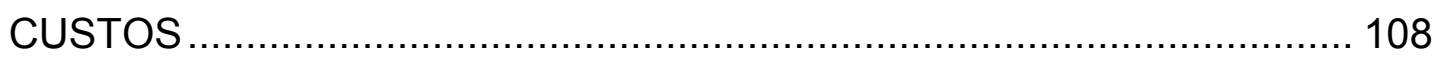

8.7 COMPARAÇÃO ENTRE AS INSTITUIÇÕES ………………............ 112

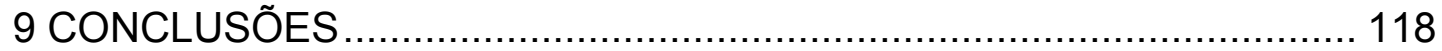

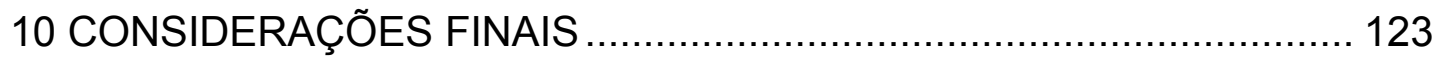

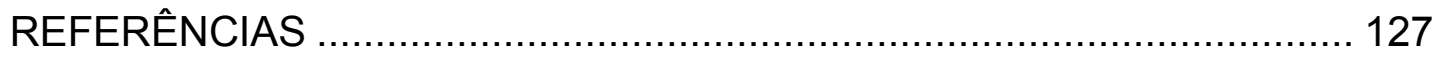

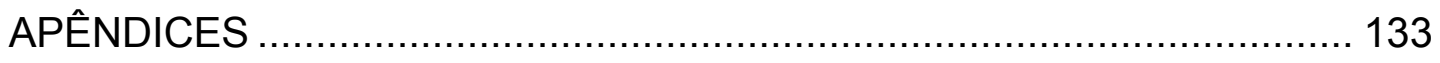

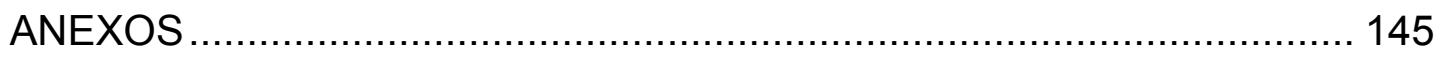


APRESENTAÇÃO 


\section{APRESENTAÇÃO}

As organizações de saúde, inseridas em um mercado competitivo, têm sido forçadas a adequar seus modelos de gestão ao atual contexto. Diante desse desafio, os hospitais, dada sua complexidade, vêm efetuando mudanças em seus sistemas administrativos com a finalidade de maximizar a utilização de recursos e orçamentos limitados, mas considerando a garantia da qualidade da assistência prestada aos pacientes.

Todos os países compartilham esta dificuldade segundo o Conselho Internacional de Enfermagem (ICN) ${ }^{(1)}$. Autores acrescentam, que a atenção à saúde não é gratuita, e sejam quais forem as fontes de financiamento, públicas ou privadas, elas absorvem recursos na forma de impostos, seguros ou gastos particulares, sendo que esses recursos não são ilimitados $^{(2)}$.

Autoras acrescentam ainda, que recursos escassos e custos crescentes afetam todos os prestadores de serviços em saúde e não só as organizações hospitalares, e que estes devem operar com mais eficiência e avaliar mais as contenções de custos. As autoras também afirmam que esta contenção de custos deva associar-se à eficaz e eficiente oferta dos serviços e ao mesmo tempo, gerar uma receita suficiente para que a produtividade da organização mantenha sua continuidade ${ }^{(3)}$.

A contenção de custos é responsabilidade de qualquer provedor de assistência à saúde e a capacidade em realizá-la acarreta na sobrevivência de muitas organizações ${ }^{(3)}$.

Nesta direção o Conselho Internacional de Enfermagem ${ }^{(1)}$ faz uma colocação referida pela Organização Mundial de Saúde em 1983, que "entre todas as profissões de atenção à saúde, a enfermagem tem maior potencial para assegurar cuidados rentáveis, ... , sua voz deve ser ouvida no debate sobre políticas rentáveis".

No contexto atual, pensamos em enfermagem como sendo uma profissão que se encontra em contínua transformação, que incorpora reflexões sobre temas emergentes, dificuldades e ações, mantendo os princípios éticos, políticos e legais ${ }^{(4)}$. 
A preocupação em estudar custos não é recente por parte das enfermeiras. Há muitos anos elas vêm se preparando para este gerenciamento devido às exigências administrativas que elas possuem em seus setores.

Nota-se que a participação das enfermeiras na gestão de custos é mais representativa quando as mesmas ocupam cargos de gerência. Com isso, elas procuram atuar em parceria com os administradores hospitalares na tentativa de conhecer melhor os gastos e os custos, minimizando-os e contribuindo para o seu controle.

Mas será que as enfermeiras possuem conhecimentos sobre custos suficientes para gerir um setor? O $\mathrm{ICN}^{(1)}$ afirma que as enfermeiras devem buscar na literatura, estudos já produzidos para avaliarem sua aplicação no cálculo e no controle de custos dos serviços de enfermagem. Reforçam a importância de conhecerem os sistemas de classificação e metodologias de aferição de custos para buscarem dados empíricos sobre a rentabilidade do seu serviço.

Depreende-se então que para a enfermeira atender às exigências relativas à profissão e as necessidades dos ambientes de trabalho, ela deve ser capacitada para gerenciar custos desde a sua graduação e, ainda, procurar agregar conhecimentos nos cursos de pós-graduação.

Desde 2004, atuando como docente da disciplina gerenciamento em enfermagem, ministrada aos alunos do penúltimo e último ano da graduação e no curso de pós-graduação em gestão em enfermagem, em uma universidade privada na cidade de São Paulo, reconheço a necessidade da discussão sobre novos modelos de gestão em saúde com enfoque em resultados, o que inclui a gestão de custos.

Minha experiência mostrou-me que apesar do assunto custos estar inserido no conteúdo programático das disciplinas de administração em enfermagem, tanto no curso de graduação quanto no curso de pósgraduação, as enfermeiras sentem-se inseguras sobre o tema e não se sentem preparadas para atuar no mercado de trabalho atual, no qual convivem com restrições financeiras e dificuldades econômicas, independente do setor ser privado ou público. 
A motivação inicial para o estudo deste tema adveio, portanto, de reflexões vivenciadas na docência e das contradições entre o que se ensina nos cursos de graduação e pós-graduação e o desenvolvimento do gerenciamento de custos propriamente dito nas organizações hospitalares.

Carrego comigo a preocupação com a formação das enfermeiras em relação aos custos, pois acredito em uma formação abrangente e atualizada que forneça subsídios ao profissional, para exercer a profissão com segurança, atendendo às exigências do mercado atual.

Muitos estudos mostram a necessidade de verificar o conhecimento das enfermeiras sobre custos, porém intensifico que não é esta a única necessidade, precisamos avaliar a participação das enfermeiras no gerenciamento de custos, sua capacitação e a sua importância nesta atividade.

Desta forma, este estudo estará ilustrando a realidade das enfermeiras de duas organizações hospitalares com relação à participação das mesmas no gerenciamento de custos, avaliando o conhecimento sobre os conceitos de custos, extremamente importante para a eficiência nesta gestão. 


\section{INTRODUÇÃO}

Em relação aos gastos, nos últimos cinco anos, os dados da Organização Mundial de Saúde, de 2006, indicam que o Brasil se posiciona entre os dez países do continente americano com maiores gastos com a saúde, valores absolutos próximos de US $\$ 37,5$ bilhões. Em média, $45 \%$ deste valor são provenientes de fontes públicas e os demais $55 \%$ de fontes privadas $^{(5)}$.

Em 2005, a assistência hospitalar foi responsável por 43,83\% dos gastos do Ministério da Saúde, valor correspondente a procedimentos de média e alta complexidade ${ }^{(5)}$.

A elevação dos gastos tem sido objeto de atenção por parte dos gestores hospitalares, profissionais de saúde e, também, das fontes pagadoras da assistência, seja o Sistema Único de Saúde (SUS), ou o Sistema Suplementar, por meio das operadoras de planos e convênios. Os custos crescem e os recursos diminuem tanto no setor público quanto no privado.

Em decorrência da conjuntura econômica nacional complexa, o setor da Saúde, no âmbito privado, tem enfrentado grandes dificuldades financeiras, sem poder repassar seus aumentos de custos automaticamente para os preços, devido, principalmente, a fatores relacionados à competitividade do mercado, à pressão da sociedade e dos Planos de Saúde, e a certo controle de preços do governo.

Por outro lado, em conseqüência da diminuição dos gastos federais, estaduais e municipais com saúde, frente ao aumento das demandas da população por serviços de saúde, os hospitais da rede pública vêm enfrentando dificuldades para gerirem seus recursos escassos.

Segundo Médici ${ }^{(6,7,8)}$, o crescimento exponencial dos gastos no setor de saúde é decorrente do envelhecimento da estrutura etária da população e aumento da expectativa de vida, do crescimento da demanda por atendimento devido à universalização do acesso à saúde, do avanço tecnológico, da escassez de mão de obra qualificada acarretando em baixa produtividade dos serviços, da falta de capacitação administrativa dos 
gerentes, da não implementação dos sistemas de controle de custos, dos desperdícios na cadeia produtiva, entre outros.

Visando a contenção de gastos sem a perda da qualidade do serviço a que se propõe prestar, a implementação de sistemas de gerenciamento de custos emerge oportunamente na área de saúde. Para isso, é necessário o envolvimento não só da área administrativa, mas também dos gerentes das diferentes unidades que compõem uma organização hospitalar, pois cada integrante deve contribuir, com seu conhecimento específico, na criação, implementação e controle desse sistema.

As organizações hospitalares têm implantado sistemas de gerenciamento de custos, que segundo Falk "é uma ferramenta gerencial para a melhoria do desempenho da organização em termos de fornecer informação necessária para a tomada de decisões objetivas, visando a contenção de gastos ou ao aumento na receita, ou ambos" (9).

O gerenciamento de custos é uma das atividades dos gestores. É uma ferramenta para descrever as ações que os gestores realizam com o intuito de satisfazer os clientes, enquanto, continuamente, reduzem e controlam os custos ${ }^{(10)}$.

Controlar ou gerenciar custos é conhecer a realidade, possibilitando assim, compará-la com o padrão estabelecido, tomando conhecimento rápido das divergências e suas origens, atuando diretamente na correção. Seus objetivos são estabelecimentos de padrões e orçamentos, comparações entre o custo real e o orçado, formação de preços, determinação da quantidade de serviços ou produtos a serem produzidos, escolha do que produzir e avaliação ou decisão sobre o que cortar em relação aos custos ${ }^{(11)}$.

Uma das ferramentas utilizadas para o controle dos custos nas organizações de saúde, assim como em outras organizações de diferentes ramos de atividade é o sistema de gerenciamento de custos, que proporciona ao gestor maior controle dos gastos da instituição e possibilita ainda delineamento nas tomadas de decisão.

Assim, as preocupações dos gestores da saúde têm se voltado para apuração e controle dos custos hospitalares e, também para medidas de 
contenção de custos. Destaca-se, principalmente, a responsabilidade das enfermeiras nesse processo, enquanto gerentes de unidades hospitalares, responsáveis pela alocação de recursos para os diferentes processos assistenciais.

Devido às dificuldades financeiras enfrentadas pelas instituições de saúde, os gestores têm sido obrigados a olharem e controlarem com mais atenção seus custos, sob o sério risco de ficarem deficitários e inviáveis ${ }^{(12)}$.

Essa exigência trouxe aos gerentes e profissionais de saúde a necessidade de aquisição de conhecimentos sobre custos, a busca de medidas para equilibrá-los com os recursos financeiros, a competência na alocação de recursos e a otimização de resultados ${ }^{(12)}$.

Hoje, ainda se observa na maioria das organizações de saúde a inexistência de informações sobre custos devido à participação neste processo ser, na maioria das vezes, realizada somente por profissionais da área contábil-financeira e da administração. Entretanto, há necessidade da disseminação dessas informações para todos os colaboradores de uma empresa, permitindo assim o conhecimento e a análise tanto pela gerência de cada setor quanto para os demais envolvidos nesses processos.

Há uma necessidade ímpar de aprimoramento de conhecimentos na gestão em custos e nos sistemas de informação destes custos hospitalares devido às enfermeiras terem assumido um papel de extrema importância no contexto hospitalar ${ }^{(13)}$.

Considerando todos os fatores acima mencionados e aproximando-os para o ambiente hospitalar, percebe-se a importância do gerenciamento dos recursos e processos de trabalho com a finalidade de melhorar a gestão da qualidade e, conseqüentemente, dos custos, principalmente, nas organizações hospitalares. Para isso, há necessidade de identificá-los com a finalidade de propor ações que possam minimizá-los.

Os profissionais que gerenciam as unidades hospitalares - médicos, enfermeiras, nutricionistas, farmacêuticos, entre outros, devem desenvolver conhecimento que os auxilie nas tomadas de decisão para alocação de recursos, pois estes são geradores de custos nas organizações hospitalares. Para isso, devem determinar quais recursos são necessários para o nível de 
produção de atividades assistenciais ou de apoio da sua unidade, considerando não apenas os aspectos quantitativos e qualitativos, mas o impacto dos aspectos financeiros.

O ICN, desde 1993, manifestou que custos é uma área de domínio das enfermeiras e que elas devem estar preparadas para apresentar o valor e a rentabilidade de sua assistência, utilizando argumentos para a obtenção de recursos. Incentivava ainda, que as enfermeiras desenvolvessem estudos de metodologias de mensuração de custos nos serviços de enfermagem, estudos estes que até hoje, encontramos em quantidades inferiores aos estudos de outras áreas de conhecimento da enfermagem ${ }^{(1)}$.

O ICN recomendou às associações filiadas que oferecessem às enfermeiras oportunidades educativas para aquisição de conhecimentos financeiros, estimulando a formação administrativa e incentivando a participação delas no desenvolvimento de estudos na área de custos ${ }^{(1)}$.

Assim, as enfermeiras têm controlado, ou tentado controlar, seus custos através de planilhas geradas pelos sistemas de custos, recebidas dos serviços de contabilidade. Por mais completo e elaborado que seja um sistema de custeio, há necessidade de a enfermeira utilizar outras ferramentas que colaboram com o entendimento destes sistemas.

"Custos hospitalares é um instrumento fundamental para a otimização das operações do hospital", e, além disso, podem auxiliar na determinação dos preços de venda, nas tomadas de decisão(11).

Outras ferramentas gerenciais que as enfermeiras têm utilizado, relacionadas ao gerenciamento dos custos, são o orçamento e a auditoria contábil. Elas têm participado do planejamento orçamentário bem como acompanhado a sua execução, pela análise contínua dos valores orçados e os valores incorridos. Orçamento pode ser entendido como a grande arma global de controle de uma empresa ${ }^{(11)}$.

A participação das enfermeiras nas auditorias contábeis internas em alguns hospitais tem a finalidade de minimizar as perdas de seu faturamento. As atividades realizadas são de pré-análise das contas, apontando o grupo contábil que está gerando perdas e promovendo medidas para a sua correção(14). 
Assim, as enfermeiras têm desenvolvido diferentes atividades relacionadas a essas ferramentas da área financeira e contábil, ora se preparando formalmente, através da participação em cursos específicos, ora aprendendo com a prática gerencial.

Autores ao avaliarem o conhecimento das enfermeiras, em relação aos conceitos de custos hospitalares, enquanto gestores de enfermagem em hospitais com metodologia implantada de apuração de custos demonstram que ele é baixo, o que dificulta a utilização dessa ferramenta ${ }^{(15)}$. No entanto, a enfermeira, por atuar 24 horas na assistência, é um elemento importante no controle e análise de custos em decorrência do seu envolvimento em diferentes processos de trabalho, por conhecer as necessidades e características dos pacientes e dos recursos para seu atendimento.

Acredita-se ser a enfermeira, a profissional que reúne maior número de informações e condições para atuar na gestão de custos, participando na elaboração, apuração e análise dos custos dos processos e procedimentos da assistência de enfermagem ${ }^{(15)}$.

A enfermeira, consciente da multiplicidade de papéis que desenvolve na organização hospitalar, deve estar preparada para avaliar, processar e integrar as informações do hospital para realizar um trabalho lucrativo assim como reformular ou criar medidas administrativas que contribuem para o desenvolvimento de ações efetivas ${ }^{(16,17)}$.

O questionamento que se faz é: diante de todas as afirmações sobre as melhores condições de atuação da enfermeira decorrente de sua formação, será que estas estão preparadas para administrar custos? Será que estão dispostas a assumir as ações relacionadas à gerência de custos? Será que estas acreditam que administrar custos é um dos papéis da enfermeira? As instituições oferecem às enfermeiras a estrutura adequada para desenvolver o gerenciamento de custos? Essas questões norteiam a realização do presente estudo. 


\section{A JUSTIFICATIVA DO ESTUDO}

A participação das enfermeiras na contenção de custos é uma realidade não só no Brasil como em outros países do mundo. Estudo norte americano apontou que, em 1989, 53,4\% das equipes de enfermagem já estavam envolvidas com alguma atividade de análise ou contenção de custos $^{(18)}$.

A enfermeira, conforme citado anteriormente, é apontada como a profissional mais capacitada para a realização deste gerenciamento, pois possui domínio dos conhecimentos específicos da assistência de enfermagem, coordena todas as atividades realizadas aos pacientes e aloca recursos para seu desenvolvimento. É também, membro integrante do grupo de profissionais que estuda desde a graduação o gerenciamento de custos e pode com isto, aprofundar seus conhecimentos na área e atuar com segurança no gerenciamento.

Diante disto, percebe-se a importância da participação da enfermeira no gerenciamento de custos hospitalares sendo ela uma das grandes responsáveis pelo faturamento e rentabilidade da assistência ${ }^{(19)}$.

Assim, as instituições de saúde vêm se preocupando com a capacitação dos seus profissionais tanto na área da assistência, para elevar o padrão de qualidade, quanto na área administrativa, gerenciando melhor os setores, o faturamento, os custos e, conseqüentemente, os rendimentos.

Entretanto, estudos realizados entre 2002 e 2007, mostraram que as enfermeiras não se sentem preparadas para tal função ${ }^{(15,20)}$.

Ressalta-se, ainda, que a temática "custos em saúde e em enfermagem" é emergente, havendo muito pouco conhecimento desenvolvido, principalmente, na realidade brasileira.

Outro aspecto, que tem surgido nas discussões com outras enfermeiras, membros de um grupo de pesquisa sobre gerenciamento de custos em organizações de saúde, é que as docentes enfermeiras do curso de graduação em enfermagem não possuem conhecimento específico sobre custos e que há uma dificuldade em adequar o perfil de competências gerenciais em custos com o ensino em enfermagem. 
Assim, há evidências empíricas da falta de conhecimento sobre custos por parte das enfermeiras, somada à necessidade de capacitação para conhecer, identificar e utilizar as ferramentas disponíveis que auxiliam no gerenciamento de custos. As enfermeiras precisam adquirir subsídios que permitam a compreensão dos dados enviados nas planilhas, relatórios e no próprio orçamento para que transformem estes dados em informações importantes nos processos de tomada de decisões.

Diante de tais questionamentos a hipótese é que hoje, mesmo com alguns estudos de custos na área da enfermagem, as enfermeiras não possuem conhecimentos suficientes nesta área que possibilitam 0 embasamento para a atuação no gerenciamento de custos. Elas não se sentem preparadas para assumir este ramo do gerenciamento uma vez que, não possuem apoio da organização onde atuam ou não têm acesso aos dados e informações necessários para atuar na gestão de custos. As enfermeiras, diante de várias ferramentas que auxiliam neste gerenciamento, não sabem como utilizá-las.

Assim, pretende-se que os resultados dessa pesquisa forneçam informações importantes para um maior conhecimento sobre como vêm sendo essa participação das enfermeiras, quais as ferramentas de gerenciamento de custos têm sido utilizadas e quais são os resultados que essa prática tem trazido para o gerenciamento dos serviços de enfermagem. Esses resultados também subsidiarão as propostas de novas pesquisas e no ensino dessa temática, tanto nos cursos de graduação quanto de pósgraduação senso lato e stricto. 


\section{A CONTABILIDADE GERENCIAL E DE CUSTOS}

A ciência que estuda os fatos contábeis medindo, avaliando e interpretando as informações para os administradores de empresa é chamada de contabilidade ${ }^{(21)}$.

Por outro lado, outro autor conceitua contabilidade como "instrumento que fornece o máximo de informações para a tomada de decisão dentro e fora da empresa". E ainda refere que o emprego da contabilidade não deve ter somente o objetivo fiscal, mas sim, a elaboração de relatórios com registro das movimentações monetárias que permitem a análise dos resultados obtidos ${ }^{(22)}$.

A contabilidade originou-se na Antiguidade, embora nesta época, as informações históricas não eram tão apuradas quanto o desejável. Os dados referem que nesta época, cerca de 2000 anos antes da era cristã, o povo chinês já utilizava sistemas contábeis, orçamentos e auditoria, para gerenciar as atividades do governo e ainda no Egito e na Grécia, estes sistemas eram utilizados na administração pública ${ }^{(23)}$.

Da época romana poucos registros foram encontrados sobre o uso da contabilidade, pois este povo utilizava placas de cera para registrar os dados contábeis, e evidentemente não resistiram ao tempo, por isso não foram encontradas. A evolução veio no século $\mathrm{XV}$, com a gradativa expansão da atividade comercial e os sistemas econômicos caracterizavam-se pela autosuficiência das unidades feudais com volume reduzido de negociações entre as diversas comunidades ${ }^{(23)}$.

No século XVIII, época da Revolução Industrial, somente era conhecida a contabilidade financeira ou geral, que atendia as empresas comerciais, na era mercantilista. O desenvolvimento da contabilidade dependeu da evolução de alguns conceitos do sistema capitalista, entre eles, moeda, crédito, comércio e capital para produção.

Para o cálculo do valor, bastava somente a apuração dos estoques em termos físicos, uma vez que a medida monetária era simples, o profissional responsável pela contabilidade, o contador, verificava o 
montante pago por cada item estocado e assim sendo, projetava valores às mercadorias para que ocorresse um balanço inicial positivo entre $o$ recebimento e o pagamento, valorizando as mercadorias e determinando o lucro bruto, que deduzindo as despesas, gera o lucro líquido ${ }^{(11)}$.

A demonstração de resultados descrita acima é utilizada ainda hoje em muitas organizações de diferentes ramos de atuação, pois apresenta claramente o balanço inicial das mesmas.

Um dos instrumentos da administração de controle de procedimentos empresariais é a contabilidade financeira que agrega um conjunto de bens, direitos, obrigações e capital próprio. Ainda apresenta a relação das operações financeiras e suas conseqüências no patrimônio líquido da empresa $^{(24)}$.

Nos ramos comerciais, havia facilidade na identificação do valor das compras dos bens, pois os mesmos eram verificados nos documentos que comprovavam as aquisições.

Hoje, com o incremento industrial, a determinação do valor dos bens não é identificada tão facilmente, pois estão incluídos neste valor, os valores pagos pela produção e mão-de-obra além de outros utilizados para tal produção.

Assim, o contador deixa de ter um valor monetário simples e passa então a somar valores agregados às mercadorias, entre eles os valores de produção.

As informações contábeis auxiliam as organizações no alcance de objetivos e metas, respondendo às questões de registro, de direção, de atenção e de solução de problemas ${ }^{(25)}$.

Devido ao crescimento das empresas a contabilidade de custos começou a ser vista como uma eficiente forma de auxiliar no desempenho das indústrias com suas novas missões, a fiscal e societária e a gerencial, e não somente na missão administrativa.

A primeira missão, fiscal e societária, está relacionada às exigências legais e fiscais e segundo alguns autores toda empresa de qualquer natureza deve manter uma contabilidade dos custos integrada com as outras escriturações mercantis ${ }^{(26)}$. 
A contabilidade gerencial tem por objetivos "a apuração do custo dos produtos, serviços e departamentos com a finalidade de controlar os custos da produção; melhorar os processos e eliminar desperdícios" e ainda auxilia nas tomadas de decisões gerenciais e no alcance dos resultados ${ }^{(27)}$. Dessa forma a contabilidade de custos integra a contabilidade gerencial, ou seja, um sistema cujo objetivo é gerar informações à administração das empresas.

A primeira finalidade da contabilidade de custos, a de mensurar monetariamente os estoques, foi sendo substituída lentamente por sua eficiente forma de auxílio no desempenho da missão gerencial, daí o nome contabilidade gerencial. Autores acrescentam que a contabilidade de custos tem duas funções relevantes nesse novo campo, o gerencial: o auxílio ao controle e a ajuda às tomadas de decisão ${ }^{(28,29)}$.

Referindo-se ao controle, sua função principal é fornecer dados para o estabelecimento de padrões, orçamentos e outras formas de previsão acompanhando efetivamente o acontecido comparando-o com os valores anteriormente definidos ${ }^{(11)}$.

Por controle de custos se entende "conhecer dada realidade, compará-la, com algo que se esperava analisar, às possíveis diferenças, identificar as causas e, se possível, tomar decisões com vistas a eliminar ou reduzir tais diferenças" ${ }^{(26)}$.

No que se refere à solução de problemas, a contabilidade de custos auxilia na resolução dos mesmos relacionados ao preço de venda, à contribuição de cada produto para o lucro da empresa, ao preço mínimo de determinado produto em situações ditas como especiais, ao nível mínimo de atividades exigido para que o negócio seja viável e ao próprio gerenciamento de custos ${ }^{(29)}$.

Por ser a contabilidade uma das ferramentas da gestão econômica e financeira das empresas, pode ser entendida como a quantidade de recursos consumidos e a quantidade física de produtos ou serviços gerados e submetidos a uma valorização econômica. Entende-se por recursos consumidos os custos e por serviços gerados e produtos, as receitas ${ }^{(30)}$. 
Os objetivos da contabilidade de custos são: estabelecimento de padrões e orçamentos, comparações entre o custo real e o orçado, determinação dos custos os insumos aplicados na produção, formação de preços, determinação dos custos das diversas áreas que compõem a empresa, controle de operações e atividades, determinação de quantidades de serviços ou produtos a serem produzidos, a escolha do que produzir e avaliação ou decisão sobre o que cortar em relação aos custos, políticas de redução de desperdício de material, tempo ocioso, elaboração de orçamentos $^{(11,29)}$.

Os conhecimentos da contabilidade de custos são cada vez mais importantes e essenciais para os gestores das organizações de saúde, pois permitem a compreensão das informações e análise dos custos para tomada de decisão e para o planejamento e controle de recursos de produção.

Em resumo, a contabilidade de custos passou de auxiliar na avaliação dos estoques para uma contabilidade com foco gerencial no controle e nas tomadas de decisão ${ }^{(11)}$.

O sistema contábil permite apuração, análise e controle adequado dos custos de produção de produtos e serviços além de constante preocupação dos gestores das organizações com relação às oscilações do perfeito gerenciamento de ganhos, custos e despesas, pois na realidade empresarial é imprescindível este perfeito gerenciamento ${ }^{(26)}$.

Para melhor compreensão dos termos técnicos relacionados à contabilidade de custos e que serão utilizados durante a discussão deste estudo, apresento a seguir as definições de cada termo.

Gasto é definido como sendo o consumo de bens e serviços por meio de desembolso imediato ou futuro. São os compromissos assumidos pela empresa na aquisição de recursos que serão consumidos na produção de produtos ou na realização de serviços ${ }^{(29)}$.

Martins corrobora com este conceito e acrescenta que gasto representa "o sacrifício financeiro com que a entidade arca para a obtenção de um produto ou serviço qualquer, sacrifício esse apresentado por entrega ou promessa de entrega de ativos (normalmente dinheiro)" (11). Exemplos de 
gastos: gasto com a compra de matéria prima, gastos com pessoal, gastos com mobiliários, etc.

O termo custo refere-se aos gastos realizados na produção de bens ou serviços fins da organização, correspondem à parcela dos gastos relativos aos bens e serviços (recursos) consumidos na produção de outros bens e serviços, conseqüentemente, todos os gastos incorridos na produção são classificados como custos ${ }^{(26)}$.

Custo também pode ser definido como "o gasto relativo à bem ou serviço utilizado na produção de outros bens ou serviços" ou os valores dos insumos utilizados na prestação de serviços ${ }^{(11)}$. Exemplos de custos são: a matéria prima que foi gasta para a elaboração de um bem ou serviço, mão de obra diretamente consumida na produção, os custos gerais de produção como água, energia elétrica, depreciação entre outros.

Numa definição econômica do negócio, entende-se também por custo "quantidade de dinheiro necessária ou requerida para obter o uso de um dado recurso". O autor ainda coloca que as definições sobre custos relacionam-se também com o conhecimento dos indivíduos e conclui que não existe custo verdadeiro ${ }^{(9)}$.

Custos hospitalares são "todos os valores que direta ou indiretamente convertemos na compra de bens e serviços, para dar suporte à atividade médica, no tratamento das patologias que afligem o paciente", ou seja, todos os gastos utilizados no processo de produção de serviços. O autor complementa que custos hospitalares "devem ser compreendidos como um poderoso sistema de informações contábeis, e principalmente gerenciais, para avaliarmos o desempenho, produtividade e qualidade de todos os serviços oferecidos à comunidade" *

Outro autor acrescenta que custo hospitalar é definido como um fundamental instrumento para otimização das operações no hospital, possibilitando correção para qualquer resultado percebido; auxilia também

\footnotetext{
"Borin Filho H. Custos e desempenho hospitalar [Apostila do curso de especialização CenaHosp]. São Paulo; 1996.
} 
na determinação de preço de venda, possibilitando tomadas de decisão mais apuradas e concisas.

Despesas são gastos relativos aos bens e serviços consumidos no processo de geração de receita e manutenção dos negócios da empresa ${ }^{(11)}$.

Perdas são gastos anormais ou involuntários que ocorrem durante o processo de produção e que não geram um novo bem, serviço ou receita. Normalmente são eventos não previstos pelos gestores das organizações, porém são necessários muitas vezes para o aprendizado como o caso das instituições de saúde-escola. A perda não necessariamente precisa ser física(26).

Desperdícios são classificados como gastos incorridos nos processos de produção ou geração de receita e que sua eliminação acontece sem prejuízos na qualidade dos bens, serviços ou receitas geradas $^{(26)}$.

Investimentos correspondem à parcela dos gastos ativados em função da vida útil ou de benefícios atribuíveis a futuro(s) períodos, são as aquisições de bens ou serviços (gastos) que são alocados nos ativos da empresa para baixa ou amortização quando da sua venda, de seu consumo, de seu desaparecimento ou de sua desvalorização. Podem estar associados às melhorias empresariais com retorno indireto em longo prazo ${ }^{(28)}$.

É importante conhecer as definições sobre centros de custos antes de aprofundarmos os estudos nos custos propriamente ditos. Centro de custos (CC) "é a menor unidade de acumulação de custos" (26).

Centro de custos são departamentos, setores, seções, unidades ou pontos de referência que, por sistemática própria, acumulam gastos com a finalidade de determinar custos totais e/ou os custos da unidade do bem ou serviço produzido ou fornecido ${ }^{(31)}$.

O autor ainda conceitua centro de custos produtivo (CCP) como "centro de custos por onde os produtos passam durante o processo de fabricação e nos quais são transformados ou beneficiados" (31).

Autores contribuem com o conceito e colocam que são aqueles setores que desenvolvem atividades diretamente relacionadas com a 
consecução dos objetivos finais da unidade, com valores de receitas para a venda de serviços junto a clientes e instituições. Exemplos são: Unidades de Internação, Pediatria, Centro Cirúrgico, Pronto Socorro, etc ${ }^{(32) .}$

Ainda como partes do processo têm-se os centros de custos auxiliares ou administrativos (CCA), aqueles centros de custos que não atuam diretamente nos produtos, ou seja, prestam serviços ou dão apoio aos CCPs. São aqueles cujas atividades nem sempre são específicas do setor saúde, que produzem bens ou serviços consumidos por todos ou quase todos os CC de um estabelecimento de saúde e tem como objetivo prover serviços operacionais de apoio aos CCPs. Exemplos: setor de manutenção, Central de Material Esterilizado, Faturamento, Telefonia, Administração, Biblioteca, Compras, Farmácia, Serviço de Engenharia ${ }^{(26)}$.

Os custos são classificados quanto a sua apropriação aos produtos e serviços como diretos e indiretos.

Os custos diretos são aqueles custos apropriados aos produtos conforme o consumo ${ }^{(29)}$. Podem ser diretamente identificados ou especificados por um produto ou departamento com facilidade. Compõe-se basicamente de mão-de-obra, insumos, equipamentos, utilizados diretamente no processo produtivo, ou seja, no processo assistencial para as organizações de saúde ${ }^{(11,33)}$.

Mão-de-obra direta é o trabalho ou esforço aplicado diretamente na realização de um serviço, procedimento ou produto e o autor coloca também que o custo da mão-de-obra compõe-se dos salários, encargos sociais e provisões para férias e $13^{\circ}$ salário $^{(11)}$. Como exemplo, temos a mão-de-obra direta de um enfermeira na realização de uma passagem de sonda vesical em um paciente.

Custos indiretos são aqueles não caracterizados por um centro de custos específico, ou seja, são custos comuns a diversos procedimentos e serviços, não podendo ser mensurados individualmente, neste caso, sua apropriação ${ }^{(11)}$. Exemplos são: energia elétrica, água, seguros contra incêndios entre outros. Por não serem perfeitamente indicados nos produtos, processos ou centros de custo, os custos indiretos não podem ser 
apropriados diretamente para unidades específicas e por isso necessitam de algum critério de rateio para a sua apropriação ${ }^{(26,29)}$.

Materiais indiretos são aqueles que não possuem ligação direta com as atividades, seu relacionamento é irrelevante para o custo do produto ${ }^{(11)}$.

Mão-de-obra indireta é ilustrada pelo trabalho realizado nos serviços e setores/departamentos e que não são mensuráveis em nenhum procedimento, processo ou produto ${ }^{(11)}$. Como exemplo, temos a mão-deobra do enfermeira consumida no gerenciamento da unidade onde o procedimento de sondagem vesical foi realizado.

Nos custos indiretos, a base de rateio deve ser uma relação próxima entre o custo indireto e o produto ou serviço. Geralmente, são utilizados critérios subjetivos e arbitrários para as bases de rateio que podem provocar distorções nos resultados finais. Exemplos dos critérios são períodos (horas) de mão-de-obra, períodos (horas) de utilização de equipamentos, quantidade (quilos) de matéria-prima consumida ${ }^{(29)}$.

Esses critérios de rateio consistem na determinação para a distribuição dos custos indiretos e dos centros de custos auxiliares e administrativos a fim de gerar um custo final do serviço.

Exemplos dos critérios de rateio para os custos indiretos podem ser visualizados na Figura 1, abaixo.

\begin{tabular}{|l|l|}
\hline \multicolumn{1}{|c|}{ Custos Indiretos } & \multicolumn{1}{c|}{ Critérios de rateio } \\
\hline Aluguel & Área ocupada $\left(\mathrm{m}^{2}\right)$ \\
\hline Depreciação & Área ocupada $\left(\mathrm{m}^{2}\right)$ \\
\hline Seguros & Área ocupada $\left(\mathrm{m}^{2}\right)$ \\
\hline Energia Elétrica & Consumo de energia $(\%)$ \\
\hline Água & Consumo de água $(\%)$ \\
\hline Telefone & Número de ramais \\
\hline Impostos e Taxas & Área ocupada $\left(\mathrm{m}^{2}\right)$ \\
\hline Outros custos e despesas & Número de funcionários \\
\hline
\end{tabular}

Figura 1 - Critérios de rateio para custos indiretos, São Paulo - 2002

Fonte: Matos AJ de. Gestão de custos hospitalares, São Paulo - 2002 
Exemplos dos critérios de rateio para os centros de custos auxiliares e administrativos podem ser visualizados na Figura 2, abaixo.

\begin{tabular}{|l|l|}
\hline \multicolumn{1}{|c|}{ CCAs } & \multicolumn{1}{c|}{ Critérios de rateio } \\
\hline Serviço de nutrição e dietética & Número de refeições $\left(^{\dagger}\right)$ \\
\hline Lavanderia & Quilos de roupa \\
\hline Central de Material Esterilizado & Volumes processados $\left.{ }^{* *}\right)$ \\
\hline Limpeza & Área ocupada $\left(\mathrm{m}^{2}\right)$ \\
\hline Almoxarifado & Número de requisições \\
\hline Manutenção & Horas de manutenção \\
\hline Same & Estatística de produção \\
\hline Faturamento & Faturamento $(\%)$ \\
\hline Contabilidade & Custos diretos $(\%)$ \\
\hline Departamento Pessoal & Número de funcionários \\
\hline Administração Geral & Número de funcionários \\
\hline
\end{tabular}

Figura 2 - Critérios de rateio para centros de custos auxiliares e administrativos, São Paulo - 2002

Fonte: Matos AJ de. Gestão de custos hospitalares, São Paulo - 2002

Os custos totais podem ser divididos em fixos e variáveis além da classificação em diretos e indiretos. Esta classificação refere o comportamento do custo em relação ao volume de produção, ou seja, considera a relação entre o valor total de um custo e o volume de atividade numa unidade de tempo ${ }^{(9)}$.

Segundo autores os custos fixos, aqueles que permanecem constantes, independentemente do volume de produção/atendimento modificar para mais ou para menos, não alteram o valor total do custo. A característica principal desses custos é a constante que o valor total apresenta numa determinada faixa de produção. Exemplos: custos administrativos, salários, aluguel, seguro, IPTU, etc ${ }^{(11,34)}$.

Outros autores complementam este conceito e caracterizam custos fixos como aqueles que decorrem da manutenção da estrutura produtiva da empresa, independente da quantidade que de fabricação dentro do limite da capacidade instalada ${ }^{(29)}$.

\footnotetext{
* Para o rateio desses centros de custos recomenda-se a metodologia de unidades equivalentes (Matos, 2005)
} 
Estes custos também necessitam de alguma base de rateio para serem alocados em serviços ou setores/departamentos.

Já os custos variáveis, mantêm relação direta com a produção, ou seja, crescem à medida que o volume de atividades aumenta ${ }^{(34,35)}$. A característica destes custos é que o valor permanece constante por unidade e o direcionamento destes custos é realizado de forma direta, não há necessidade de utilização de bases de rateio. Exemplos: materiais de consumo, medicamentos, filmes radiológicos, lavanderia, etc ${ }^{(29)}$.

Há uma terceira denominação que são os custos semifixos, são aqueles elementos dos custos classificados como fixos, mas que alteram em decorrência de mudança na capacidade de produção ${ }^{(29)}$. Exemplo deste custo é a capacidade de ocupação de um setor que apresenta mão-de-obra fixa até sua capacidade máxima, mas caso ocorra uma elevação desta capacidade máxima com leitos extras, há necessidade de utilizar horas extras de funcionários para determinados períodos.

O autor ainda classifica custos em semivariáveis, aqueles custos que possuem em seu valor uma parte fixa e outra variável, ou seja, possuem comportamento de custo fixo até certo ponto e em seguida se comportam como custo variável. Exemplos são a energia elétrica e a água ${ }^{(29)}$.

Todos os custos podem ser ao mesmo tempo classificados como diretos ou indiretos e fixos ou variáveis. Assim, um determinado custo pode ser direto e fixo e outro indireto e variável.

A Figura 3 abaixo esboça um resumo da classificação dos gastos. 


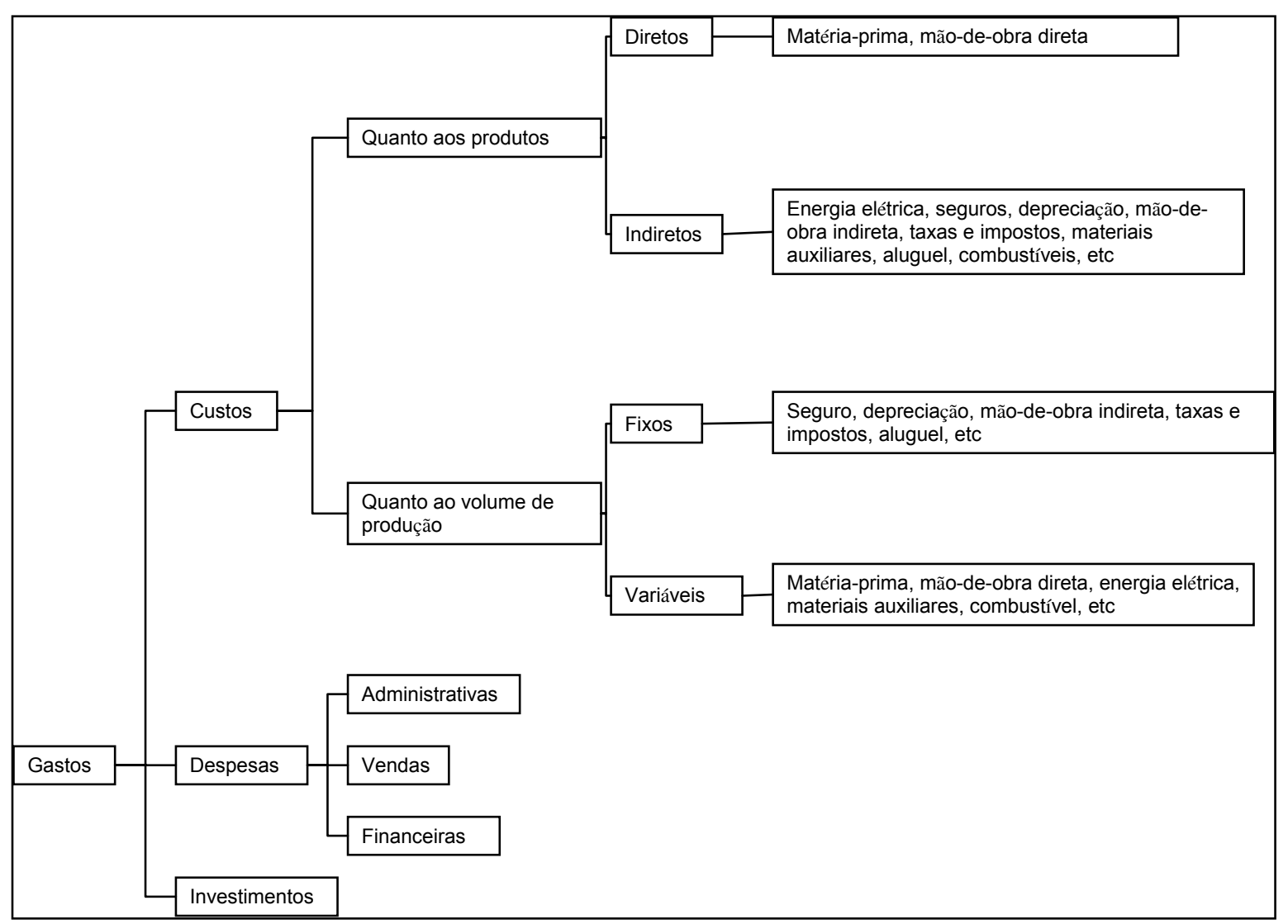

Figura 3 - Resumo da classificação de gastos, São Paulo - 2007

Fonte: Megliorini E. Custos: análise de gestão, São Paulo - 2007

Com o conhecimento de todos estes conceitos sobre custos e contabilidade fica explícito que hoje, a contabilidade gerencial é um instrumento vital de conhecimento de todos os envolvidos numa organização que possuam interesses pela produtividade e lucro empresarial.

Há necessidade da enfermeira enquanto gerente de uma unidade hospitalar possuir conhecimento sobre custos, contabilidade gerencial e métodos de apuração de custos para melhor desempenho das atividades relacionadas ao gerenciamento de custos e ao atendimento das necessidades das organizações de saúde.

No próximo capítulo serão abordados conceitos sobre os métodos de custeio mais utilizados na prática gerencial em organizações de saúde. 


\section{MÉTODOS DE CUSTEIO}

Apropriação de custos ou métodos de custeio pode ser definido como "a determinação por sistemática própria dos gastos realizados com a produção das unidades de bens e de serviços produzidos e/ou fornecidos"(31).

Os métodos de custeio são utilizados para a apuração de custos, métodos estes que determinam a forma de valorização dos objetos de custeio, que podem ser de uma atividade, um procedimento, um processo, um produto ou um serviço ${ }^{(29)}$.

Segundo Beulk e Bertó, entende-se por sistema de custeio "o conjunto de procedimentos adotados numa empresa para calcular algo, ou seja, os bens ou serviços nela processados" (16).

A apropriação dos custos é definida como custeio e entende-se por sistema de custeio a forma de cálculo dos custos ou da apropriação dos custos aos produtos ou serviços. Portanto, com a utilização de métodos de custeio é possível determinar como será o valor dos objetos de custo, ou seja, tudo aquilo que se pretende custear ${ }^{(28)}$.

Qualquer método de custeio tem como objetivo principal determinar o custo incorrido no processo de produção de bens ou serviços, fornecendo informações sobre os gastos na estrutura organizacional das empresas, permitindo a identificação dos responsáveis pelos gastos e conseqüentemente facilitando a elaboração de orçamentos e controle gerencial $^{(26)}$.

Outros autores complementam a definição acima e incluem que o principal objetivo de um método de custeio é medir os custos dos recursos consumidos para a realização das atividades e com isso, acompanhar as informações dos custos para efeitos gerenciais ${ }^{(36)}$.

Nessa linha de raciocínio, outros autores afirmam que ainda como objetivo de um método de custeio tem a mensuração dos custos dos recursos consumidos quando são realizadas as atividades significativas para 
a empresa, suprindo informações sobre os seus custos, passíveis de acompanhamento para efeitos gerenciais.

Para que um método de custeio seja implementado, é importante que todos os profissionais envolvidos no processo tenham conscientização dos níveis de responsabilidade.

Contudo, alguns autores observam que a maioria dos profissionais de saúde tende ao afastamento dos processos administrativos e ainda justificam que a idéia de controlar custos na assistência pode reduzir os recursos ou até apresentar como conseqüência a perda da qualidade ${ }^{(20)}$.

A preocupação com os custos faz com que haja sempre a procura de novas metodologias para a apuração, análise e gestão dessa área ${ }^{(27)}$.

Os métodos tradicionais de apuração de custos são: por absorção, padrão, variável ou direto e o mais recente em utilização, o custeio baseado em atividades (Activity Bsed Costing- $A B C$ ), que se associa às modernas técnicas de gerenciamento ${ }^{(9,11)}$.

Estes métodos não são excludentes podendo ser adotados dependendo do objeto que se queira custear, possibilitando a associação harmoniosa entre vários deles, e cada qual com informações específicas às funções de uma instituição de saúde.

Muitas dificuldades são enfrentadas pelos profissionais da saúde durante o processo de implementação de uma metodologia de custeio e a geração de informações relevantes ao processo de gestão. Tais fatos correspondem a fatores de naturezas diversas, tendo como elemento fundamental para o sucesso, o fator humano ${ }^{(37)}$.

No setor saúde e nos hospitais, os objetivos de um sistema de custeio, segundo a American Hospital Association (AHA) apud Falk ${ }^{(9)}$, devem contemplar os seguintes componentes:

- Uma base comum para comunicação, negociação e planejamento entre hospitais e instituições reguladoras;

- Uma metodologia de medição dos efeitos de alterações de intensidade e diversidade dos casos atendidos; 
- Um método de avaliação e medição de desempenho contra um plano prefixado;

- Uma forma de prover informações necessárias para a gerência eficiente de recursos de todos os níveis;

- Um método para facilitar identificação de gastos que podem ser transformados de fixos para variáveis;

- Um método de identificar funções ineficientes e demonstrar qual a natureza do problema em termos de preço, volume ou prática organizacional.

Os sistemas de custeios precisam sempre considerar a qualidade da equipe de profissionais envolvidos na alimentação e processamentos dos $\operatorname{dados}^{(11)}$.

A implementação de um método de custeio é uma ferramenta importante para a gestão eficiente dos hospitais, devido à geração de informações relevantes. No entanto o fator humano é fundamental para a sua operacionalização e utilização, uma vez que as instituições de saúde estão inseridas no contexto atual de elevação de custos com recursos escassos, associado à pressão por qualidade de serviço.

A seguir serão apresentados os métodos de custeio mais utilizados nas organizações de saúde.

\subsection{MÉTODO DE CUSTEIO POR ABSORÇÃO}

Conceituado como um instrumento tradicional na gestão de custos, no método de custeio por absorção procura-se identificar as unidades independentes de produção, ou seja, centros de custos e todos os custos de produção (diretos, indiretos, fixos e variáveis) são alocados aos custos dos produtos e serviços da organização ${ }^{(28)}$.

É o método que apropria custos fixos e variáveis aos produtos e que identifica todos os custos e despesas incorridos na atividade hospitalar, compreendendo o custeio de todos os insumos utilizados na produção do bem ou serviço, independente da origem dos custos ${ }^{(28)}$. 
Procura-se conhecer o quanto cada centro de custos absorve, em valor, dos demais centros de custos ou de fornecedores externos e a somatória corresponde ao produto do centro de custos em consideração ${ }^{(16)}$. Em outras palavras, os custos diretos e indiretos dos centros produtivos são somados ao rateio dos custos auxiliares e administrativos destes centros produtivos. A soma dos custos diretos e indiretos é o custo total.

Neste modelo de custeio "o hospital ou serviço de saúde pode ser entendido como um conjunto de centros de custos, interligados por um determinado processo de trabalho, que produzem bens e serviços de saúde" ${ }^{\prime(3,8)}$.

Todos os custos indiretos são apropriados aos produtos utilizando rateios que para seu cálculo seja baseado em algum critério a partir do todo, como por exemplo, valor pago pelo número de roupas lavadas por quilo de roupa $^{(11)}$.

Assim sendo, "cada centro de custos recebe insumos internos e/ou externos e produz bens ou serviços de caráter intermediário ou final" (38).

Este é um método utilizado por praticamente todas as organizações, incluindo as hospitalares, principalmente por atender às exigências fiscais, pois é o único método aceito pela legislação brasileira no cálculo do imposto de renda devido suas informações serem publicadas para demonstrações financeiras e para pagamento de impostos.

O custeio por absorção é uma das ferramentas utilizadas para o gerenciamento de custos; é o que possibilita melhor apuração e visualização dos custos por uma análise de cada uma das atividades realizadas na instituição e também permite relacionar estes custos aos produtos. Assim, para os produtos e processos são contabilizados os custos diretos, recebendo a parcela referente a eles, através de uma forma de rateio dos custos indiretos de onde estão sendo realizados ${ }^{(27)}$.

Porém, este método não possibilita a sua utilização completa para fins gerenciais, pois utiliza bases de rateio variáveis, dificultando o cálculo preciso do valor do produto. O rateio é caracterizado pelo cálculo da média de valores, portanto, na sua utilização, considera-se que todos os valores possuem as mesmas características, e sabe-se que esta não é a realidade. 
Entre outras desvantagens quando este método é utilizado para fins gerenciais, temos a dificuldade de atualização dos custos, pois eles são calculados ao término do processo contábil ${ }^{(39)}$.

Com esta dificuldade de exercer a contabilidade gerencial, emerge a necessidade de departamentalização da empresa, o que significa dividir a organização em áreas que poderão ser denominadas, de acordo com sua natureza e abrangência, em departamentos, serviços, setores e seções.

Nestas novas unidades operacionais, os centros de custos, são apropriados os custos diretos e indiretos dos produtos produzidos ou dos serviços prestados e podem ser classificados em produtivos, auxiliares e administrativos definidos no capítulo $3^{(40)}$.

Para a apuração dos custos dos centros de custos que compõem uma organização, as fases a serem seguidas são ${ }^{(27)}$.

$1^{\text {a }}$ fase: distribuição dos custos diretos (pessoal e materiais) aos centros de custos dos serviços produtivos, auxiliares e administrativos;

$2^{\text {a }}$ fase: identificação dos custos indiretos e seu rateio aos centros de custos dos serviços produtivos, auxiliares e administrativos (luz, telefone, gases, etc), utilizando a base de rateio mais adequada ao consumo do serviço. Exemplo: consumo de telefone pelo número de ramais de cada centro de custo;

$3^{\text {a }}$ fase: apuração do custo total (diretos e indiretos) de todos os centros de custos;

$4^{a}$ fase: rateio dos centros de custos auxiliares e administrativos aos centros produtivos, por meio de critérios que melhor representem o consumo destes custos pelos serviços produtivos;

$5^{\text {a }}$ fase: apuração do custo total de cada centro produtivo, podendo assim obter o custo de cada departamento pela soma dos custos de seus centros de custos e o custo total da organização pela soma dos custos dos departamentos.

Em suma, a apuração total de custo é conceituada como sendo "o processo de alocar todos os custos dos serviços de saúde a centros ou unidades de custos que produzem serviços finais" ${ }^{(41)}$. 
O cálculo do custo unitário dos serviços produzidos pode ser calculado mediante o valor total apurado pelos centros de custos no período de um mês.

O custeio por absorção pode ter como objeto de custos além dos serviços (centros de custos), os procedimentos médicos e de enfermagem.

Com isso, é um método que orienta o cálculo dos custos nos hospitais, porém ainda é de baixo conhecimento por parte de muitas enfermeiras e de elevada cobrança por parte das organizações de saúde.

\subsection{MÉTODO DE CUSTEIO PADRÃO}

O custo padrão é o custo determinado para o planejamento de um produto e deve ser calculado antes da produção de um bem ou serviço. Por este custo ser calculado de acordo com as condições habituais da empresa, levando em consideração as condições ambientais, empresariais e de mercado, ele pode ser identificado quando um produto entra em processo de fabricação. Este autor ainda ressalta que este custo não deve ser idealizado como custo estimado ${ }^{(29)}$.

O método de custeio padrão possibilita que o gestor conheça os custos, estabeleça um padrão de comportamento destes custos e assim, cria condições de controlá-los e avaliá-los na eficiência do processo de produção.

Entende-se por controle de custos a possibilidade de comparação entre algo que se tem (realidade), com algo que se espera e com isso, analisar as possíveis diferenças, identificar as causas e sempre que possível, tomar decisões com o objetivo de eliminar ou reduzir as diferenças ${ }^{(26)}$

Esta metodologia tem como finalidade o planejamento e controle com o objetivo de fixar uma base de comparação entre os custos reais e os planejados.

Embora muitos autores considerassem outro método de contabilização de custos como absorção e variável, este é considerado uma técnica auxiliar, pois sua utilização não significa a eliminação dos custos 
reais, em contrapartida, ele só é eficaz quando permite identificar as divergências existentes da extração da comparação de ambos ${ }^{(28)}$.

Para corresponder à finalidade de controle de custos, o método de custeio padrão ou standard é o que melhor atende ${ }^{(27)}$.

\subsection{MÉTODO DE CUSTEIO VARIÁVEL OU DIRETO}

O custeio variável ou direto é um método que vem sendo utilizado pelas organizações, pois possibilita gerar informações mais rápidas para o processo de tomada de decisões como, por exemplo, a fixação de preços e o cálculo da lucratividade dos produtos ${ }^{(27)}$.

A autora ainda coloca que para essa finalidade os custos fixos não têm muita utilidade, uma vez que tendem a ser mais um encargo para que a empresa possa operar, ou seja, ter instalada a sua capacidade de produção, do que para produzir uma unidade a mais de um produto ${ }^{(27)}$.

Assim, no custeio variável só são alocados aos produtos os custos variáveis, ficando os fixos separados e considerados como despesas do período(26). Consiste então, em apropriar à produção, todos os custos variáveis, diretos e indiretos.

Os produtos são distribuídos por base de rateio com elevado grau de arbitrariedade e avaliando também a possibilidade de variação de um custo de um produto em função não de seu volume, mas da quantidade de outros bens ou serviços produzidos. Segundo Martins ${ }^{(28)}$, no custeio variável os custos fixos ficam separados e são considerados como despesas do período, sendo somente os custos variáveis alocados aos produtos, daí a nomenclatura de método de custeio variável.

Diferente do custeio por absorção, este tipo de custeio, é destinado a suprir os gestores com as informações necessárias para uma tomada de decisão oferecendo possibilidades claras de análises do comportamento dos custos $^{(13)}$.

O custeio variável tem como objetivo principal determinar a margem de contribuição de cada produto que é o excedente sobre os custos 
variáveis e o cálculo desta margem gera o resultado do quanto cada produto contribui para a cobertura dos custos fixos e o lucro ${ }^{(42)}$.

Este custeio permite a análise da lucratividade dos produtos ou serviços pela obtenção do ponto de equilíbrio e da margem de contribuição ${ }^{(27)}$.

Ponto de equilíbrio é definido como sendo a avaliação do nível das atividades em que não há lucro nem prejuízo. Neste nível, afirma-se que ocorreu a cobertura total dos custos fixos. Conclui-se que produzindo atividade em volume abaixo deste ponto, o setor está em prejuízo, e acima, onde aparecem os custos variáveis, o setor está obtendo lucros ${ }^{(28)}$.

Autores caracterizam margem de contribuição como sendo a diferença entre o preço de venda e o custo variável de cada produto, parcela esta em que cada setor de produção contribui para a absorção dos custos fixos e geração de lucros ${ }^{(26,40)}$.

A diferença principal entre este método e o método de absorção é que o método de absorção apropria aos produtos todos os custos de produção, fixos e variáveis, diretos e indiretos, e o método variável apropria todos os custos variáveis de produção, independentes da classificação entre diretos e indiretos e ainda tratam os custos fixos como despesas do período ${ }^{(39)}$.

\subsection{MÉTODO DE CUSTEIO POR ATIVIDADE: MÉTODO ABC (ACTIVITY-BASED COSTING)}

As empresas em geral vêm desde a década de 1980 procurando alternativas para adequarem-se ao mundo cada vez mais competitivo e com isso algumas novas tecnologias de produção e de gestão foram desenvolvidas.

Até então, as empresas calculavam seus custos de maneira simples, apropriando somente o custo direto da mão-de-obra somada ao custo da matéria-prima. Estes eram os custos identificados na época como sendo os custos de um produto ou serviço e por serem representativos, permitiam aos gestores, tomadas de decisões seguras ${ }^{(29)}$. 
De tal maneira, os custos indiretos não afetavam os custos determinados uma vez que eram menos representativos.

Com o aprimoramento das tecnologias e diversificação das técnicas de produção, os custos indiretos passaram a contribuir significativamente com os custos e conseqüentemente houve uma diminuição do custo da mão-de-obra. Com isso, houve uma inversão no valor dos custos e aqueles custos diretos que eram muito representativos passaram a contribuir com uma parcela menor do cálculo do custo do produto, e os custos indiretos contribuíram com uma parcela mais significativa. Deste modo, o cálculo de custos utilizado na época já não era mais suficiente para o mercado de produção e buscando atender à demanda dos gestores, pesquisadores e estudiosos desenvolveram novas técnicas para a gestão de custos ${ }^{(29)}$.

Para a melhoria de processos e eliminação de desperdícios que aumentam os custos da produção e reduzam a lucratividade ou a competitividade das empresas o melhor sistema é o Custeio baseado em atividades ${ }^{(27)}$. Diante disso, alguns autores apontam o custeio baseado em atividades (Activity-Based Costing-ABC) como uma ferramenta eficaz para análise estratégica de custos e das atividades que geram os custos ${ }^{(43,44)}$.

Historicamente, o método de custeio $A B C$ teve origens nos Estados Unidos, em meados dos anos 90, com a concorrência forte do Japão, muitas empresas americanas adotaram novas filosofias de gestão e também desenvolveram novas tecnologias de produção ${ }^{(10)}$.

$O$ método $A B C$ também conhecido como Custeio Baseado em Atividade em inglês Activity-Based Costing ( $A B C)$, não é uma alternativa nova de contabilidade de custos nas instituições de saúde. Porém, é uma metodologia que tem como objetivo a redução das distorções conseqüentes dos rateios de custos indiretos nas instituições e eliminação de desperdícios que aumentam os custos de produção e reduzem a lucratividade ou a competitividade das organizações ${ }^{(9,11)}$.

O método de custeio $A B C$ permite a apuração do custo dos produtos, serviços ou outros objetos de custeio tendo como base a seguinte filosofia: os recursos de uma empresa são consumidos pelas atividades executadas, e os produtos, serviços ou outros objetos de custeio resultam das atividades 
que esses recursos requerem. Desta maneira, ocorre a apropriação dos custos indiretos às atividades e em seguida aos produtos, serviços ou outros objetos de custeio que determinam tais atividades ${ }^{(29)}$.

Outros autores corroboram com este conceito e acrescentam que em cada produto deve ser agregada uma parcela do componente de custo com base na proporção de cada atividade que ele produz ${ }^{(45)}$.

A metodologia $A B C$ pode ser utilizada como ferramenta eficaz para análise estratégica dos custos e também para as atividades que geram custos. Pode custear tanto serviços, quanto pacientes e procedimentos específicos na instituição.

Um dos benefícios obtidos com a utilização desta modalidade de custeio é o fato deste permitir uma melhoria nas decisões gerenciais ${ }^{(46)}$.

A escolha pelo método de custeio $A B C$ ocorre em situações onde há necessidade de melhor aprofundamento no conhecimento dos custos indiretos uma vez que eles são mensurados e rateados para todos os setores usuários. Já os custos diretos, aqueles conhecidos pelos seus valores reais, são mensurados de uma maneira mais clara e simples, evitando distorções, pois não há necessidade de realizar o rateio.

Possibilita, assim, a descrição dos processos e de suas atividades, permitindo a identificação de como os custos distribuem-se na produção e apontando quais são as ferramentas gerenciais que podem ser utilizadas na eliminação destas atividades que não agregam valor ${ }^{(27)}$.

Há duas designações sobre o método $A B C$ : a designação de custos e de processos $^{(9)}$.

A primeira designação, a de custos, pode ser dividida em duas etapas. Primeiramente os recursos são alocados às atividades utilizando direcionadores de recursos e em seguida passam a ser alocados aos objetos específicos de custo.

Entende-se por atividade "um conglomerado de ações executadas dentro de uma organização visando determinada finalidade" (9).

Direcionadores de recursos são "aqueles que identificam como as atividades consomem recursos" (29). 
Por objetos de custo entende-se "qualquer paciente, produto, serviço, contrato, projeto, ou qualquer outra unidade de trabalho para a qual a medida separada de custo seja desejada" ${ }^{(9)}$.

A designação de custos tem por objetivo conhecer a maneira mais apurada possível do custo do objeto conhecendo também os componentes de formação deste custo.

A segunda designação é a de processos, na qual para cada atividade são conhecidos os veículos de custos, caracterizados por qualquer fator que causa alteração no custo de uma atividade, utilizando direcionadores de atividades $^{(9)}$.

Entende-se por direcionadores de atividades aqueles que "identificam como os objetos de custeio consomem as atividades, permitindo custeá$\operatorname{los}^{(29)}$.

O método $A B C$, dependendo de qual for o objeto de custo, não apresenta tanta diferença do método tradicional de custeio, ele somente atribui de maneira diferente os custos aos produtos. O grande desafio está em escolher o diferenciador de custos que é definido como "fator que determina o custo de uma atividade" e, portanto entende-se que o direcionador é a real causa dos custos, pois todas as atividades exigem recursos para serem realizadas. $O$ autor ainda coloca que o diferenciador de custos é o que determina a maneira como os produtos utilizam as atividades $^{(11)}$.

O importante na realização do método $A B C$ é o conhecimento prévio e definição das atividades realizadas em cada um dos setores e conseqüentemente o conhecimento dos direcionadores de custos.

As informações geradas pelos métodos de custeio auxiliam os gestores de toda a organização, a avaliarem profundamente os resultados de suas unidades, incluindo os recursos que ficam sob sua responsabilidade para a execução das metas estabelecidas.

Nas organizações de saúde, as enfermeiras têm se envolvido cada vez mais na apuração dos custos e no seu controle, atuando em conjunto com os gestores das áreas administrativa e financeira. Por serem 
responsáveis pelas unidades hospitalares, as enfermeiras prestam contas do desempenho de suas unidades mediante o uso de relatórios contábeis. 
5 AS QUESTÕES DA PESQUISA 


\section{AS QUESTÕES DA PESQUISA}

As questões desta pesquisa são:

- As enfermeiras possuem conhecimentos para o gerenciamento de custos?

- As enfermeiras se sentem preparadas para assumir tal função?

- Quais são as ferramentas utilizadas pelas enfermeiras no gerenciamento de custos em suas unidades de trabalho?

- Quais são as atividades realizadas pelas enfermeiras, em seu ambiente de trabalho, relacionadas à gestão de custos? 
6 OBJETIVOS 


\section{OBJETIVOS}

\subsection{OBJETIVO GERAL}

- Analisar a participação das enfermeiras no gerenciamento de custos, em organizações hospitalares, no município de São Paulo.

\subsection{OBJETIVOS ESPECÍFICOS}

- Caracterização da população e do local de estudo;

- Levantar as atividades desenvolvidas pelas enfermeiras relacionadas à gestão de custos;

- Apresentar o conhecimento das enfermeiras sobre custos e métodos de custeio;

- Verificar as dificuldades e as facilidades das enfermeiras relacionadas às atividades de gerenciamento de custos;

- Identificar as vantagens que essa participação tem trazido para o gerenciamento do serviço de enfermagem. 


\section{MÉTODO}

\subsection{TIPO DO ESTUDO}

O estudo foi de cunho exploratório-descritivo comparativo e correlacional, com abordagem quantitativa, no qual se procurou identificar a participação das enfermeiras no gerenciamento de custos.

Como a finalidade deste estudo é de identificar a participação das enfermeiras no gerenciamento de custos em organizações hospitalares, a escolha do método exploratório descritivo foi justificada, pois este permite "coletar descrições detalhadas das variáveis existentes e usa os dados para justificar e avaliar condições e práticas correntes" permitindo então propor melhorias nas práticas de atenção à saúde ${ }^{(47)}$.

Foi desenvolvido um estudo correlacional, pois este permite examinar a relação entre duas ou mais variáveis. Possibilita avaliar se as variáveis variam conjuntamente, ou seja, "à medida que uma variável muda, uma mudança relacionada ocorre na outra variável" ${ }^{(47)}$.

\subsection{LOCAL DO ESTUDO}

O estudo foi realizado em duas organizações hospitalares do município de São Paulo, sendo uma privada e a outra pública com contrato de parceria público-privada (Organização Social), nas quais se obteve autorização para o desenvolvimento da pesquisa. Estas organizações foram incluídas no estudo, porque apresentam modelo de gestão por resultados e por qualidade; possuem sistemas de gestão de custos implantados e referem que as enfermeiras participam desta gestão.

Houve a intenção de realizar este estudo também em outras instituições privadas e públicas, cujas enfermeiras participam na gestão de custos, porém não se obteve autorização.

A instituição de saúde privada onde foi desenvolvido este estudo é um hospital filantrópico, de grande porte, que atende todas as especialidades 
clínico-cirúrgicas (clínica médica, ginecologia e obstetrícia, pediatria, clínica cirúrgica, unidade de urgência e emergência, terapia intensiva adulto, pediátrica e neonatal, cardiologia, ortopedia, oncologia, hematologia e reabilitação. O nível de referência é quaternário.

O hospital destaca-se pelo seu desempenho em procedimentos de alta complexidade, atendendo a todas as demandas da cadeia de valor de prevenção, diagnóstico, tratamento e reabilitação da saúde.

Hoje, esta instituição ocupa posição de vanguarda entre as instituições hospitalares da América Latina, é certificada pela Joint Commission International e ainda dispõe de certificações International Organization for Standardization (ISO) em diversas áreas.

O quadro de funcionários fornecido pela instituição é de mais de nove mil e destes, aproximadamente $40 \%$ tem ensino superior, com tempo médio dos funcionários na instituição de cinco anos. Conta com o corpo clínico de 6.000 médicos cadastrados.

Está localizada na zona sul da cidade de São Paulo e possui uma área de $70 \mathrm{mil} \mathrm{m} \mathrm{m}^{2}$ construídos, com 200 consultórios de várias especialidades, 20 salas cirúrgicas, 41 apartamentos para internação-dia.

Realiza anualmente uma média de 180 mil atendimentos de ProntoSocorro, 500 mil exames diagnósticos, 15 mil internações e 3800 partos.

A outra organização de saúde selecionada para campo desta pesquisa é uma organização social, municipal, com atendimento exclusivo à rede do SUS, gerenciada pela instituição privada descrita acima.

Organização Social é a qualificação dada às entidades privadas sem fins lucrativos entre elas associações, fundações ou sociedades civis, que exercem atividades de interesse público. Esse título permite que a organização receba recursos orçamentários e administre serviços, instalações e equipamentos do Poder Público, após ser firmado um Contrato de Gestão com o Governo Federal ou municipal ${ }^{(49)}$.

O modelo de gestão utilizado nas organizações sociais é por resultados e estas são gerenciadas com metas e orçamentos negociados com a Secretaria Municipal de Saúde, conforme a Lei $n^{\circ}$ 9.637, de 15 de Maio de $1998^{(49)}$. 
Atende a comunidade da região dos bairros do Jardim Ângela e Jardim São Luiz, que juntos somam cerca de 600 mil habitantes. É instituição de referência para 43 unidades de saúde (31 Unidades Básicas de Saúde, nove unidades de Assistência Médica Ambulatorial (AMA), dois AMAs de especialidades e um ambulatório de especialidades).

A Instituição tem como foco 0 atendimento de urgências, emergências e parto e está localizada na zona sul da cidade de São Paulo, possui 27 mil $\mathrm{m}^{2}$ de área construída distribuídos em cinco pavimentos. Conta com 1.400 colaboradores diretos, sendo cerca de $40 \%$ moradores da região e possui aproximadamente 230 leitos operacionais sendo 39 de UTI e os demais distribuídos entre pediatria, clínica médico-cirúrgica, obstetrícia, psiquiatria, neonatologia e pronto-socorro.

Realiza mensalmente uma média de 15 mil atendimentos de urgência e emergência, nove mil exames de diagnóstico por imagem, 30 mil exames laboratoriais e 350 partos.

\subsection{AMOSTRA DO ESTUDO}

A amostra do estudo foi intencional, sendo constituída por 187 enfermeiras dos três turnos de atividade, matutino, vespertino e noturno, que atuam na assistência das clínicas selecionadas nas instituições. Esta amostra representou $23,64 \%$ da população de enfermeiras atuantes nas clínicas médicas-cirúrgicas das instituições estudadas.

O critério de inclusão da amostra de enfermeiras foi atuar na instituição há pelo menos seis meses.

A indicação da divisão de clínica médica-cirúrgica, que possui maior número de enfermeiras em seu quadro de profissionais, para coleta de dados da amostra do estudo, foi realizada pela enfermeira que ocupa o cargo da enfermagem de maior nível hierárquico na instituição.

Não houve enfermeira que se recusou a participar do estudo, porém algumas profissionais estavam gozando período de férias e não fizeram parte do estudo. 
$\mathrm{Na}$ Instituição A, hospital da rede privada, a amostra do estudo foi composta por 172 (22,5\%) enfermeiras atuantes nas clínicas médica e cirúrgica, que engloba oncologia e transplante de medula óssea. O quadro de enfermeiras da divisão de Clínica Médica-Cirúrgica nesta instituição é de 765 e uma coordenadora de enfermagem e contam com 377 leitos.

$\mathrm{Na}$ Instituição B, a organização de saúde, a amostra do estudo foi composta por $15(57,7 \%)$ enfermeiras que atuam nas clínicas médica e cirúrgica. Os setores contam com 78 leitos sob a supervisão de 26 enfermeiras.

O tamanho da amostra foi discutido com um estatístico antes da coleta de dados e foi de aproximadamente $20 \%$ da população. Como a Instituição B possui um quadro de enfermeiras na clínica médico-cirúrgica de 26, inferior ao quadro da Instituição A (765 enfermeiras) se fosse mantido o percentual de $20 \%$ teria somente cinco enfermeiras como amostra. A partir disso, foi decidido aumentar o tamanho da amostra de enfermeiras da Instituição B para 15 com a finalidade de atingir um número mais representativo para discussão nos resultados.

\subsection{INSTRUMENTO DE COLETA DE DADOS}

Para coleta de dados foram utilizados dois instrumentos.

$O$ instrumento $A$ (APÊNDICE A) foi elaborado com a finalidade de obter dados referentes à caracterização das instituições de saúde. Os dados coletados neste instrumento apresentaram o tipo de instituição, número de leitos, especialidades, nível de referência, método de custeio utilizado e conhecimento e participação na elaboração do orçamento.

Este instrumento foi aplicado às duas enfermeiras que ocupavam cargo de maior nível hierárquico, no momento do estudo, nas instituições selecionadas.

O instrumento B (APÊNDICE B) foi elaborado para caracterizar a amostra do estudo, identificar os conhecimentos das enfermeiras e a participação delas no gerenciamento de custos. Este instrumento foi aplicado às 187 enfermeiras. 
A primeira seção deste instrumento apresentava questões relacionadas à caracterização das enfermeiras quanto ao gênero, idade, tempo de formação, tempo de atuação na instituição, cargo, tempo de atuação no cargo, aprimoramento específico em custos e maior titulação.

A segunda seção destinou-se à avaliação do conteúdo das práticas gerenciais em custos com questões referentes ao conhecimento sobre custos hospitalares e orçamentos.

A terceira seção destinou-se ao conhecimento das enfermeiras sobre principais conceitos de custos hospitalares, seção esta com questões conceituais objetivas.

A última seção destinou-se às questões referentes às condições institucionais para a realização do gerenciamento de custos das enfermeiras. Nesta seção, havia um espaço com questões abertas para a enfermeira relatar as dificuldades e as vantagens relacionadas a essas atividades de gerenciamento de custos que ela desenvolve no cotidiano de sua prática profissional.

\subsection{PROCEDIMENTO PARA A VALIDAÇÃO DO CONTEÚDO DO QUESTIONÁRIO}

Antes de iniciar a coleta de dados propriamente dita, foi realizado um estudo nos meses de abril e maio de 2011 para validação do instrumento $B$ (APÊNDICE B) de pesquisa.

Para selecionar as principais práticas gerenciais em custo e transformá-las em questões, tomou-se como base:

a) A revisão da literatura de contabilidade gerencial e de custos e sua aplicação na análise de custos em saúde e enfermagem;

b) A elaboração dos principais conteúdos relacionados à literatura;

c) Elaboração do instrumento B (APÊNDICE B) para levantamento das práticas junto às enfermeiras, gerentes de serviços hospitalares, para levantamento do conhecimento e utilização dessas práticas;

Nesta etapa, procurou-se reconhecer o quanto a medida incorpora o domínio dos fenômenos que se pretende medir, ou seja, a validação teórica. 
Para tanto, foi empregado o método de Validade de Conteúdo ou Avaliação Opinativa, por meio de opiniões de especialistas, que neste estudo foram denominados de juízes.

A validação de conteúdo é um processo que compreende duas fases: o desenvolvimento do instrumento e o julgamento pelos especialistas, visando obter o índice de consenso ${ }^{(49)}$.

Para a obtenção dos dados elaborou-se um questionário intitulado "Instrumento para validação opinativa do conteúdo para mensurar o conhecimento das enfermeiras no gerenciamento de custos em organizações hospitalares" (APÊNDICE C).

Este instrumento foi composto por quatro seções, sendo elas:

Parte I - Caracterização profissional: gênero, idade (anos), tempo de formação (anos), instituição de trabalho (pública ou privada), cargo/função exercida, graduação e titulação.

Parte II - Avaliação do conteúdo das práticas gerenciais em custos;

Parte III - Conhecimento dos gestores sobre principais conceitos de custos hospitalares;

Parte IV - Condições institucionais para a realização do gerenciamento de custos.

Essa avaliação visou levantar as opiniões dos juízes quanto à adequação e suficiência do seu conteúdo e a sua aplicabilidade prática. Os resultados foram obtidos por meio de assertivas, possibilitando respostas afirmativas ou negativas. Foi previsto um espaço para os comentários e as sugestões dos especialistas;

Em relação à constituição do grupo de juízes, foi composto por profissionais com amplo conhecimento e experiência em gestão de custos, atuantes no ensino, na pesquisa e no gerenciamento de serviços.

Assim, considerou-se para essa composição enfermeiras de instituições públicas e privadas que ocupam cargo de chefia; médicos ou enfermeiras que ocupam cargos administrativos, docentes de enfermagem e de contabilidade que ministram gerenciamento de custos em saúde e contadores de hospitais. 
A revisão de literatura mostrou não haver consenso quanto ao número ideal de juízes para avaliação de instrumentos. Isto depende da acessibilidade que o pesquisador dispõe para contatar os profissionais envolvidos na temática estudada ${ }^{(49)}$.

Recomenda-se a participação de três a dez especialistas na validação do conteúdo, observando-se a experiência acumulada e para o fato do julgamento ser realizado individualmente ${ }^{(50)}$.

Para este trabalho foram selecionados e convidados 15 especialistas, do município de São Paulo. O contato foi feito por via eletrônica, com o intuito de expor os objetivos e o método de estudo e acordar o prazo para entrega do conteúdo julgado. Todos os contactados aceitaram participar.

No que diz respeito ao procedimento de coleta de dados, foi encaminhado o questionário opinativo formulado para os juízes (APÊNDICE C) e o questionário com as questões a serem aplicados às enfermeiras posteriormente (APÊNDICE B), em março e abril de 2011.

Ressalta-se que dois participantes não devolveram o material e, dessa forma, a validação do conteúdo foi realizada por 13 especialistas.

Em relação à validação de conteúdo ela se dá mediante a obtenção de opiniões convergentes dos participantes, conhecida como consenso grupal. Para isso, é necessário estabelecer um índice de validação de conteúdo, também conhecido como índice de consenso ou de favorabilidade $^{(50)}$.

Para este estudo empregamos o valor mínimo de $\geq 75 \%$ para a concordância entre os juízes, conforme estudos realizados por Silva ${ }^{(51)}$ e Fernandes $^{(52)}$. 


\subsection{APRESENTAÇÃO E ANÁLISE DOS RESULTADOS DA VALIDAÇÃO}

Os resultados foram analisados estatisticamente com abordagem descritiva e foram apresentados em tabelas e figuras, com número absoluto e relativo.

\subsubsection{Caracterização dos juízes}

O questionário foi analisado por 13 especialistas. A idade variou entre 31 e 53 anos, sendo a média de 44,08 anos (DP $\pm 5,96$ ) e a mediana de 44 anos. No gráfico abaixo apresentamos a distribuição das freqüências nas faixas etárias.

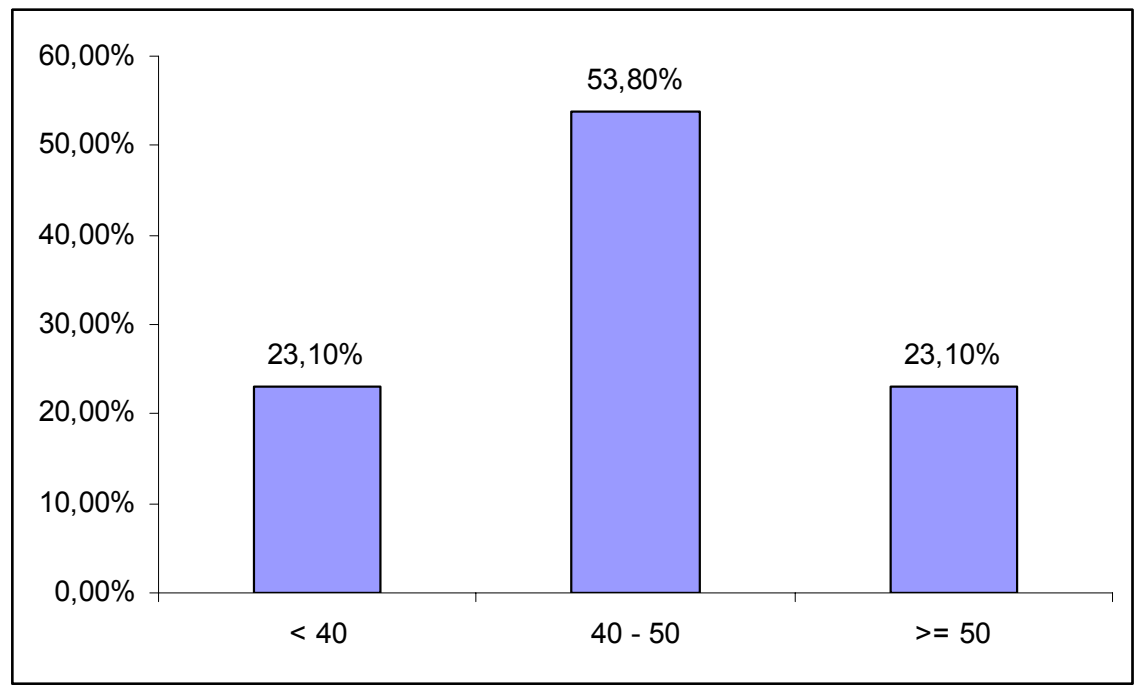

Figura 4 - Distribuição de freqüências dos 13 juízes em relação à idade, São Paulo- 2011

Para a descrição do perfil profissional destes juízes temos, em relação à graduação, 12 (92,3\%) especialistas enfermeiras e um (7,7\%) contador, demonstrado na Figura 5. 


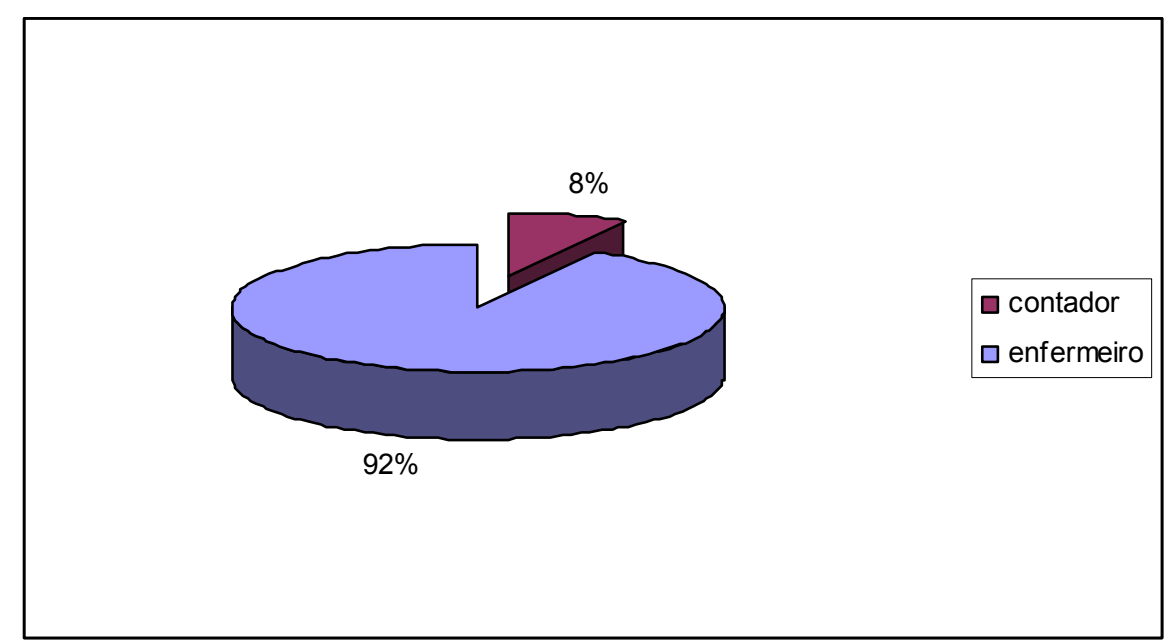

Figura 5 - Distribuição de freqüências dos 13 juízes em relação à graduação, São Paulo 2011

O tempo de formado variou entre dez e 29 anos, sendo a média de 20,77 anos (DP $\pm 6,43$ ) e mediana de 22 anos (Figura 6).

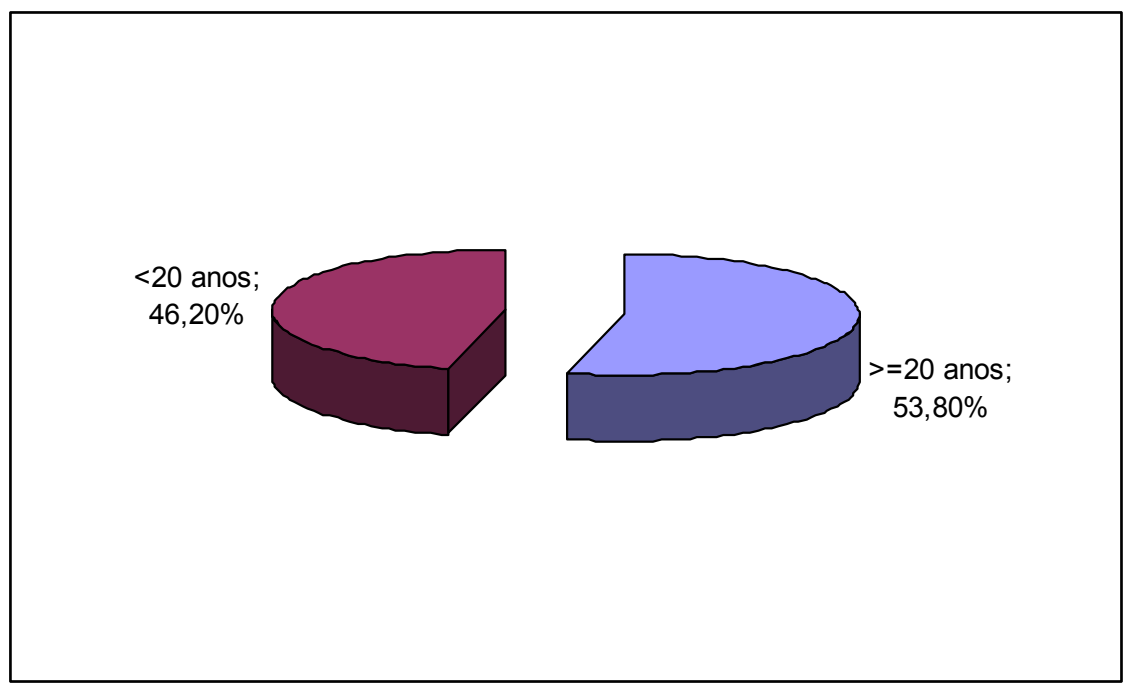

Figura 6 - Distribuição de freqüências dos 13 juízes em relação ao tempo de formado, São Paulo - 2011

Em relação ao tempo de função, a média correspondeu há 6,23 anos $(\mathrm{DP} \pm 4,11)$ e mediana de cinco anos, variando entre dois e 13 anos (Figura 7). 


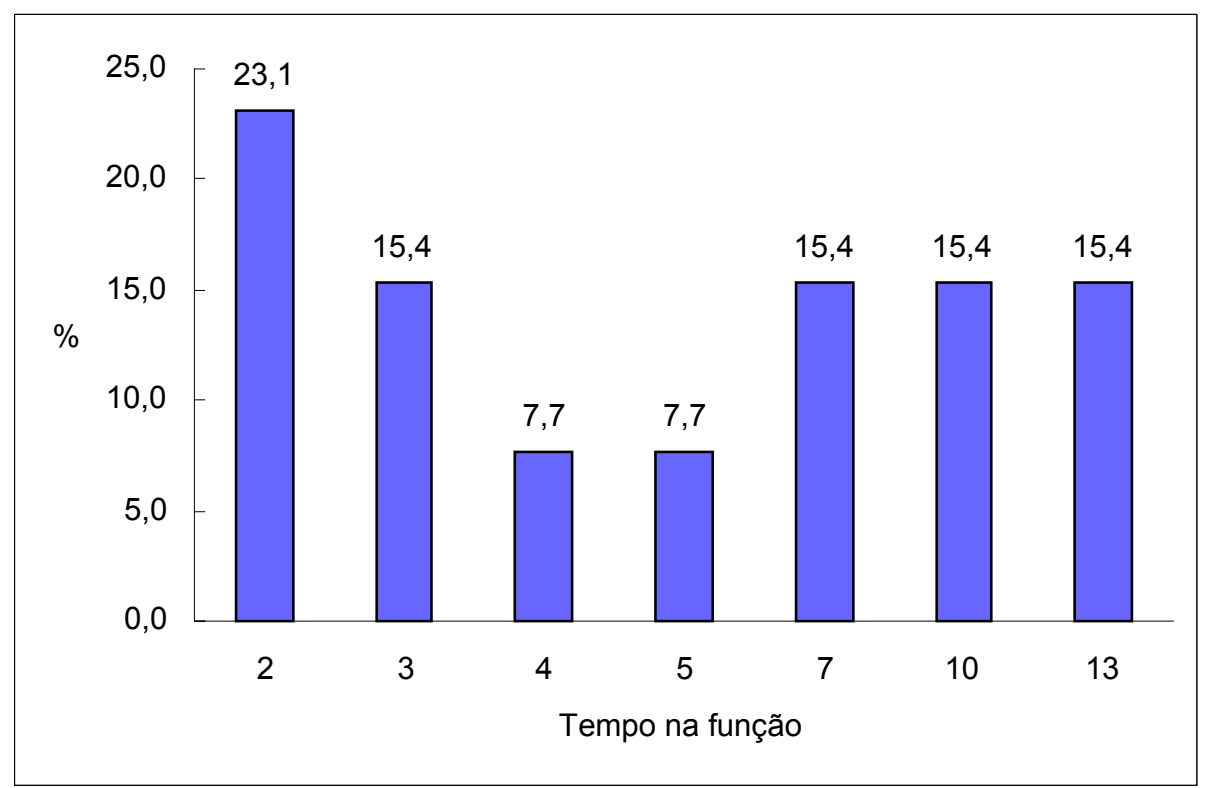

Figura 7 - Distribuição de freqüências dos 13 juízes em relação ao tempo na função, São Paulo - 2011

No que tange à natureza jurídica da instituição onde os especialistas atuavam, observou-se que seis (46,2\%) pertenciam à instituição privada, seis $(46,2 \%)$ em pública e um $(7,7 \%)$ em um hospital público gerenciado por uma organização social (OS), conforme demonstrado na figura a seguir.

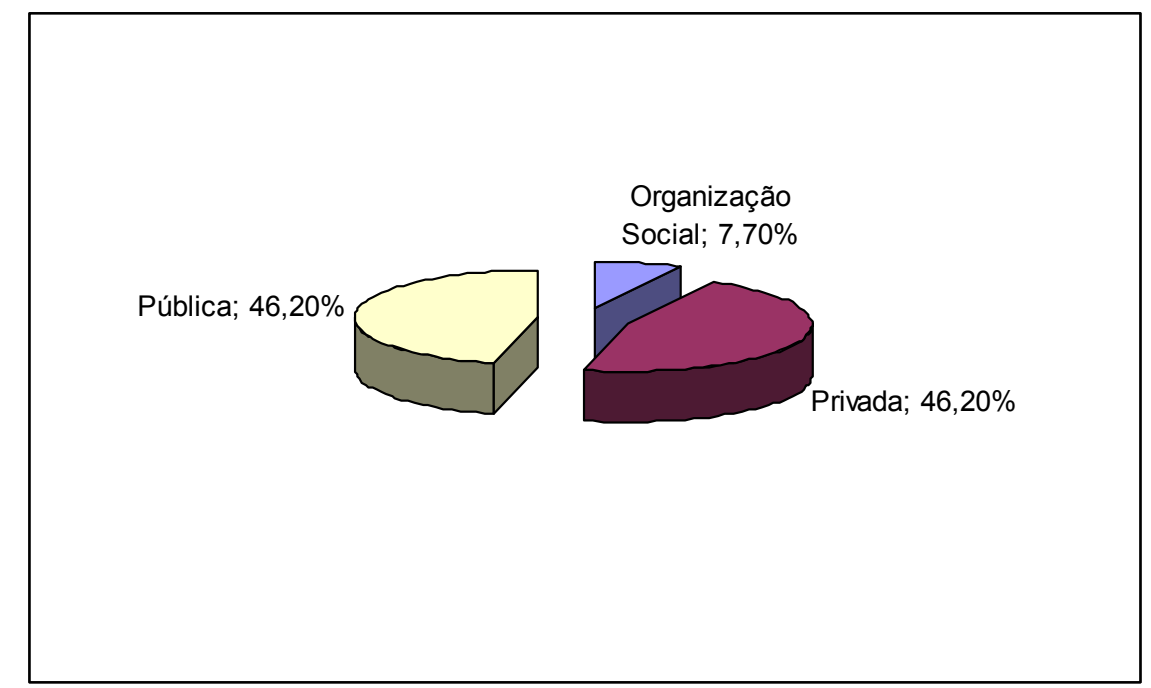

Figura 8 - Distribuição de freqüências dos 13 juízes em relação à natureza da instituição, São Paulo - 2011

Em relação ao cargo/função dos juízes cinco (38,5\%) eram diretores de serviço de enfermagem, uma enfermeira auditora contábil $(7,7 \%)$, quatro $(30,8 \%)$ docentes de administração em enfermagem e três $(23,1 \%)$ gerentes administrativos, sendo duas enfermeiras e um contador (Figura 9). 


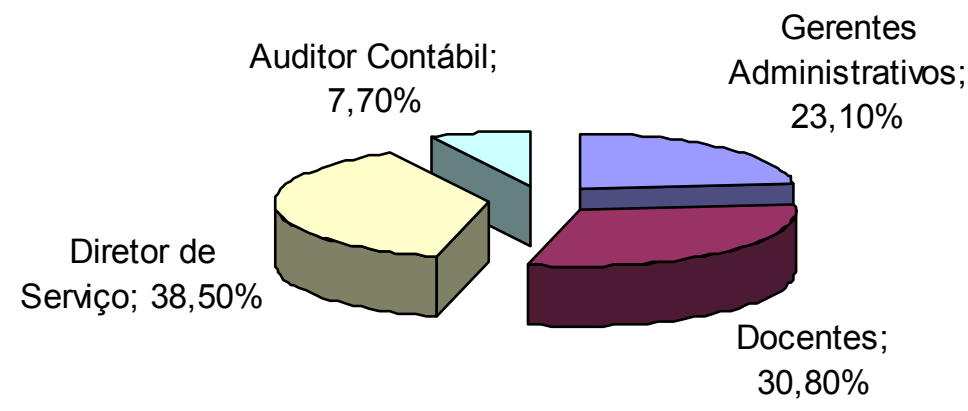

Figura 9 - Distribuição de freqüências dos 13 juízes em relação ao cargo/função, São Paulo $-2011$

Em relação à titulação dos especialistas, dois (15,4\%) eram doutores, seis $(46,2 \%)$ mestres e cinco $(38,5 \%)$ com especialização. Vale ressaltar que houve predomínio de especialistas com pós-graduação stricto sensu $(61,6 \%)$.

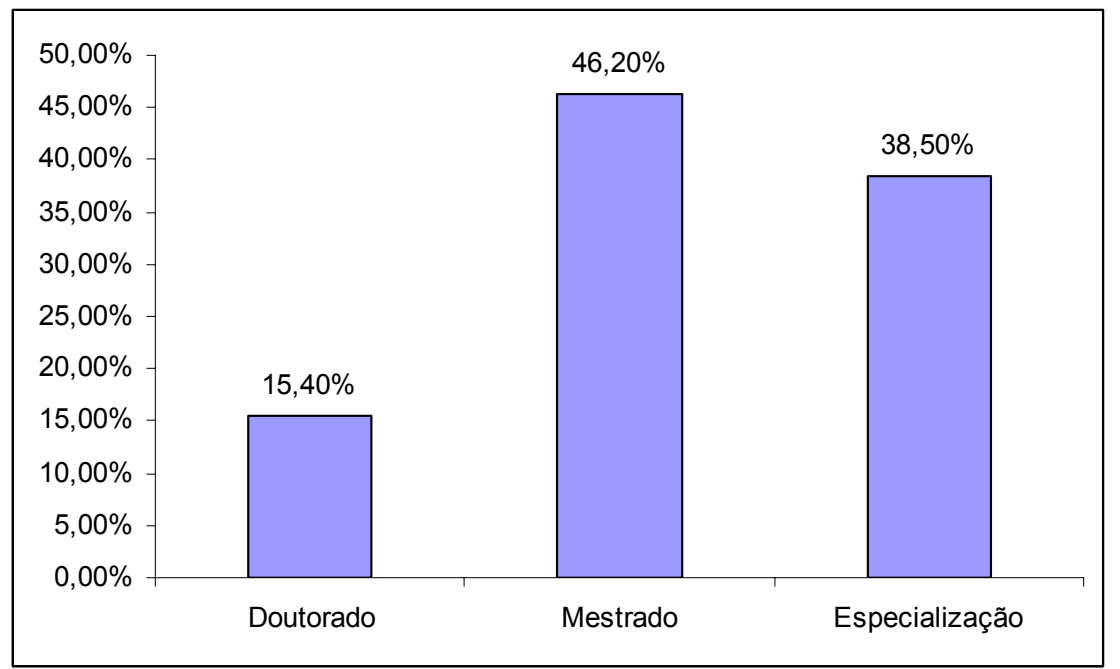

Figura 10 - Distribuição de freqüências dos 13 juízes em relação à titulação, São Paulo 2011 


\subsubsection{Validação do Conteúdo}

A seguir, foram descritos os achados referentes à validação pelos especialistas dos indicadores de avaliação dos conteúdos do questionário. Conforme descrito no método, os juízes avaliaram as questões sobre o conteúdo das práticas gerenciais em custos, o conhecimento das enfermeiras sobre os principais conceitos de custos aplicados no ambiente hospitalar e as condições institucionais para a realização do gerenciamento de custos.

Cabe lembrar que para este estudo foi empregado o valor mínimo de $\geq 75 \%$ para a concordância entre os juízes, conforme descrito no método.

Conforme descrito na Tabela 1, 100\% dos juízes concordaram em manter o conteúdo do questionário. Assim, os conteúdos obtiveram consenso favorável com $\geq 75 \%$, no que se refere às práticas gerenciais, conhecimento sobre essas práticas e condições institucionais. 
Tabela 1 - Consenso de julgamento pelos juízes dos itens dos conteúdos, São Paulo - 2011

\begin{tabular}{|c|c|c|c|c|c|c|}
\hline \multirow[t]{2}{*}{ Itens do Conteúdo } & \multicolumn{2}{|c|}{$\begin{array}{l}\text { Parte II } \\
\text { Práticas gerenciais }\end{array}$} & \multicolumn{2}{|c|}{$\begin{array}{l}\text { Parte III } \\
\text { Conhecimento }\end{array}$} & \multicolumn{2}{|c|}{$\begin{array}{c}\text { Parte IV } \\
\text { Condições } \\
\text { institucionais }\end{array}$} \\
\hline & $\mathbf{N}$ & $\%$ & $\mathbf{N}$ & $\%$ & $\mathbf{N}$ & $\%$ \\
\hline \multicolumn{7}{|l|}{ Questão 1} \\
\hline Manter & 13 & 100 & 13 & 100 & 13 & 100 \\
\hline Excluir & 0 & 0 & 0 & 0 & 0 & 0 \\
\hline Alterar & 0 & 0 & 0 & 0 & 0 & 0 \\
\hline Total & 13 & 100 & 13 & 100 & 13 & 100 \\
\hline \multicolumn{7}{|l|}{ Questão 2} \\
\hline Manter & 13 & 100 & 13 & 100 & 13 & 100 \\
\hline Excluir & 0 & 0 & 0 & 0 & 0 & 0 \\
\hline Alterar & 0 & 0 & 0 & 0 & 0 & 0 \\
\hline Total & 13 & 100 & 13 & 100 & 13 & 100 \\
\hline \multicolumn{7}{|l|}{ Questão 3} \\
\hline Manter & 13 & 100 & 13 & 100 & 13 & 100 \\
\hline Excluir & 0 & 0 & 0 & 0 & 0 & 0 \\
\hline Alterar & 0 & 0 & 0 & 0 & 0 & 0 \\
\hline Total & 13 & 100 & 13 & 100 & 13 & 100 \\
\hline \multicolumn{7}{|l|}{ Questão 4} \\
\hline Manter & 13 & 100 & 13 & 100 & 13 & 100 \\
\hline Excluir & 0 & 0 & 0 & 0 & 0 & 0 \\
\hline Alterar & 0 & 0 & 0 & 0 & 0 & 0 \\
\hline Total & 13 & 100 & 13 & 100 & 13 & 100 \\
\hline \multicolumn{7}{|l|}{ Questão 5} \\
\hline Manter & 13 & 100 & 13 & 100 & & \\
\hline Excluir & 0 & 0 & 0 & 0 & & \\
\hline Alterar & 0 & 0 & 0 & 0 & & \\
\hline Total & 13 & 100 & 13 & 100 & & \\
\hline \multicolumn{7}{|l|}{ Questão 6} \\
\hline Manter & 13 & 100 & 13 & 100 & & \\
\hline Excluir & 0 & 0 & 0 & 0 & & \\
\hline Alterar & 0 & 0 & 0 & 0 & & \\
\hline Total & 13 & 100 & 13 & 100 & & \\
\hline \multicolumn{7}{|l|}{ Questão 7} \\
\hline Manter & 13 & 100 & 13 & 100 & & \\
\hline Excluir & 0 & 0 & 0 & 0 & & \\
\hline Alterar & 0 & 0 & 0 & 0 & & \\
\hline Total & 13 & 100 & 13 & 100 & & \\
\hline \multicolumn{7}{|l|}{ Questão 8} \\
\hline Manter & 13 & 100 & 13 & 100 & & \\
\hline Excluir & 0 & 0 & 0 & 0 & & \\
\hline Alterar & 0 & 0 & 0 & 0 & & \\
\hline Total & 13 & 100 & 13 & 100 & & \\
\hline \multicolumn{7}{|l|}{ Questão 9} \\
\hline Manter & 13 & 100 & 13 & 100 & & \\
\hline Excluir & 0 & 0 & 0 & 0 & & \\
\hline Alterar & 0 & 0 & 0 & 0 & & \\
\hline Total & 13 & 100 & 13 & 100 & & \\
\hline \multicolumn{7}{|l|}{ Questão 10} \\
\hline Manter & 13 & 100 & 13 & 100 & & \\
\hline Excluir & 0 & 0 & 0 & 0 & & \\
\hline Alterar & 0 & 0 & 0 & 0 & & \\
\hline Total & 13 & 100 & 13 & 100 & & \\
\hline
\end{tabular}


Tabela 1 - Consenso de julgamento pelos juízes dos itens dos conteúdos, São Paulo - 2011 Continuação

\begin{tabular}{|c|c|c|c|c|}
\hline Questão 11 & & & & \\
\hline Manter & 13 & 100 & 13 & 100 \\
\hline Excluir & 0 & 0 & 0 & 0 \\
\hline Alterar & 0 & 0 & & 0 \\
\hline Total & 13 & 13 & 13 & 100 \\
\hline Questão 12 & & & & \\
\hline Manter & & & 13 & 100 \\
\hline Excluir & & & 0 & 0 \\
\hline Alterar & & & 0 & 0 \\
\hline Total & & & 13 & 100 \\
\hline Questão 13 & & & & \\
\hline Manter & & & 13 & 100 \\
\hline Excluir & & & 0 & 0 \\
\hline Alterar & & & 0 & 0 \\
\hline Total & & & 13 & 100 \\
\hline Questão 14 & & & & \\
\hline Manter & & & 13 & 100 \\
\hline Excluir & & & 0 & 0 \\
\hline Alterar & & & 0 & 0 \\
\hline Total & & & 13 & 100 \\
\hline Questão 15 & & & & \\
\hline Manter & & & 13 & 100 \\
\hline Excluir & & & 0 & 0 \\
\hline Alterar & & & 0 & 0 \\
\hline Total & & & 13 & 100 \\
\hline
\end{tabular}

Em relação aos comentários se o conjunto de questões apresentadas no instrumento é representativo frente ao universo teórico do processo de gerenciamento de custos realizados por enfermeiras em unidades hospitalares, $100 \%$ dos juízes responderam que sim, sendo que três especialistas solicitaram a inclusão de uma questão no item sobre condições institucionais.

No quadro abaixo foram agrupadas as sugestões dos juízes sobre a avaliação efetuada em relação aos conteúdos dos Itens.

\begin{tabular}{|l|c|l|}
\hline \multicolumn{1}{|c|}{ Itens } & $\mathbf{N}^{\mathbf{0}}$. de juízes & \multicolumn{1}{|c|}{ Sugestão } \\
\hline $\begin{array}{l}\text { Parte II } \\
\text { Práticas gerenciais }\end{array}$ & - & Não houve sugestões \\
\hline $\begin{array}{l}\text { Parte III } \\
\text { Conhecimento }\end{array}$ & 1 & $\begin{array}{l}\text { Acrescentar mais uma opção de resposta: ( ) } \\
\text { desconheço }\end{array}$ \\
\hline $\begin{array}{l}\text { Parte IV } \\
\begin{array}{l}\text { Condições } \\
\text { institucionais }\end{array}\end{array}$ & 3 & $\begin{array}{l}\text { Acrescentar uma questão: As enfermeiras sentem } \\
\text { falta desses dados (custos) para realização de sua } \\
\text { prática gerencial? }\end{array}$ \\
\hline
\end{tabular}

Figura 11 - Sugestões dos juízes no julgamento do questionário, São Paulo - 2011 
Quanto à sugestão de colocar a opção 'desconheço' como uma resposta, na parte III de conhecimento, o juiz justificou ser necessário para evitar que haja escolha de alternativas sem o conhecimento real da enfermeira, o que poderia comprometer a avaliação ao ser aplicado. A sugestão foi aceita.

Os três juízes que sugeriram acrescentar a questão relacionada à utilização ou não das informações de custos ou da realização orçamentária na prática gerencial apontaram que às vezes as enfermeiras recebem as informações, mas, não é solicitada nenhuma análise ou ação por parte delas. Esta sugestão não foi aceita no estudo, pois na parte II do instrumento há um espaço aberto em todas as questões para o sujeito do estudo explicar o porquê da resposta. Sendo assim, uma das respostas poderia ser sentir ou não sentir falta desses dados (custos) para realização da prática gerencial.

Assim, no que tange à pesquisa, este estudo possibilitou a disponibilização de um instrumento validado para que fosse aplicado empiricamente.

\subsection{PROCEDIMENTO PARA A COLETA DE DADOS}

Para a realização deste estudo, observou-se a Resolução 196/96 do Ministério da Saúde. O projeto foi encaminhado ao Comitê de Ética em Pesquisa (CEP) da Escola de Enfermagem da Universidade de São Paulo reconhecido pelo conselho Nacional de Pesquisa com Seres Humanos (CONEP) e foi aprovado em 10 de dezembro de 2009 (ANEXO A).

Em seguida o estudo foi encaminhado ao CEP da instituição $A$, também reconhecido pelo CONEP e foi aprovado em 20 de maio de 2011 (ANEXO B). A aprovação neste comitê permitiu a coleta de dados em ambas as instituições uma vez que a instituição B por ser uma organização social gerenciada pela Instituição A, pertence ao mesmo comitê.

No que diz respeito ao procedimento de coleta de dados, foram agendadas uma reunião com cada uma das gestoras das organizações hospitalares com a finalidade de esclarecer os objetivos do estudo e em seguida foi solicitada a autorização para a coleta de dados. O estudo foi 
iniciado somente após a autorização de ambas as gestoras e aprovação do CEP da instituição participante.

As enfermeiras, participantes, foram esclarecidas quanto aos objetivos do estudo, sua participação voluntária, a garantia do sigilo sobre suas respostas e pedido de preenchimento de Termo de Consentimento Livre e Esclarecido (TCLE) (APÊNDICE D), em duas vias, sendo que uma ficou com o sujeito da pesquisa e outra com o pesquisador.

Foram aplicados dois instrumentos do tipo A, um em cada instituição do estudo. Na Instituição $\mathrm{A}$, hospital privado, a enfermeira que respondeu a este questionário foi a coordenadora da divisão de clínica médica-cirúrgica e na Instituição B, organização social de saúde, foi a gerente de enfermagem.

Conforme dito anteriormente, a coleta dos dados referentes à participação das enfermeiras no gerenciamento de custos foi realizada mediante aplicação do instrumento B.

A pesquisadora apresentou-se às enfermeiras, orientou-as sobre o estudo, recebeu o consentimento de participação das mesmas e aplicou o questionário. O questionário foi entregue às enfermeiras e foi recolhido, respondido, após dois dias.

A coleta de dados foi realizada em maio e junho de 2011.

\subsection{APRESENTAÇÃO E ANÁLISE DOS RESULTADOS}

Foi criado um banco de dados utilizando a planilha eletrônica Excel 97, série Windows 98, para registro, tratamento e apresentação dos dados quantitativos em freqüências absolutas e relativas. Os dados foram apresentados na forma de tabelas e figuras.

Os dados quantitativos receberam tratamentos estatísticos para identificação de possíveis associações das variáveis e suas prováveis relações de co-variação. 
8 RESULTADOS E DISCUSSÃO 


\section{RESULTADOS E DISCUSSÃO}

A apresentação e discussão dos dados estão organizadas em sete subcapítulos. No primeiro, está demonstrada a análise do instrumento de coleta de dados A (APÊNDICE A), respondido somente por um profissional de cada instituição com a finalidade de caracterizar as organizações hospitalares e identificar as práticas de gestão de custos utilizadas pelos gestores.

No segundo, está caracterizada a amostra do estudo. Em seguida estão apresentados os dados referentes à avaliação do conteúdo das práticas gerenciais em custos.

O quarto subcapítulo apresenta o conhecimento das enfermeiras sobre os principais conceitos de custos hospitalares.

A seguir, no quinto, estão analisados os agrupamentos das questões sobre conhecimento geral de custos.

No próximo subcapítulo estão apresentados os dados referentes à participação das enfermeiras no gerenciamento de custos incluindo a análise das questões abertas.

E por fim está apresentada a comparação entre as duas instituições do estudo.

\subsection{CARACTERIZAÇÃO DAS INSTITUIÇÕES DE SAÚDE E PERFIL DAS GESTORAS DE ENFERMAGEM}

A Figura 12 apresenta o perfil das duas instituições estudadas, de acordo com as respostas das enfermeiras gestoras.

\begin{tabular}{|l|l|l|}
\hline & \multicolumn{1}{|c|}{ Instituição A } & \multicolumn{1}{c|}{ Instituição B } \\
\hline No. Leitos atuais & 780 & 230 \\
\hline Especialidades atendidas & $\begin{array}{l}\text { Cl.M, GO, PED, Cl.C, PS, } \\
\text { UTI, Cardio, ORT, ONCO }\end{array}$ & $\begin{array}{l}\text { Cl.M, GO, PED, CI.C, PS, } \\
\text { UTI, PQ, ORT }\end{array}$ \\
\hline Nível de referência & Quaternário & Secundário \\
\hline Natureza & Privada & Organização social \\
\hline Vínculo & Filantrópica & Público-privada \\
\hline
\end{tabular}

Figura 12 - Perfil das instituições de saúde do estudo, São Paulo - 2011

Legenda: CI.M: clínica médica, GO: ginecologia e obstetrícia, PED: pediatria, Cl.C: clínica cirúrgica, PS: pronto socorro (urgências e emergências), UTI: unidade de terapia intensiva, ORT: ortopedia, CARDIO: cardiologia, PQ: psiquiatria. 
A Figura 13 apresenta o perfil das gestoras.

\begin{tabular}{|l|l|l|}
\hline \multicolumn{1}{|c|}{ Instituição A } & \multicolumn{1}{c|}{ Instituição B } \\
\hline Gênero & \multicolumn{1}{|c|}{ Feminino } & Feminino \\
\hline Idade (anos) & 32 & 44 \\
\hline Tempo de formação (anos) & 10 & 22 \\
\hline $\begin{array}{l}\text { Tempo de atuação na } \\
\text { instituição (anos) }\end{array}$ & 8 & 3 \\
\hline Cargo ocupado & $\begin{array}{l}\text { Coordenadora } \\
\text { enfermagem }\end{array}$ & Gerente assistencial \\
\hline $\begin{array}{l}\text { Tempo de atuação no } \\
\text { cargo (anos) }\end{array}$ & 3 & 3 \\
\hline \begin{tabular}{l} 
Titulação \\
\hline
\end{tabular} & Especialista em oncologia & $\begin{array}{l}\text { Mestrado em gerenciamento } \\
\text { de enfermagem }\end{array}$ \\
\hline
\end{tabular}

Figura 13 - Perfil das gestoras da área de enfermagem das instituições de saúde do estudo, São Paulo - 2011

Nota-se que ambas são do gênero feminino, que corrobora com dados empíricos da prática dos profissionais de enfermagem, que em sua grande maioria são do gênero feminino. A idade é variada.

As duas enfermeiras possuem mais de dez anos de formada. Quanto ao tempo de atuação na instituição, ambas apresentam experiência no setor hospitalar, uma vez que referiram tempo de atuação há mais de três anos. Com relação ao tempo de atuação no cargo, ambas estão há três anos, o que refere um conhecimento diferenciado dos setores que gerenciam assim como as informações sobre o sistema de gerenciamento de custos utilizado.

A Figura 14, elaborada a partir das respostas das enfermeiras, mostra o conhecimento das gestoras sobre o gerenciamento de custos da instituição e sua participação no planejamento e nos orçamentos. 


\begin{tabular}{|c|c|c|}
\hline & Instituição A & Instituição B \\
\hline Possui gerenciamento de custos? & Sim & Sim \\
\hline Método de custeio utilizado & $\begin{array}{l}\text { Absorção por centro de } \\
\text { custo }\end{array}$ & Custeio direto/variável \\
\hline Tempo de implantação do método & Mais de 5 anos & 2 anos \\
\hline $\begin{array}{l}\text { Recebe informações sobre custos } \\
\text { do seu setor? }\end{array}$ & $\begin{array}{l}\text { Sim, em forma de } \\
\text { tabelas e gráficos }\end{array}$ & Sim \\
\hline $\begin{array}{l}\text { Estas informações são de fácil } \\
\text { compreensão? }\end{array}$ & $\begin{array}{l}\text { Sim, apresentadas em } \\
\text { tabelas }\end{array}$ & $\begin{array}{l}\text { Sim, procurei conhecer o } \\
\text { sistema }\end{array}$ \\
\hline $\begin{array}{l}\text { As unidades são organizadas } \\
\text { como centro de custos? }\end{array}$ & Sim & Sim \\
\hline $\begin{array}{l}\text { Atividades relacionadas à gestão } \\
\text { de custos (foram agregadas duas } \\
\text { questões } \mathrm{n}^{\circ} .6 \text { e } \mathrm{n}^{\circ} .9 \text { por } \\
\text { similaridade de respostas) }\end{array}$ & $\begin{array}{l}\text { Atuação somente na } \\
\text { gestão de materiais e } \\
\text { medicamentos, controle } \\
\text { de gastos do centro de } \\
\text { custo com despesas de } \\
\mathrm{RH}, \text { materiais, despesas } \\
\text { com treinamentos, } \\
\text { apoio financeiro para } \\
\text { cursos, desperdício de } \\
\text { medicamentos }\end{array}$ & $\begin{array}{l}\text { Acompanhamento de } \\
\text { custos e orçamentos, } \\
\text { controle de custos e } \\
\text { orçamento, } \\
\text { acompanhamento de } \\
\text { resultados alcançados e } \\
\text { produtividade }\end{array}$ \\
\hline $\begin{array}{l}\text { Conhecimento do orçamento do } \\
\text { serviço de enfermagem }\end{array}$ & Não & Sim \\
\hline $\begin{array}{llcl}\text { Participação } & \text { da } & \text { elaboração } & \text { do } \\
\text { orçamento } & \text { do } & \text { serviço } & \text { de } \\
\text { enfermagem } & & & \end{array}$ & Não & $\begin{array}{l}\text { Sim, porém é } \\
\text { estabelecido pela } \\
\text { Secretaria Municipal de } \\
\text { Saúde, pouco interfiro }\end{array}$ \\
\hline $\begin{array}{l}\text { Existem outras enfermeiras com } \\
\text { atividades relacionadas à gestão } \\
\text { de custos? }\end{array}$ & $\begin{array}{l}\text { Sim, cada coordenadora } \\
\text { de enfermagem é } \\
\text { responsável pelo seu } \\
\text { CC }\end{array}$ & $\begin{array}{lr}\text { Sim, todas } & \text { as } \\
\text { coordenadoras } & \text { de } \\
\text { enfermagem } & \text { são } \\
\text { responsáveis pelo } & \text { seu } \\
\text { CC } & \\
\end{array}$ \\
\hline $\begin{array}{l}\text { Gestão de custos é uma das } \\
\text { atividades das enfermeiras? }\end{array}$ & Sim & Sim \\
\hline $\begin{array}{l}\text { As enfermeiras estão capacitadas } \\
\text { para a gestão de custos na } \\
\text { instituição? }\end{array}$ & $\begin{array}{lrr}\text { Sim, mas estão } & \text { em } \\
\text { processo } & & \text { de } \\
\text { capacitação } & & \end{array}$ & $\begin{array}{l}\text { Não, somente as } \\
\text { coordenadoras que } \\
\text { ainda estão em fase de } \\
\text { aprendizagem }\end{array}$ \\
\hline
\end{tabular}

Figura 14 - Dados sobre gerenciamento de custos das instituições de saúde do estudo, São Paulo - 2011

Ressalta-se na figura apresentada que na Instituição $A$, a enfermeira respondeu que não possui conhecimento e não participa do orçamento do serviço de enfermagem. Esta enfermeira foi indicada pela gerente de enfermagem da instituição a responder o instrumento de coleta de dados $A$, por representá-la administrativamente. Neste caso, se esta enfermeira não possui tal conhecimento infere-se que os demais coordenadores de unidades também não conheçam o orçamento do serviço de enfermagem.

A falta de acesso às informações sobre tal orçamento acarreta em dificuldades de planejar o orçamento do setor em que esta enfermeira 
gerencia. Porém, a instituição cobra desta, um planejamento apurado, envolvendo custos. Há uma contradição aparente nesta instituição. Os dados precisam estar disponíveis aos profissionais que o utilizarão para fins administrativos na instituição.

\subsection{CARACTERIZAÇÃO DA AMOSTRA DO ESTUDO}

Foram pesquisadas duas instituições: Instituição A com 172 (92,0\%) enfermeiras e Instituição B com 15 (8,0\%) enfermeiras.

Assim, participaram do estudo 187 enfermeiras com idade entre $21 \mathrm{e}$ 53 anos com média de 32,92 anos (DP $\pm 6,56$ ) e mediana de 31 anos, sendo que $145(77,5 \%)$ profissionais eram do sexo feminino.

O gráfico abaixo apresenta a distribuição das enfermeiras avaliadas em relação à faixa etária.

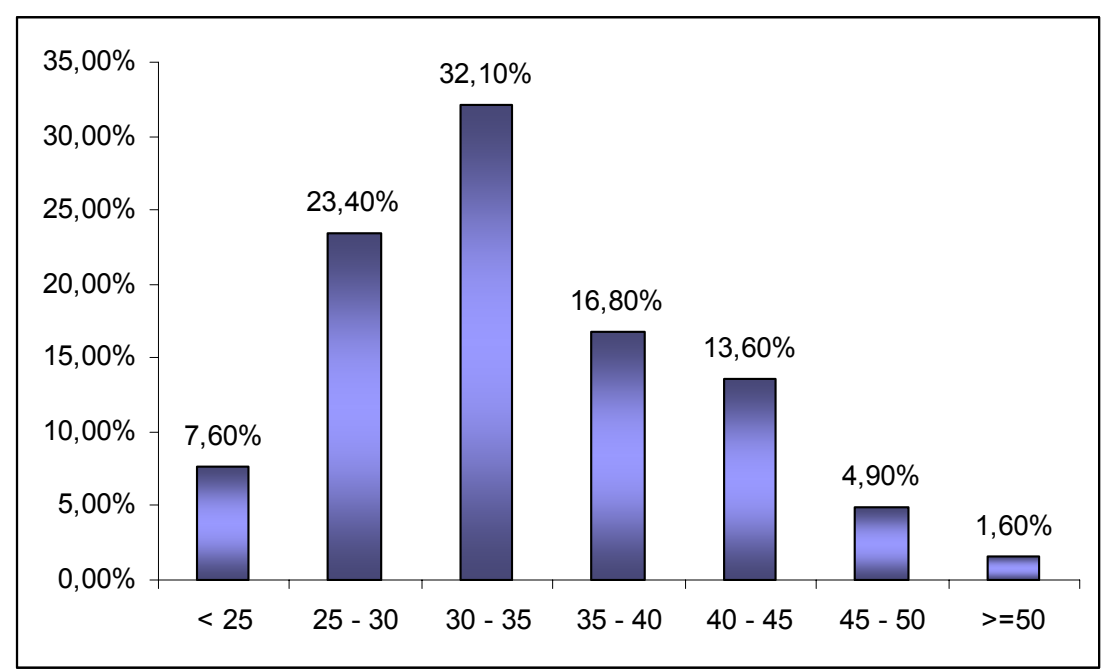

Figura 15 - Distribuição das enfermeiras segundo a faixa etária, São Paulo - 2011

O tempo de formação destas variou de um a 30 anos, média de 7,89 anos (DP $\pm 5,82$ ) e mediana de seis anos. O tempo de atuação na instituição variou de um a 30 anos com média de 6,28 anos (DP $\pm 4,90)$ e mediana de cinco anos.

$\mathrm{Na}$ tabela 2 apresenta-se a distribuição das enfermeiras segundo o cargo que ocupam e a titulação. 
Tabela 2 - Distribuição das 187 enfermeiras segundo o cargo e a titulação, São Paulo 2011

\begin{tabular}{llcc}
\hline Variável & Categoria & $\mathbf{N}$ & $\%$ \\
\hline \multirow{3}{*}{ Cargo } & Enf. Junior & 26 & 13,9 \\
& Enf. Pleno & 138 & 73,8 \\
& Enf. Sênior & 18 & 9,6 \\
& Enf. Auditor & 3 & 1,6 \\
& Coordenador & 2 & 1,1 \\
& & & \\
Titulação & Especialização & 161 & 86,1 \\
& Mestre & 7 & 3,7 \\
& Doutor & 0 & 0,0 \\
& Sem Titulo & 19 & 10,2 \\
\hline
\end{tabular}

A Figura 16 mostra a distribuição das 187 enfermeiras segundo os cargos ocupados.

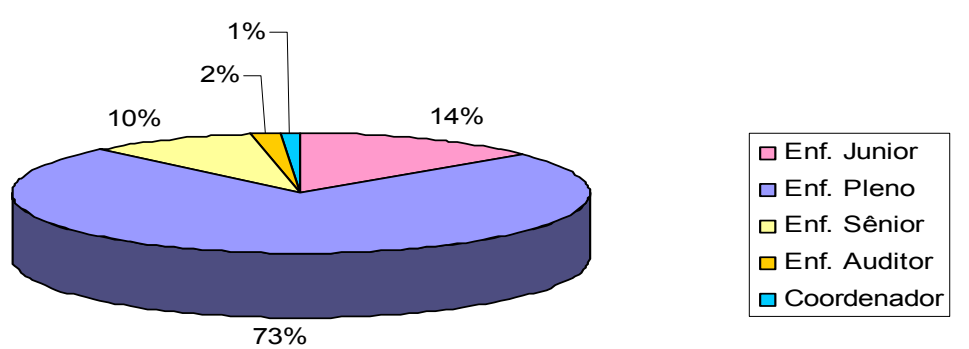

Figura 16 - Distribuição das enfermeiras segundo o cargo, São Paulo - 2011

O tempo de atuação no cargo variou de um a 30 anos, média de 5,80 anos (DP $\pm 4,63$ ) e mediana de 4,50 anos.

A categoria mais representativa foi das enfermeiras Plenas com 138 $(73,8 \%)$ enfermeiras, aqueles que atuam nas instituições tanto na assistência quanto na área administrativa, o que sugere uma atuação mais direta em relação ao gerenciamento de custos.

A instituição A classifica como enfermeira Plena a enfermeira que mediante avaliação de desempenho é promovida internamente, desde que seja enfermeira Junior e possua no mínimo seis meses de experiência. Ou ainda pode ser uma enfermeira contratada com no mínimo um ano de experiência externa. Esta profissional também desenvolve atividades de 
assistência integral ao paciente e agrega atividades de gerenciamento de sua equipe. Atua com carga horária diária de seis horas.

A característica destas enfermeiras é de atuarem tanto na assistência quanto na área administrativa do setor, e os dados mostraram que estas se encontram em maioria nas instituições de saúde.

Enfermeira Junior nesta instituição é aquela profissional recém formada que já era funcionária do hospital em outra categoria profissional. Para assumir esta função a enfermeira é submetida a um processo seletivo com prova escrita e entrevista e caso seja aprovada desenvolverá atividades de assistência integral ao paciente com carga horária diária de trabalho de seis horas.

Já a enfermeira Sênior é a profissional que por meio de processo seletivo interno assume esta função que além de desenvolver as atividades das enfermeiras descritas acima, agrega em sua função o papel de líder da equipe. Atua como uma referência para todos os membros da equipe no que se refere à assistência prestada ao paciente. Existe um número restrito de vagas para esta categoria de enfermeiras. Esta profissional trabalha oito horas diárias e sua escala de trabalho conta com folga em todos os domingos e plantões aos sábados a cada duas semanas.

$\mathrm{Na}$ instituição $\mathrm{B}$, a classificação das enfermeiras é semelhante à Instituição A, com algumas diferenças.

A instituição classifica enfermeira Junior como sendo aquela profissional recém formada que já era funcionária do hospital em outra categoria profissional ou enfermeira recém-formada. O processo seletivo é o mesmo da Instituição $A$.

Enfermeira Plena é a enfermeira que mediante sua avaliação de desempenho como enfermeira Junior é promovida internamente. Esta profissional também desenvolve atividades de assistência integral ao paciente e agrega atividades de gerenciamento de sua equipe.

A Figura 17 mostra a distribuição das 187 enfermeiras segundo as titulações. 


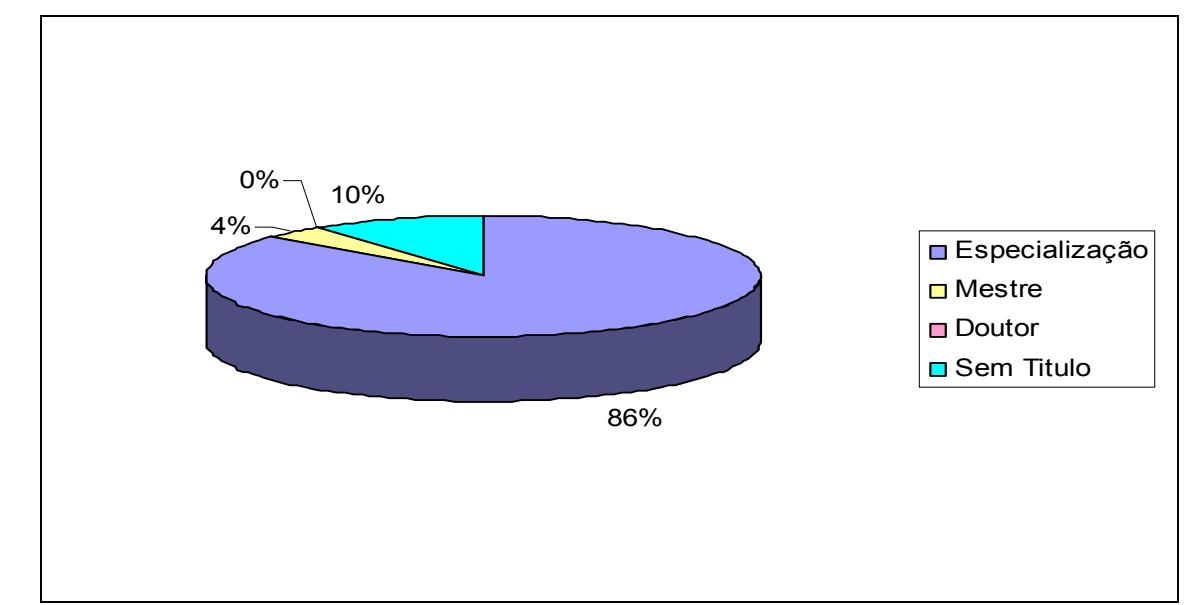

Figura 17 - Distribuição das enfermeiras segundo a titulação, São Paulo - 2011

Em relação à titulação, $161(86,1 \%)$ enfermeiras apresentam especialização lato senso, sete enfermeiras, aproximadamente 4\%, possuem mestrado, não há enfermeiras doutoras e 19 (10,2\%) não possuem nenhum tipo de especialização.

A tabela 3 apresenta a distribuição das 168 enfermeiras com titulação segundo a área. 
Tabela 3 - Distribuição das áreas de titulação das 168 enfermeiras, São Paulo - 2011

\begin{tabular}{lcc}
\hline \multicolumn{1}{c}{ Tipo } & N & \% \\
\hline Oncologia & 35 & 20,8 \\
UTI & 25 & 14,9 \\
Pediatria & 22 & 13,1 \\
Gerenciamento & 18 & 10,7 \\
Nefrologia & 12 & 7,1 \\
Cardiologia & 8 & 4,8 \\
Cmc & 8 & 4,8 \\
Geriatria & 7 & 4,2 \\
Emergência & 4 & 2,4 \\
Docência & 3 & 1,8 \\
Hematologia & 3 & 1,8 \\
Obstetrícia & 3 & 1,8 \\
Ostomia & 3 & 1,8 \\
Saúde coletiva & 3 & 1,8 \\
Infectologia & 2 & 1,2 \\
Auditoria & 1 & 0,6 \\
Centro cirúrgico & 1 & 0,6 \\
Centro diagnóstico & 1 & 0,6 \\
Dermatologia & 1 & 0,6 \\
Dor & 1 & 0,6 \\
Neurologia & 1 & 0,6 \\
Psiquiatria & 1 & 0,6 \\
Qualidade & 1 & 0,6 \\
Saúde mental & 1 & 0,6 \\
Trauma & 1 & 0,6 \\
Urologia & 1 & 0,6 \\
Sem resposta & 1 & 0,6 \\
\hline
\end{tabular}

Nota-se, pela análise da Tabela 3 que 35 (20,8\%) enfermeiras possuem especialização (28) ou mestrado (7) em oncologia. Não há nenhuma enfermeira com título de doutora.

Os setores utilizados para a coleta de dados nas instituições foram as clínicas médica e cirúrgica sendo que na Instituição A também são atendidos pacientes da oncologia, área muito específica, o que requer dos profissionais especialização e atualização na área. 


\subsection{AVALIAÇÃO DO CONTEÚDO DAS PRÁTICAS GERENCIAIS EM CUSTOS}

A Parte II do instrumento apresentou questões relacionadas à avaliação do conteúdo das práticas gerenciais em custos.

Estes profissionais foram questionados sobre as práticas gerenciais em custos com as seguintes questões:

8) Você conhece os custos do seu setor?

9) Você conhece o sistema de custeio utilizado no hospital em que atua para gerar os relatórios de custos dos serviços e procedimentos?

10) Você recebe relatórios periodicamente sobre os custos da sua unidade?

11) Você participa de reuniões periódicas para discussão da evolução dos custos do seu setor?

12) Você conhece o orçamento do serviço de enfermagem?

13) Você conhece o orçamento do setor que atua?

14) Você participa da elaboração do orçamento do setor que atua?

15) Você possui acesso às informações necessárias para a elaboração do orçamento do setor que atua?

16) Você conhece o faturamento do seu setor?

17) Você participa da elaboração de custos de procedimentos/ pacotes?

18) Você realiza outras atividades relacionada a custos em seu setor?

Na tabela abaixo apresentamos as freqüências absolutas e relativas das respostas de cada questão, observadas no grupo de 187 enfermeiras. 
Tabela 4 - Freqüências absolutas e relativas das respostas das questões 8 a 18, relativas às praticas gerenciais de custos, São Paulo - 2011

\begin{tabular}{|c|c|c|c|}
\hline Questão & Resposta & $\mathbf{N}$ & $\%$ \\
\hline \multirow[t]{2}{*}{8} & Sim & 49 & 26,2 \\
\hline & Não & 138 & 73,8 \\
\hline \multirow[t]{2}{*}{$9^{*}$} & Sim & 35 & 18,8 \\
\hline & Não & 151 & 81,2 \\
\hline \multirow[t]{2}{*}{$10^{*}$} & Sim & 25 & 13,4 \\
\hline & Não & 161 & 86,6 \\
\hline \multirow[t]{2}{*}{11} & Sim & 36 & 19,3 \\
\hline & Não & 151 & 80,7 \\
\hline \multirow[t]{2}{*}{$12^{*}$} & Sim & 19 & 10,2 \\
\hline & Não & 167 & 89,8 \\
\hline \multirow[t]{2}{*}{$13^{*}$} & Sim & 24 & 12,9 \\
\hline & Não & 162 & 87,1 \\
\hline \multirow[t]{2}{*}{14} & Sim & 19 & 10,2 \\
\hline & Não & 168 & 89,8 \\
\hline \multirow[t]{2}{*}{$15^{*}$} & Sim & 15 & 8,1 \\
\hline & Não & 171 & 91,9 \\
\hline \multirow[t]{2}{*}{16} & Sim & 15 & 8,0 \\
\hline & Não & 172 & 92,0 \\
\hline \multirow[t]{2}{*}{$17^{*}$} & Sim & 12 & 6,5 \\
\hline & Não & 174 & 93,5 \\
\hline \multirow[t]{2}{*}{$18^{* *}$} & Sim & 29 & 15,7 \\
\hline & Não & 156 & 84,3 \\
\hline
\end{tabular}

$\left(^{*}\right) 1$ enfermeira não respondeu a esta questão

$\left.{ }^{(* *}\right) 2$ enfermeiras não responderam a esta questão

A análise dos dados da tabela 4 mostra que em todas as questões 0 maior percentual encontrado foi para a resposta "não", variando de $73,8 \%$ (138 enfermeiras) na questão oito a 93,5\% (174 enfermeiras) na questão 17.

Neste bloco de questões sobre avaliação do conteúdo das práticas gerenciais, muitas enfermeiras responderam não às perguntas e como justificativas colocaram a falta de acesso ou informação para desempenho 
da atividade relacionada à pergunta (Tabela 5). Um percentual inferior, menos de $7 \%$, justificou que era uma atribuição do coordenador.

Tabela 5 - Freqüências absolutas e relativas das justificativas das questões relativas às praticas gerenciais de custos, São Paulo - 2011

\begin{tabular}{|c|c|c|c|c|c|c|c|c|c|c|c|c|}
\hline \multirow[b]{4}{*}{ Questão } & \multicolumn{12}{|c|}{ Resposta } \\
\hline & \multicolumn{4}{|c|}{ Sim } & \multicolumn{8}{|c|}{ Não } \\
\hline & \multicolumn{2}{|c|}{$\begin{array}{c}\text { Preocupação } \\
\text { com } \\
\text { desperdício }\end{array}$} & \multicolumn{2}{|c|}{$\begin{array}{c}\text { Não } \\
\text { justificado }\end{array}$} & \multicolumn{2}{|c|}{$\begin{array}{c}\text { Atribuição } \\
\text { do } \\
\text { coordenador }\end{array}$} & \multicolumn{2}{|c|}{$\begin{array}{c}\text { Falta de } \\
\text { acesso ou } \\
\text { informação }\end{array}$} & \multicolumn{2}{|c|}{$\begin{array}{l}\text { Não é } \\
\text { norma }\end{array}$} & \multicolumn{2}{|c|}{$\begin{array}{c}\text { Não } \\
\text { justificado }\end{array}$} \\
\hline & $\mathbf{N}$ & $\%$ & $\mathbf{N}$ & $\%$ & $\mathbf{N}$ & $\%$ & $\mathbf{N}$ & $\%$ & $\mathbf{N}$ & $\%$ & $\mathbf{N}$ & $\%$ \\
\hline 8 & 0 & 0,0 & 49 & 100,0 & 7 & 5,1 & 54 & 39,1 & 0 & 0,0 & 77 & 55,8 \\
\hline 9 & 0 & 0,0 & 35 & 100,0 & 6 & 4,0 & 52 & 34,4 & 1 & 0,7 & 92 & 60,9 \\
\hline 10 & 0 & 0,0 & 25 & 100,0 & 10 & 6,2 & 48 & 29,8 & 1 & 0,6 & 102 & 63,4 \\
\hline 11 & 2 & 5,6 & 34 & 94,4 & 8 & 5,3 & 43 & 28,5 & 0 & 0,0 & 100 & 66,2 \\
\hline 12 & 0 & 0,0 & 19 & 100,0 & 5 & 3,0 & 47 & 28,1 & 0 & 0,0 & 115 & 68,9 \\
\hline 13 & 0 & 0,0 & 24 & 100,0 & 6 & 3,7 & 45 & 27,8 & 0 & 0,0 & 111 & 68,5 \\
\hline 14 & 1 & 5,3 & 18 & 94,7 & 9 & 5,4 & 48 & 28,6 & 0 & 0,0 & 111 & 66,1 \\
\hline 15 & 0 & 0,0 & 15 & 100,0 & 7 & 4,1 & 44 & 25,7 & 0 & 0,0 & 120 & 70,2 \\
\hline 16 & 0 & 0,0 & 15 & 100,0 & 7 & 4,1 & 45 & 26,2 & 0 & 0,0 & 120 & 69,8 \\
\hline 17 & 0 & 0,0 & 12 & 100,0 & 12 & 6,9 & 42 & 24,1 & 0 & 0,0 & 120 & 69,0 \\
\hline 18 & 6 & 20,7 & 23 & 79,3 & 7 & 4,5 & 38 & 24,4 & 0 & 0,0 & 111 & 71,2 \\
\hline
\end{tabular}

Estas questões foram elaboradas com a finalidade de identificar as práticas gerenciais relacionadas a custos, desenvolvidas pelas enfermeiras que atuam tanto na assistência quanto na administração dos setores hospitalares. Pelas respostas negativas identificou-se que mais de $73 \%$ das enfermeiras não exercem participação e/ou não possuem acesso às informações necessárias para o desenvolvimento do gerenciamento de custos.

Estudos realizados explicam que, entre tantas tendências para o gerenciamento de serviços de enfermagem, uma delas é a inclusão de conhecimentos e desenvolvimento de habilidades sobre custos, ferramenta utilizada nos processos de tomada de decisão ${ }^{(53,54)}$. Porém os dados encontrados neste estudo mostraram oposição aos achados na literatura.

A enfermeira necessita de conhecimentos sobre custos, de acesso às informações e de habilidades para a boa prática gerencial relacionada a custos. A ausência de um dos itens acima compromete tal prática e percebese hoje em dia que as enfermeiras ao referirem conhecer as práticas gerenciais estão relatando, na verdade, o conhecimento somente da gestão 
de materiais e suprimentos e não efetivamente o acompanhamento de planilhas com informações sobre custos.

Tal afirmação corrobora com os dados encontrados na questão 8, sobre o conhecimento dos custos do setor, na qual 138 (73,8\%) enfermeiras relataram que desconhecem, pois não têm acesso ou que a informação não é divulgada.

O conhecimento sobre os custos do setor é uma questão que precisa ser averiguada, pois as enfermeiras que não possuírem domínio do uso das ferramentas de custos encontrarão dificuldades para administrar de forma competitiva seus setores principalmente em relação às perdas geradas ${ }^{(15)}$.

No que se refere à questão sobre o conhecimento do sistema de custeio utilizado no hospital, sistema que gera os relatórios de custos dos serviços e procedimentos, 151 (81,2\%) enfermeiras responderam que não conhecem e, ainda, complementaram que não possuem acesso às informações necessárias.

A questão 10 levantou se a enfermeira recebe relatórios periodicamente sobre os custos da sua unidade, e mais uma vez, o percentual de respostas negativas foi muito superior ao de respostas afirmativas, respectivamente $161(86,6 \%)$ e $25(13,4 \%)$ enfermeiras.

Estes resultados complementam os anteriores afirmando que as informações que as enfermeiras deveriam receber para gerenciar custos dos setores em que atuam não são completas ou não existem, o que impossibilita ainda mais o desempenho desta atividade.

Conclui-se, pelo percentual baixo para respostas afirmativas que não basta somente receber as informações nos relatórios, é necessária a compreensão da finalidade destes dados a fim de transformar os dados recebidos em informações importantes para a tomada de decisão no gerenciamento da unidade.

As enfermeiras são cobradas diariamente e de maneira incisiva, a manter a qualidade da assistência prestada prezando o menor custo possível para a instituição. A maioria destas profissionais relata a falta de conhecimento ou de habilidades relacionadas à gestão de custos. 
Com a finalidade de discutir mais o assunto e suprindo as necessidades de cada enfermeira, foi elaborada a questão seguinte para identificar se as profissionais participam de reuniões periódicas para expor as dificuldades tendo em vista a pressão sofrida por manter custos reduzidos.

Os resultados encontrados foram que 151 (80,7\%) enfermeiras referiram que não participam destas reuniões ou porque não são convidadas ou porque elas não existem. Participaram de reuniões 36 (19,3\%) enfermeiras e destas, duas (5,5\%) discutem assuntos relacionados a desperdício de materiais.

Nas duas questões seguintes, foi abordado o assunto orçamento. Com relação ao conhecimento do orçamento do serviço de enfermagem, somente 19 (10,2\%) enfermeiras responderam afirmativamente. E sobre o conhecimento do orçamento do setor que atuam 24 (12,9\%) enfermeiras referiram conhecê-lo.

Ou seja, os dados mostram que menos de 13\% das enfermeiras conhecem o orçamento do setor que atuam e do serviço de enfermagem. Os resultados encontrados corroboram com estudo que refere que embora estas profissionais estejam envolvidas e inseridas em instituições hospitalares com centros de custos bem estruturados, as mesmas ainda não se encontram envolvidas o suficiente para entenderem a importância dos dados sobre custos e de como fazer disso uma ferramenta para a prática profissional uma vez que a maioria das enfermeiras desta pesquisa, nem o orçamento do setor onde atuam, conhece ${ }^{(15)}$.

O primeiro passo para compreender e organizar os dados referentes a custos é conhecer os custos do setor onde a enfermeira atua. É impossível tomar alguma medida decisória sem este conhecimento. É preciso conhecer o todo para avaliar o específico, ou seja, é importante e essencial conhecer o orçamento do setor onde a enfermeira atua para tomar decisões referentes à contenção de gastos, por exemplo, com desperdício de luvas.

Apenas $19(10,2 \%)$ enfermeiras apontaram que participam da elaboração do orçamento do setor que atuam, são as mesmas que responderam que conhecem o orçamento do serviço de enfermagem. Houve 
somente um comentário nesta questão de uma enfermeira da instituição B que referiu que participa da elaboração do orçamento somente na área de consumo de materiais.

Autores afirmam que é comum encontrar a enfermeira assessorando a área administrativa para obter resultados em seus aspectos técnicos no que se refere à aquisição de materiais e equipamentos ${ }^{(55)}$.

Tendo em vista que a exigência atual em um mercado altamente competitivo, no qual a enfermeira deve possuir conhecimento sobre orçamentos e custos para o adequado gerenciamento do seu setor, os dados encontrados estão muito abaixo desta necessidade, ficando a responsabilidade deste gerenciamento ainda a cargo dos gestores hospitalares.

O percentual encontrado referente ao desconhecimento do orçamento do setor que atua justifica as respostas para a próxima questão, sobre o acesso às informações necessárias para a elaboração do orçamento do setor, onde $171(91,9 \%)$ enfermeiras responderam que não possuem este acesso.

Não há possibilidade alguma de despertar interesse nas enfermeiras em gerenciar custos se as informações mínimas necessárias para tal não são de fácil acesso. Além disso, é preciso desenvolver habilidade em trabalhar com estas informações para adquirir confiança em apresentá-las aos gestores responsáveis.

Os resultados se mantêm de maneira negativa para a próxima questão sobre faturamento do setor, pois somente 15 (8\%) enfermeiras demonstraram possuir tal conhecimento.

As enfermeiras são profissionais que devido à natureza do seu trabalho, geram gastos, mas também, receita às organizações de saúde. Transformar a assistência em um serviço rentável é o objetivo destas instituições de saúde, mas para isso é preciso que os profissionais que estão à frente da assistência tenham conhecimento sobre custos, sobre as receitas e faturamento do setor de atuação, para com isso, junto com as suas chefias, proporem medidas de contenção de gastos e elevação de receitas. 
O desconhecimento dos custos pode acarretar análises errôneas sobre os gastos dos setores e, muitas vezes, como conseqüência, tomadas de decisões inapropriadas às situações existentes.

As instituições do estudo trabalham com sistemas de pacotes de serviços/procedimentos, nos quais é pré-estabelecido um valor para cada procedimento baseado no custo do mesmo na determinada instituição. Por isso, foi perguntado na questão 17 , se a enfermeira participa da elaboração de custos de procedimentos/ pacotes. Obeteve-se nesta questão o menor percentual de respostas afirmativas entre as questões, pois somente 12 $(6,5 \%)$ enfermeiras relataram que participaram alguma vez desta atividade.

Ao fim deste bloco de questões foi perguntado se a enfermeira realiza outras atividades relacionadas a custos em seu setor e como nas demais questões somente um percentual pequeno, $29(15,7 \%)$ enfermeiras, responderam afirmativamente. Destas 29 enfermeiras, 28 são da Instituição A sendo que destas cinco responderam que realizam atividades relacionadas com desperdício de material. Houve uma enfermeira da Instituição B que apresentou a mesma justificativa.

Um estudo realizado em instituições hospitalares no ano de 2008 coloca que a administração hospitalar exerce forte influência no gerenciamento de custos, pois cobra das enfermeiras atitudes de eficiência e eficácia nas ações prestadas ${ }^{(56)}$.

Como cobrar das enfermeiras algo se não lhes é permitido o acesso às informações necessárias para o cumprimento das solicitações? Fica em aberto esta questão, que no entendimento da pesquisadora é o ponto chave para a compreensão da participação das enfermeiras na gestão de custos hospitalares. 


\subsection{CONHECIMENTO DAS ENFERMEIRAS SOBRE OS PRINCIPAIS CONCEITOS DE CUSTOS HOSPITALARES}

Nas tabelas a seguir apresentamos as repostas obtidas relativas à parte III do instrumento, conhecimento das enfermeiras sobre principais conceitos de custos hospitalares.

Para cada questão será apresentada uma tabela com os resultados respondidos pelas enfermeiras e ao final das análises individuais serão apresentadas outras tabelas que referenciam o percentual de acertos por grupo de questões, sugerindo a avaliação do conhecimento destas enfermeiras.

Questão 19) A aquisição de materiais e medicamentos pelo hospital com a finalidade de gerar assistência hospitalar é?

Tabela 6 - Distribuição de freqüências das 187 enfermeiras, segundo as respostas da questão 19, São Paulo - 2011

\begin{tabular}{ccc}
\hline Resposta & N & \% \\
\hline Custo & 58 & 31,0 \\
Gasto & 15 & 8,0 \\
Despesa & 25 & 13,4 \\
Investimento & 62 & 33,2 \\
Desconheço & 25 & 13,4 \\
Sem resposta & 2 & 1,1 \\
\hline
\end{tabular}

A resposta correta para esta questão é GASTO. Observamos pela tabela acima que somente $15(8,0 \%)$ enfermeiras acertaram a resposta correta, menor percentual de resposta correta.

O conceito de gasto segundo Martins ${ }^{(11)}$ apresentado no capítulo 3 deste estudo é "o sacrifício financeiro com que a entidade arca para a obtenção de um produto ou serviço qualquer, sacrifício esse apresentado por entrega ou promessa de entrega de ativos". Ou seja, é todo o esforço que a empresa faz para a aquisição de algo como, por exemplo, gasto com a compra de insumos.

Este é um conceito básico para a contabilidade de custos; é o ponto de partida para o entendimento das planilhas e orçamentos institucionais e 
com este resultado, percebe-se que poucas são as enfermeiras que conhecem tal conceito.

De acordo com a prática profissional e experiência da autora, as enfermeiras estão mais habituadas com a palavra custo do que com a palavra gasto e na maioria das vezes confundem os conceitos. Este resultado é demonstrado na tabela acima quando 58 (31\%) enfermeiras responderam custo como alternativa correta para esta questão.

Questão 20) A mão de obra utilizada direta ou indiretamente na prestação da assistência de enfermagem é?

Tabela 7 - Distribuição de freqüências das 187 enfermeiras, segundo as respostas da questão 20, São Paulo - 2011

\begin{tabular}{ccc}
\hline Resposta & N & \% \\
\hline Custo & 63 & 33,7 \\
Gasto & 23 & 12,3 \\
Despesa & 33 & 17,6 \\
Investimento & 41 & 21,9 \\
Desconheço & 25 & 13,4 \\
Sem resposta & 2 & 1,1 \\
\hline
\end{tabular}

Para esta questão, foi considerada como correta a enfermeira que assinalou a resposta CUSTO. Observamos pela tabela acima que menos da metade das enfermeiras, $63(33,7 \%)$, acertaram a resposta correta.

Ainda nesta questão houve um número expressivo de enfermeiras que indicaram investimento como alternativa correta, 41 (21,9\%). No capítulo 3 , apresento o conceito de investimento que difere totalmente do conceito de custo. Investimento é um tipo de gasto e não de custo.

Ainda houve enfermeiras que desconhecem este conceito, 122 $(65,2 \%)$. 
Questão 21) Os valores referentes ao rateio de água, energia elétrica, depreciação de equipamentos são?

Tabela 8 - Distribuição de freqüências das 187 enfermeiras, segundo as respostas da questão 21, São Paulo - 2011

\begin{tabular}{lll}
\hline Resposta & N & \% \\
\hline Gasto & 35 & 18,7 \\
Custo & 30 & 16,0 \\
Despesa & 69 & 36,9 \\
Perda & 15 & 8,0 \\
Desconheço & 34 & 18,2 \\
Sem resposta & 4 & 2,1 \\
\hline
\end{tabular}

Observamos pela tabela acima que somente $30(16,0 \%)$ enfermeiras acertaram a resposta correta, CUSTO. Observa-se que 69 (36,9\%) enfermeiras responderam despesa para esta questão. Porém o conceito de despesa difere do conceito de custos indiretos, entre eles, rateio de água, como exemplificado na questão.

Questão 22) Um sacrifício financeiro que a instituição tem para a obtenção de um produto ou serviço é?

Tabela 9 - Distribuição de freqüências das 187 enfermeiras, segundo as respostas da questão 22, São Paulo - 2011

\begin{tabular}{ccc}
\hline Resposta & N & \% \\
\hline Gasto & 50 & 26,7 \\
Custo & 42 & 22,5 \\
Despesa & 35 & 18,7 \\
Perda & 23 & 12,3 \\
Desconheço & 34 & 18,2 \\
Sem resposta & 3 & 1,6 \\
\hline
\end{tabular}

O percentual de acerto para esta questão de acordo com a tabela acima foi de $26,7 \%$, ou seja, somente 50 enfermeiras acertaram a resposta correta GASTO. Mesmo sendo um percentual inferior ao esperado, esta foi a alternativa com maior número de respostas corretas das enfermeiras. 
Questão 23) O desenvolvimento de programas de treinamento e desenvolvimento para os funcionários do hospital, assim como a aquisição de um bisturi cirúrgico elétrico são?

Tabela 10 - Distribuição de freqüências das 187 enfermeiras, segundo as respostas da questão 23, São Paulo - 2011

\begin{tabular}{ccc}
\hline Resposta & N & \% \\
\hline Custo & 11 & 5,9 \\
Gasto & 14 & 7,5 \\
Despesa & 8 & 4,3 \\
Investimento & 119 & 63,6 \\
Desconheço & 33 & 17,6 \\
Sem resposta & 2 & 1,1 \\
\hline
\end{tabular}

Observamos pela tabela acima que mais da metade das enfermeiras, $119(63,6 \%)$ acertaram a resposta correta, INVESTIMENTO. O conceito de investimento aproxima-se mais da realidade dos profissionais independente da área de atuação uma vez que, mercados como o bancário e o imobiliário, usufruem deste conceito. Infere-se, portanto que há maior chance de acerto nesta questão devido à formulação do enunciado, que refere "aquisição de um bem".

Questão 24) Gastos anormais, involuntários que ocorrem na instituição gerando ou não a assistência ao paciente é?

Tabela 11 - Distribuição de freqüências das 187 enfermeiras, segundo as respostas da questão 24, São Paulo - 2011

\begin{tabular}{ccc}
\hline Resposta & N & \% \\
\hline Custo & 15 & 8,0 \\
Gasto & 40 & 21,4 \\
Despesa & 35 & 18,7 \\
Perda & 67 & 35,8 \\
Desconheço & 29 & 15,5 \\
Sem resposta & 1 & 0,5 \\
\hline
\end{tabular}

A tabela acima apresenta o resultado de 67 (35,8\%) enfermeiras que acertaram a resposta correta, PERDA. As demais respostas tiveram percentuais inferiores ao da resposta correta, mas ainda assim, menos da metade das enfermeiras acertaram a resposta. 
Com relação à avaliação das questões de conhecimento geral sobre custos, 19 a 24, poucas enfermeiras acertaram os conceitos. Considerando que as instituições hospitalares estudadas possuem centros de custos estruturados, os resultados mostraram que as enfermeiras não estão envolvidas o necessário no gerenciamento de custos apesar de referirem que atuam diretamente na área, pois é uma cobrança das instituições.

Um estudo refere que apesar das enfermeiras estarem expostas constantemente ao assunto, não estão envolvidas o suficiente para entenderem a importância dos custos e os utilizarem como uma ferramenta para a prática profissional ${ }^{(15)}$.

Questão 25) Nas planilhas de custos dos setores, quando identificamos os custos referentes aos salários de funcionários, este custo é?

Tabela 12 - Distribuição de freqüências das 187 enfermeiras, segundo as respostas da questão 25, São Paulo - 2011

\begin{tabular}{ccc}
\hline Resposta & N & \% \\
\hline Direto & 95 & 50,8 \\
Indireto & 32 & 17,1 \\
Desconheço & 57 & 30,5 \\
Sem resposta & 3 & 1,6 \\
\hline
\end{tabular}

A resposta correta para esta questão é DIRETO e observamos pela tabela acima que $95(50,8 \%)$ enfermeiras acertaram a resposta. Mas ainda há um percentual diferenciado de enfermeiras, $89(47,6 \%)$, que desconhecem o conceito.

Questão 26) Nas planilhas de custos dos setores, quando identificamos os custos que utilizam as bases de rateio, estes custos são?

Tabela 13 - Distribuição de freqüências das 187 enfermeiras, segundo as respostas da questão 26, São Paulo - 2011

\begin{tabular}{ccc}
\hline Resposta & N & \% \\
\hline Direto & 27 & 14,4 \\
Indireto & 94 & 50,3 \\
Desconheço & 62 & 33,2 \\
Sem resposta & 4 & 2,1 \\
\hline
\end{tabular}


Observamos pela tabela acima que 94 (50,3\%) enfermeiras acertaram a resposta correta, INDIRETO. Mais da metade da amostra acertou esta questão, contudo um percentual diferenciado, 89 (47,6\%) enfermeiras desconhecem o conceito.

Questão 27) Os custos inerentes à produção dos serviços hospitalares que variam de acordo com a produção são custos?

Tabela 14 - Distribuição de freqüências das 187 enfermeiras, segundo as respostas da questão 27, São Paulo - 2011

\begin{tabular}{ccc}
\hline Resposta & N & \% \\
\hline Fixo & 28 & 15,0 \\
Variável & 100 & 53,5 \\
Desconheço & 51 & 27,3 \\
Sem resposta & 8 & 4,3 \\
\hline
\end{tabular}

Na tabela 14 observou-se que 100 (53,5\%) enfermeiras acertaram a resposta correta, VARIÁVEL, representaram mais da metade da amostra.

Questão 28) Os custos operacionais relacionados por exemplo à infraestrutura, e que permanecem constantes independente da demanda são custos?

Tabela 15 - Distribuição de freqüências das 187 enfermeiras, segundo as respostas da questão 28, São Paulo - 2011

\begin{tabular}{ccc}
\hline Resposta & N & \% \\
\hline Fixo & 85 & 45,5 \\
Variável & 50 & 26,7 \\
Desconheço & 47 & 25,1 \\
Sem resposta & 5 & 2,7 \\
\hline
\end{tabular}

Conforme demonstrado na tabela 15, 85 (45,5\%) enfermeiras acertaram esta questão, sendo a resposta correta, FIXO.

No que se refere à avaliação das questões sobre as classificações dos custos, 25 a 28, mais da metade da amostra de enfermeiras acertaram os conceitos.

A compreensão e o discernimento sobre as classificações dos custos são inerentes ao gerenciamento de custos uma vez que há necessidade de 
possuir estes conceitos claros e bem definidos para que sejam utilizados de maneira adequada nas instituições.

Autores ainda complementam que há uma necessidade elevada das enfermeiras pela busca de conhecimento sobre custos, por estarem engajadas no processo gerencial das instituições hospitalares e por visarem as tomadas de decisão em relação a uma eficiente racionalização dos recursos disponíveis com o objetivo de alcançar resultados coerentes com as necessidades da clientela e também da instituição ${ }^{(12)}$.

Questão 29) Para realizar o cálculo estimado dos custos indiretos relacionados à assistência prestada ao paciente utilizamos qual critério?

Tabela 16 - Distribuição de freqüências das 187 enfermeiras, segundo as respostas da questão 29, São Paulo - 2011

\begin{tabular}{ccc}
\hline Resposta & N & $\%$ \\
\hline Gasto & 26 & 13,9 \\
Despesa & 23 & 12,3 \\
Bases de Rateio & 69 & 36,9 \\
Não há critério, utilizam-se os próprios custos indiretos & 19 & 10,2 \\
Desconheço & 46 & 24,6 \\
Sem resposta & 4 & 2,1 \\
\hline
\end{tabular}

A tabela acima mostra que 69 (36,9\%) enfermeiras acertaram a resposta correta, que para realizar o cálculo estimado dos custos indiretos deve ser utilizado o critério bases de rateio.

Houve uma resposta nesta questão que chama atenção, pois 19 $(10,2 \%)$ enfermeiras responderam que não há critério para o cálculo estimado dos custos indiretos. Não era esperado este resultado uma vez que a melhor maneira de apropriar os custos indiretos nos métodos de custeio mais utilizados é o rateio.

Em qualquer método de custeio é utilizada a base de rateio para apropriar os custos não passíveis de apropriação direta. 
Questão 30) A unidade mínima onde se dá a acumulação de custos, é denominada:

Tabela 17 - Distribuição de freqüências das 187 enfermeiras, segundo as respostas da questão 30, São Paulo - 2011

\begin{tabular}{ccc}
\hline Resposta & $\mathbf{N}$ & $\mathbf{\%}$ \\
\hline Centro de custo & 90 & 48,1 \\
Unidade de produção & 23 & 12,3 \\
Centro de negócio & 19 & 10,2 \\
Centro de custo improdutivo & 7 & 3,7 \\
Desconheço & 42 & 22,5 \\
Sem resposta & 6 & 3,2 \\
\hline
\end{tabular}

Para esta questão foi considerada como correta a resposta CENTRO DE CUSTO e a tabela acima apresenta o resultado de que 90 (48,1\%) enfermeiras acertaram a resposta correta.

Questão 31) O setor hospitalar que atua diretamente na prestação da assistência ao paciente é um:

Tabela 18 - Distribuição de freqüências das 187 enfermeiras, segundo as respostas da questão 31, São Paulo - 2011

\begin{tabular}{ccc}
\hline Resposta & N & \% \\
\hline Centro de custo & 46 & 24,6 \\
Unidade de produção & 57 & 30,5 \\
Centro de custo produtivo & 33 & 17,6 \\
Centro de custo auxiliar & 7 & 3,7 \\
Desconheço & 38 & 20,3 \\
Sem resposta & 6 & 3,2 \\
\hline
\end{tabular}

A resposta correta nesta questão é CENTRO DE CUSTO PRODUTIVO, porém houve um percentual pequeno de acertos entre as enfermeiras, apenas $33(17,6 \%)$ acertaram a resposta correta. Obteve-se mais respostas incorretas do que corretas nesta questão. 
Questão 32) O setor hospitalar que atua indiretamente na prestação da assistência ao paciente é um:

Tabela 19 - Distribuição de freqüências das 187 enfermeiras, segundo as respostas da questão 32, São Paulo - 2011

\begin{tabular}{ccc}
\hline Resposta & N & \% \\
\hline Centro de custo & 19 & 10,2 \\
Unidade de produção & 25 & 13,4 \\
Centro de custo produtivo & 28 & 15,0 \\
Centro de custo auxiliar & 46 & 24,6 \\
Desconheço & 59 & 31,6 \\
Sem resposta & 10 & 5,3 \\
\hline
\end{tabular}

Observamos pela tabela 18 que 46 (24,6\%) enfermeiras acertaram a resposta correta, CENTRO DE CUSTO AUXILIAR. O maior percentual de enfermeiras assinalou que desconhecia o conceito, foram 59 (31,6\%) enfermeiras.

Questão 33) O que é um método de custeio?

Tabela 20 - Distribuição de freqüências das 187 enfermeiras, segundo as respostas da questão 33, São Paulo - 2011

\begin{tabular}{ccc}
\hline Resposta & N & $\%$ \\
\hline Método de apropriação de custos & 70 & 37,4 \\
Método de cálculo dos custos diretos & 37 & 19,8 \\
Método de cálculo indireto dos custos & 17 & 9,1 \\
Desconheço & 59 & 31,6 \\
Sem resposta & 4 & 2,1 \\
\hline
\end{tabular}

Nesta questão, $70(37,4 \%)$ enfermeiras acertaram a resposta correta, MÉTODO DE APROPRIAÇÃO DE CUSTOS. 


\subsection{ANÁLISE DOS AGRUPAMENTOS DE QUESTÕES SOBRE CONHECIMENTO GERAL SOBRE CUSTOS}

Para uma análise mais apurada dos acertos referentes à parte III do instrumento, conhecimento sobre conceitos de custos, foi realizado um agrupamento das questões 19 a 33, do seguinte modo:

- conhecimento geral sobre custos: questões 19 a 33

- conhecimento sobre conceitos de custos: questões 19 a 24

- conhecimento sobre classificação de custos: questões 25 a 28

- conhecimento sobre departamentalização de custos: questões 29 a 32

- conhecimento sobre metodologia de apropriação de custos: questão 33 (já analisada na Tabela 20)

Com estes agrupamentos temos:

Tabela 21 - Freqüências absolutas e relativas do número de acertos nas questões 19 a 33 referentes ao conhecimento geral sobre custos, São Paulo - 2011

\begin{tabular}{ccc}
\hline $\begin{array}{c}\text { Número de questões } \\
\text { corretas }\end{array}$ & $\mathbf{N}$ & $\%$ \\
\hline 0 & 17 & 9,1 \\
1 & 10 & 5,3 \\
2 & 4 & 2,1 \\
3 & 17 & 9,1 \\
4 & 19 & 10,2 \\
5 & 29 & 15,5 \\
6 & 15 & 8,0 \\
7 & 29 & 15,5 \\
8 & 12 & 6,4 \\
9 & 14 & 7,5 \\
10 & 12 & 6,4 \\
11 & 7 & 3,7 \\
12 & 2 & 1,1 \\
\hline
\end{tabular}

Como a parte III do instrumento foi constituída de 15 questões alternativas, foi definido pela pesquisadora como conhecimento mínimo sobre o assunto quando o sujeito acerta pelo menos $50 \%$ das questões.

Por ser um número ímpar, 15 questões, considerou-se então conhecimento mínimo aquelas enfermeiras que acertaram sete ou mais questões. A tabela acima mostrou que $76(40,6 \%)$ enfermeiras tiveram o acerto considerado e $111(59,4 \%)$ enfermeiras não tiveram o acerto. 
Estas 76 enfermeiras farão parte do grupo acerto, nomenclatura que será utilizada nesta análise.

Tabela 22 - Freqüências absolutas e relativas do número de questões corretas em cada agrupamento, São Paulo - 2011

\begin{tabular}{|c|c|c|c|c|c|c|}
\hline \multirow{3}{*}{$\begin{array}{l}\text { Número de } \\
\text { questões } \\
\text { corretas }\end{array}$} & \multicolumn{6}{|c|}{ Conhecimento sobre custos } \\
\hline & \multicolumn{2}{|c|}{$\begin{array}{c}\text { Conceitos de } \\
\text { custos }\end{array}$} & \multicolumn{2}{|c|}{$\begin{array}{c}\text { Classificação } \\
\text { dos custos }\end{array}$} & \multicolumn{2}{|c|}{$\begin{array}{c}\text { Departamentalização } \\
\text { de custos }\end{array}$} \\
\hline & $\mathbf{N}$ & $\%$ & $\mathbf{N}$ & $\%$ & $\mathbf{N}$ & $\%$ \\
\hline 0 & 35 & 18,7 & 47 & 25,1 & 51 & 27,3 \\
\hline 1 & 37 & 19,8 & 29 & 15,5 & 66 & 35,3 \\
\hline 2 & 49 & 26,2 & 39 & 20,9 & 47 & 25,1 \\
\hline 3 & 55 & 29,4 & 21 & 11,2 & 14 & 7,5 \\
\hline 4 & 11 & 5,9 & 51 & 27,3 & 9 & 4,8 \\
\hline
\end{tabular}

No primeiro agrupamento, das questões 19 a 24, não houve enfermeira com mais de quatro acertos, dentre os possíveis seis acertos. Foi considerado conhecimento mínimo a enfermeira que acertou pelo menos metade das questões, ou seja, pelo menos três questões.

Para os demais agrupamentos que possuem quatro questões, foi definido pela pesquisadora como conhecimento mínimo sobre o assunto quando o sujeito acerta duas ou mais respostas.

Tabela 23 - Freqüências absolutas e relativas do conhecimento mínimo em cada agrupamento, São Paulo - 2011

Sobre os Custos

\begin{tabular}{|c|c|c|c|c|c|c|c|c|}
\hline \multirow[b]{2}{*}{ Conhecimento } & \multicolumn{2}{|c|}{ Conceitos } & \multicolumn{2}{|c|}{ Classificação } & \multicolumn{2}{|c|}{ Departamentalização } & \multicolumn{2}{|c|}{ Apropriação } \\
\hline & $\mathbf{N}$ & $\%$ & $\mathrm{~N}$ & $\%$ & $\mathbf{N}$ & $\%$ & $\mathbf{N}$ & $\%$ \\
\hline Não & 121 & 64,7 & 76 & 40,6 & 117 & 62,6 & 117 & 62,6 \\
\hline Sim & 66 & 35,3 & 111 & 59,4 & 70 & 37,4 & 70 & 37,4 \\
\hline
\end{tabular}

Após a apuração dos dados visualizados nas tabelas 21, 22 e 23, em relação aos conhecimentos podemos verificar os seguintes resultados:

- Em relação ao conhecimento geral sobre custos, 76 (40,6\%) enfermeiras acertaram mais da metade das questões;

- Em relação ao conhecimento sobre conceitos de custos, 66 $(35,3 \%)$ enfermeiras acertaram mais da metade das questões; 
- Em relação ao conhecimento sobre a classificação dos custos, $111(59,4 \%)$ enfermeiras acertaram mais da metade das questões;

- Em relação ao conhecimento sobre departamentalização de custos, $70(37,4 \%)$ enfermeiras acertaram mais da metade das questões;

- Em relação ao conhecimento sobre metodologia de apropriação de custos, $70(37,4 \%)$ enfermeiras acertaram mais da metade das questões.

Com os achados nos dados apresentados acima, identificamos que somente no que se refere ao conhecimento sobre classificações dos custos, mais da metade da amostra deste estudo foi considerada como possuidora de conhecimento mínimo do assunto. Já nas avaliações sobre o conhecimento dos conceitos, departamentalização e metodologia de apuração de custos, conhecimentos estes mais específicos, envolvendo os centros de custos, centros de produção e o método de apuração dos custos, podem considerar que somente $66(35,3 \%), 70(37,4 \%)$ e $70(37,4 \%)$ enfermeiras respectivamente têm conhecimento mínimo.

Estudo realizado com gestores de enfermagem sobre conceitos de custos hospitalares investigando um elenco de 20 questões mostrou que $53,3 \%$ das enfermeiras possuíam conhecimento geral sobre custos, índice superior ao encontrado nesta pesquisa. O estudo ainda mostrou que $40 \%$ das enfermeiras apresentaram conhecimentos sobre custos, $60 \% \mathrm{em}$ relação à classificação de custos, 33\% em relação à departamentalização e $46 \%$ em relação ao método de apuração de custos. Estes autores concluíram que embora trabalhando em hospitais com metodologia implantada para apropriação de custos, a maioria dos gestores apresentou conhecimento baixo e foi considerado pelas autoras o conhecimento mínimo de $80 \%$ de acertos ${ }^{(15)}$.

Dallora ${ }^{(37)}$ apontou em seu estudo que os gerentes dos centros de custos de um Hospital de Ensino possuíam baixo conhecimento no que se refere aos conceitos elementares sobre custos.

Outros autores afirmam que o profissional de enfermagem envolvido no processo gerencial das instituições de saúde necessita buscar 
conhecimentos sobre custos hospitalares para alcançar resultados positivos entre quantidade, qualidade e custos ${ }^{(12)}$.

Os valores encontrados nesta pesquisa foram considerados inferiores ao esperado e à literatura, pois, as enfermeiras precisam estar capacitadas para identificarem e analisarem criticamente os custos do setor para atenderem às exigências de um mercado competitivo onde reduzir custos é um dos pontos principais, e também para atenderem aos objetivos institucionais.

Para avaliar uma possível associação entre as variáveis, testar a homogeneidade entre as proporções especialização e conhecimento sobre custos, mensurado através do número de acertos nas questões 19 a 33, foi realizado o teste qui-quadrado ${ }^{* *}$ ou o teste exato de Fisher ${ }^{* *}$.

Tabela 24 - Freqüências absolutas e relativas do conhecimento geral sobre custos das 76 enfermeiras segundo os grupos de especialização, São Paulo - 2011

\begin{tabular}{cccc}
\hline Especialização & $\mathbf{N}$ & $\%$ & $\mathbf{p}^{*}$ \\
\hline Adm. Hosp. & 16 & 80,0 & \\
Esp Básica & 21 & 26,9 & $<0,001$ \\
Outras & 32 & 45,7 & \\
Sem Esp. & 7 & 36,8 & \\
\hline${ }^{* *}$ nível descritivo de probabilidade do teste qui-quadrado
\end{tabular}

Ao analisar a tabela 24 , os dados mostram que os grupos de especialização apresentam diferença significativa em relação ao conhecimento geral sobre custos. O grupo de Administração Hospitalar apresenta maior percentual de casos com acerto, $80 \%$, do que os demais grupos $(p<0,001)$. Os demais grupos não diferem entre si $(p=0,067)$.

Entende-se que ao procurar aprimoramento profissional em um curso de especialização em administração hospitalar, a enfermeira tende a incrementar seu conhecimento sobre conceitos de custos e gestão de custos e isso favorece o desempenho em seu ambiente de trabalho.

${ }^{* *}$ Rosner B. Fundamentals of Biostatistics. Boston: PWS Publishers; 1986. 
Tabela 25 - Freqüências absolutas e relativas do conhecimento geral sobre custos das 76 enfermeiras segundo os cargos ocupados, São Paulo - 2011

\begin{tabular}{cccc}
\hline Cargos & N & $\%$ & $\mathbf{P}^{*}$ \\
\hline Enf. Junior & 7 & 26,9 & \\
Enf. Pleno & 53 & 38,4 & \\
Enf. Sênior & 11 & 61,1 & 0,009 \\
Auditor & 3 & 100,0 & \\
Coordenador & 2 & 100,0 & \\
\hline
\end{tabular}

$\left(^{*}\right)$ nível descritivo de probabilidade do teste exato de Fisher

A tabela 25 mostra que há diferença significativa em relação ao conhecimento geral sobre custos de acordo com o cargo ocupado na instituição.

Os dois cargos com maiores percentuais de acerto foram auditor e coordenador, $100 \%$ em cada uma delas, ou seja, das 76 enfermeiras que foram consideradas como tendo conhecimento mínimo sobre conceitos de custos, todas as auditoras e coordenadoras acertaram pelo menos metade das questões.

Pode-se visualizar na tabela 2 que no estudo houve somente três enfermeiras auditoras e duas coordenadoras, o que sugere que por sua formação específica e função desempenhada na instituição, ambas estão mais preparadas para desenvolver o gerenciamento de custos. Destas cinco enfermeiras, uma das auditoras e uma coordenadora possuem especialização em administração hospitalar.

Os casos de acerto dos demais grupos foram inferiores, em ordem decrescente podemos visualizar $11(61,1 \%)$ enfermeiras Sênior, 53 (38,4\%) enfermeiras Pleno e sete (26,9\%) enfermeiras Junior.

Estes dados mostram que de acordo com a função que a enfermeira desenvolve, está mais apta para gerenciar custos do que outras. Foi explicada anteriormente a diferença entre as categorias de enfermeiras das instituições e as enfermeiras Sênior são enfermeiras mais antigas na instituição e com mais tempo de formação. Infere-se que estas tenham tido mais oportunidade de aprimoramento sobre custos uma vez que a instituição as exige tal conhecimento, pois atuam tanto na área assistencial quanto na administrativa. Assim, pode-se afirmar que, a prática profissional, e não os 
cursos de aprimoramento trazem capacitação às enfermeiras que atuam na área gerencial.

Tabela 26 - Valores descritivos da idade e dos tempos, segundo o grupo de acerto, São Paulo - 2011

\begin{tabular}{llccccccc}
\hline Variável & Acerto & $\mathbf{N}$ & Média & DP & Mediana & Mínimo & Máximo & $\mathbf{p}$ \\
\hline Idade & Não & 109 & 32,79 & 6,69 & 31 & 22 & 53 & $0,748^{(1)}$ \\
& Sim & 75 & 33,11 & 6,39 & 33 & 21 & 50 & \\
$\begin{array}{l}\text { Tempo de } \\
\text { formado }\end{array}$ & Não & 106 & 6,93 & 5,44 & 6 & 1 & 30 & $0,004^{(2)}$ \\
& Sim & 71 & 9,32 & 6,11 & 8 & 1 & 25 & \\
Tempo na & & & & & & & & \\
instituição & Não & 103 & 6,26 & 4,92 & 5 & 1 & 30 & $0,984^{(2)}$ \\
& Sim & 75 & 6,31 & 4,89 & 6 & 1 & 22 & \\
& & & & & & & & \\
Tempo no cargo & Não & 100 & 5,66 & 4,86 & 4 & 1 & 30 & $0,333^{(2)}$ \\
& Sim & 66 & 6,02 & 4,27 & 5 & 1 & 20 & \\
\hline
\end{tabular}

(1) nível descritivo de probabilidade do teste t de Student

(2) nível descritivo de probabilidade do teste não-paramétrico de Mann-Whitney

A análise da tabela 26 mostrou que os grupos de acerto diferem em relação ao tempo de formado $(p=0,004)$. O grupo com acerto apresenta tempo de formado significativamente maior do que o do grupo sem acerto.

Foi realizado o teste não-paramétrico de Mann-Whitney e o resultado mostrou que os grupos de acerto não diferem em relação à idade, tempo na instituição e tempo no cargo ( $p>0,005)$.

Tabela 27 - Freqüências absolutas e relativas do conhecimento geral sobre custos das 76 enfermeiras segundo os grupos de especialização, São Paulo - 2011

\begin{tabular}{|c|c|c|c|c|c|c|c|c|c|}
\hline \multirow{3}{*}{$\begin{array}{c}\text { Conhecimento } \\
\text { Sobre }\end{array}$} & \multicolumn{8}{|c|}{ Especialização } & \multirow[b]{3}{*}{$\mathbf{p}^{*}$} \\
\hline & \multicolumn{2}{|c|}{$\begin{array}{l}\text { Adm. } \\
\text { Hosp. }\end{array}$} & \multicolumn{2}{|c|}{$\begin{array}{l}\text { Esp. } \\
\text { Básica }\end{array}$} & \multicolumn{2}{|c|}{ Outras } & \multicolumn{2}{|c|}{$\begin{array}{l}\text { Sem } \\
\text { esp. }\end{array}$} & \\
\hline & $\mathbf{N}$ & $\%$ & $\mathbf{N}$ & $\%$ & $\mathbf{N}$ & $\%$ & $\mathbf{N}$ & $\%$ & \\
\hline Conceitos & 8 & 40,0 & 21 & 26,9 & 28 & 40,0 & 9 & 47,4 & 0,214 \\
\hline Classificação & 16 & 80,0 & 38 & 48,7 & 45 & 64,3 & 12 & 63,2 & 0,046 \\
\hline Departamentalização & 14 & 70,0 & 18 & 23,1 & 31 & 44,3 & 7 & 36,8 & $\begin{array}{c}< \\
0,001\end{array}$ \\
\hline Apropriação & 5 & 35,0 & 32 & 41,0 & 28 & 40,0 & 5 & 26,3 & 0,399 \\
\hline
\end{tabular}


Podemos observar pela tabela acima que os quatro grupos de especialização não diferem em relação aos conhecimentos sobre conceitos de custos $(p=0,214)$.

Observa-se também, pela tabela acima, que os quatro grupos de especialização diferem em relação ao conhecimento sobre a classificação dos custos $(p=0,046)$. O grupo com Administração Hospitalar apresenta maior percentual de casos com acerto, 16 enfermeiras (80\%), superior aos demais grupos ( $p=0,047)$. Os grupos Especialização Básica, Outras e Sem Especialização não apresentam diferença significativa entre si $(p=0,132)$.

Os quatro grupos de especialização diferem em relação à departamentalização dos custos $(p<0,001)$. O grupo de Administração Hospitalar apresenta maior percentual de casos com acerto, 14 (70\%) enfermeiras, do que os demais grupos $(p<0,001)$. Os grupos Especialização Básica e Sem Especialização não apresentam diferença significativa entre si $(p=0,266)$. O grupo Outras difere significativamente destes dois grupos $(p=0,036)$.

No que se refere à apropriação dos custos, podemos observar que os quatro grupos de especialização não diferem entre si $(p=0,399)$.

Tabela 28 - Freqüências absolutas e relativas do conhecimento geral sobre custos das 76 enfermeiras segundo os grupos de funções desenvolvidas, São Paulo - 2011

\begin{tabular}{|c|c|c|c|c|c|c|}
\hline \multirow[b]{2}{*}{ Conhecimento } & \multicolumn{5}{|c|}{ Cargos } & \multirow[b]{2}{*}{$p^{*}$} \\
\hline & $\begin{array}{c}\text { Enf. } \\
\text { Junior } \\
\mathbf{N}(\%)\end{array}$ & $\begin{array}{c}\text { Enf. } \\
\text { Pleno } \\
\text { N (\%) }\end{array}$ & $\begin{array}{c}\text { Enf. } \\
\text { Sênior } \\
\mathbf{N}(\%)\end{array}$ & $\begin{array}{c}\text { Auditor } \\
\mathbf{N}(\%)\end{array}$ & $\frac{\text { Coordenador }}{\text { N (\%) }}$ & \\
\hline Conceitos & $\begin{array}{c}10 \\
(38,5 \%)\end{array}$ & $\begin{array}{c}47 \\
(34,1 \%)\end{array}$ & $\begin{array}{c}7 \\
(38,9 \%)\end{array}$ & $\begin{array}{c}1 \\
(33,3 \%)\end{array}$ & $1(50,0 \%)$ & 0,947 \\
\hline Classificação & $\begin{array}{c}14 \\
(53,9 \%)\end{array}$ & $\begin{array}{c}79 \\
(57,3 \%)\end{array}$ & $\begin{array}{c}13 \\
(72,2 \%)\end{array}$ & $\begin{array}{c}3 \\
(100,0 \%)\end{array}$ & $2(100,0 \%)$ & 0,338 \\
\hline Departamentalização & $\begin{array}{c}10 \\
(38,5 \%)\end{array}$ & $\begin{array}{c}43 \\
(31,2 \%)\end{array}$ & $\begin{array}{c}13 \\
(72,2 \%)\end{array}$ & $\begin{array}{c}2 \\
(66,7 \%)\end{array}$ & $2(100,0 \%)$ & 0,001 \\
\hline Apropriação & $\begin{array}{c}7 \\
(26,9 \%)\end{array}$ & $\begin{array}{c}53 \\
(38,4 \%)\end{array}$ & $\begin{array}{c}8 \\
(44,4 \%)\end{array}$ & $\begin{array}{c}1 \\
(33,3 \%)\end{array}$ & $1(50,0 \%)$ & 0,736 \\
\hline
\end{tabular}

$\left(^{*}\right)$ nível descritivo de probabilidade do teste exato de Fisher

Podemos observar pela tabela acima que os grupos de cargos não diferem em relação aos conhecimentos sobre conceitos, classificação e apropriação de custos. Porém, os grupos diferem em relação à 
departamentalização. Os cargos de enfermeira Sênior, enfermeira Auditora e Coordenador apresentam percentual de acerto maior que as funções enfermeira Pleno e Junior, respectivamente $13(72,2 \%)$, duas $(66,7 \%)$ e duas $(100 \%)$ enfermeiras.

A tabela 29 apresenta a comparação dos grupos de acerto sobre conhecimentos de custos em relação à idade, tempo de formado, tempo no cargo e tempo na instituição.

Tabela 29 - Valores descritivos da idade e dos tempos de formado, na instituição e no cargo no agrupamentos de conhecimentos sobre custos, São Paulo - 2011

\begin{tabular}{|c|c|c|c|c|c|c|c|c|}
\hline Variável & Acerto & $\mathbf{N}$ & Média & DP & Mediana & Mínimo & Máximo & $\mathbf{P}$ \\
\hline \multicolumn{9}{|l|}{$\begin{array}{l}\text { Conhecimento sobre } \\
\text { Conceitos }\end{array}$} \\
\hline \multirow[t]{2}{*}{ Idade } & Não & 119 & 32,64 & 6,40 & 31 & 21 & 50 & $0,435^{(1)}$ \\
\hline & Sim & 65 & 33,43 & 6,85 & 33 & 22 & 53 & \\
\hline \multirow[t]{2}{*}{ Tempo de formado } & Não & 115 & 7,50 & 5,59 & 6 & 1 & 30 & $0,285^{(2)}$ \\
\hline & Sim & 62 & 8,62 & 6,21 & 7 & 1 & 25 & \\
\hline \multirow[t]{2}{*}{ Tempo na instituição } & Não & 115 & 6,31 & 4,94 & 5 & 1 & 30 & $0,805^{(2)}$ \\
\hline & Sim & 63 & 6,22 & 4,85 & 5 & 1 & 22 & \\
\hline \multirow[t]{2}{*}{ Tempo no cargo } & Não & 108 & 5,72 & 4,92 & 4 & 1 & 30 & $0,292^{(2)}$ \\
\hline & Sim & 58 & 5,95 & 4,06 & 5 & 1 & 20 & \\
\hline \multicolumn{9}{|l|}{$\begin{array}{l}\text { Conhecimento sobre } \\
\text { Classificação }\end{array}$} \\
\hline \multirow[t]{2}{*}{ Idade } & Não & 74 & 32,22 & 6,37 & 30 & 22 & 50 & $0,234^{(1)}$ \\
\hline & Sim & 110 & 33,39 & 6,66 & 33 & 21 & 53 & \\
\hline \multirow[t]{2}{*}{ Tempo de formado } & Não & 72 & 6,89 & 5,30 & 6 & 1 & 30 & $0,064^{(2)}$ \\
\hline & Sim & 105 & 8,58 & 6,08 & 7 & 1 & 25 & \\
\hline \multirow[t]{2}{*}{ Tempo na instituição } & Não & 70 & 6,06 & 4,92 & 5 & 1 & 30 & $0,584^{(2)}$ \\
\hline & Sim & 108 & 6,43 & 4,90 & 6 & 1 & 25 & \\
\hline \multirow[t]{2}{*}{ Tempo no cargo } & Não & 68 & 5,91 & 4,82 & 4 & 1 & 30 & $0,831^{(2)}$ \\
\hline & Sim & 98 & 5,72 & 4,51 & 5 & 1 & 25 & \\
\hline \multicolumn{9}{|c|}{$\begin{array}{l}\text { Conhecimento sobre } \\
\text { Departamentalização }\end{array}$} \\
\hline \multirow[t]{2}{*}{ Idade } & Não & 116 & 33,04 & 6,84 & 31 & 22 & 53 & $0,737^{(1)}$ \\
\hline & Sim & 68 & 32,71 & 6,08 & 31 & 21 & 49 & \\
\hline \multirow[t]{2}{*}{ Tempo de formado } & Não & 115 & 6,87 & 5,54 & 5 & 1 & 30 & $<0,001^{(2)}$ \\
\hline & Sim & 62 & 9,79 & 5,88 & 8 & 1 & 25 & \\
\hline
\end{tabular}


Tabela 29 - Valores descritivos da idade e dos tempos de formado, na instituição e no cargo sobre os agrupamentos de conhecimentos sobre custos, São Paulo - 2011

Continuação

\begin{tabular}{lcccccccc} 
Tempo na instituição Não & 113 & 6,00 & 5,01 & 4 & 1 & 30 & $0,152^{(2)}$ \\
& Sim & 65 & 6,77 & 4,68 & 6 & 1 & 20 & \\
Tempo no cargo & & & & & & & & \\
& Não & 107 & 5,54 & 4,77 & 4 & 1 & 30 & $0,124^{(2)}$ \\
& Sim & 59 & 6,27 & 4,34 & 5 & 1 & 20 & \\
\hline Apropriação & & & & & & & & \\
\hline Idade & Não & 114 & 33,00 & 6,30 & 32,50 & 21 & 53 & $0,830(1)$ \\
& Sim & 70 & 32,79 & 6,99 & 30,00 & 22 & 50 & \\
Tempo de formado & Não & 111 & 7,20 & 5,53 & 6 & 1 & 25 & $0,023(2)$ \\
& Sim & 66 & 9,06 & 6,15 & 7 & 2 & 30 & \\
Tempo na instituição & Não & 111 & 5,67 & 4,15 & 5 & 1 & 22 & $0,076(2)$ \\
& Sim & 67 & 7,30 & 5,82 & 6 & 1 & 30 & \\
Tempo no cargo & Não & 105 & 4,99 & 3,69 & 4 & 1 & 15 & $0,006(2)$ \\
& Sim & 61 & 7,20 & 5,67 & 6 & 1 & 30 & \\
\hline
\end{tabular}

(1) nível descritivo de probabilidade do teste t de Student

(2) nível descritivo de probabilidade do teste não-paramétrico de Mann-Whitney

Podemos observar pela tabela 29 que o grupo de acerto (as 76 enfermeiras) com relação ao conhecimento sobre conceitos e classificação de custos não difere em relação à idade, tempo de formado, tempo na instituição e tempo no cargo ( $p>0,005)$.

No item departamentalização, percebe-se que o grupo de acerto difere em relação ao tempo de formado, significativamente maior do que o do grupo sem acerto. Este grupo de acerto, ainda em departamentalização, não difere em relação à idade, tempo na instituição e tempo no cargo.

Por atuarem a mais tempo como enfermeiras, e por terem experiência na atividade desenvolvida de acordo com as padronizações das instituições de saúde, foi possível demonstrar que quanto maior o tempo de formado, maior a chance de acertar conceitos sobre departamentalização.

Ainda na análise desta tabela, no item apropriação, observa-se que o grupo de acerto difere em relação ao tempo de formado e no cargo. O grupo com acerto na apuração apresenta tempo de formado e tempo no cargo significativamente maior do que o do grupo sem acerto. E não diferem em relação à idade e tempo na instituição. 


\subsection{A PARTICIPAÇÃO DAS ENFERMEIRAS NO GERENCIAMENTO DE CUSTOS}

Nas tabelas a seguir apresentamos as repostas obtidas relativas à parte IV do instrumento referente às condições institucionais para a realização do gerenciamento de custos.

34) Você se sente preparado (a) para gerenciar custos hospitalares?

35) Você encontra dificuldades no gerenciamento de custos?

Tabela 30 - Distribuição de freqüências das 187 enfermeiras, segundo as respostas das questões 34 e 35, São Paulo - 2011

\begin{tabular}{lccc}
\hline Questão & Resposta & N & $\%$ \\
\hline \multirow{3}{*}{34} & Sim & 24 & 12,8 \\
& Não & 161 & 86,1 \\
& Sem resposta & 2 & 1,1 \\
& & & \\
35 & Sim & 140 & 74,9 \\
& Não & 41 & 21,9 \\
& Sem resposta & 6 & 3,2 \\
\hline
\end{tabular}

Na questão 34, $161(86,1 \%)$ enfermeiras responderam não, que não se sentem preparadas para gerenciar custos hospitalares e somente 24 $(12,8 \%)$ possuem tal sentimento. Não houve justificativa para esta questão.

A questão 35 abordou se a enfermeira sente dificuldades no gerenciamento de custos e 41 (21,9\%) enfermeiras responderam não, sem justificativa.

Outras $140(74,9 \%)$ enfermeiras responderam que encontram dificuldades para gerenciar os custos.

Estudo realizado com enfermeiras no estado de Minas Gerais mostrou que na maioria dos casos os profissionais apresentam dificuldades ao se relacionarem com a questão contábil. Sugere-se ainda neste estudo, mudanças na formação acadêmica onde muitas enfermeiras confessam que foram buscar especializações na área para atender às necessidades da instituição e do mercado ${ }^{(56)}$. 
Ainda nesta questão houve um espaço para a justificativa, que por ser aberta, possibilitou às enfermeiras responderem com mais de um argumento. As justificativas foram agrupadas em categorias e apresentadas a seguir.

Tabela 31 - Distribuição de freqüências das 181 justificativas para resposta afirmativa na questão 35, São Paulo - 2011

\begin{tabular}{llrr}
\hline & & \multicolumn{2}{c}{ SIM } \\
\hline Justificativa & & \multicolumn{1}{c}{ N } & \multicolumn{1}{c}{$\%$} \\
\hline Não justificado & INST A & 105 & $58 \%$ \\
& INST B & 0 & $0 \%$ \\
Falta & & & \\
conhecimento & INST A & 62 & $34 \%$ \\
& INST B & 3 & $2 \%$ \\
Falta & & & \\
acesso/inform & INST A & 4 & $2 \%$ \\
& INST B & 3 & $2 \%$ \\
planilhas/cálculo & INST A & 1 & $1 \%$ \\
& INST B & 3 & $2 \%$ \\
\hline
\end{tabular}

A Tabela 31 mostra que das 140 enfermeiras com respostas afirmativas, 65 (36\%) justificativas relacionaram-se à falta de conhecimento sobre o assunto para desempenhar tal atividade. Outras sete (4\%) respostas foram atribuídas à falta de acesso às informações e quatro $(3 \%)$ respostas colocam que as enfermeiras não compreendem planilhas e cálculos de custos para desempenhar com êxito a atividade.

Autores apontam uma deficiência na formação da enfermeira para lidar com custos na área da saúde, e como conseqüência esta profissional sente-se despreparada para atuar com segurança no gerenciamento de custos $^{(6)}$.

Outros autores complementam que é preciso ensinar conteúdos específicos sobre o tema custos na graduação já que este tema foi inserido desde o primeiro currículo de enfermagem, em $1890^{(12)}$.

36) De acordo com sua experiência profissional, você identifica vantagens no gerenciamento de custos?

Nesta questão, 134 (71,65\%) enfermeiras responderam que identificam vantagens no gerenciamento de custos, $47 \quad(25,15 \%)$ 
responderam que não e outras seis $(3,2 \%)$ não responderam, de acordo com a Figura 18.

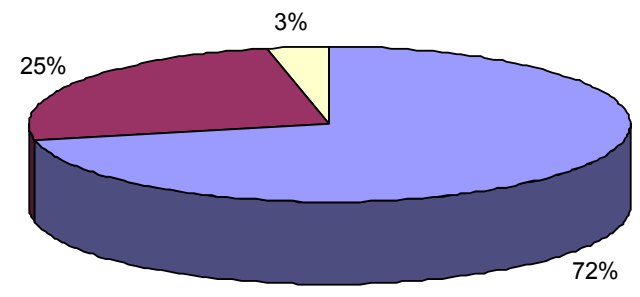

Figura 18 - Percentual de enfermeiras que identificam vantagens no gerenciamento de custos, São Paulo - 2011

Como a questão foi aberta, possibilitou às enfermeiras responderem mais de uma justificativa e com isso as respostas foram categorizadas para melhor compreensão e apresentação dos dados. Obteve-se o total de 144 respostas afirmativas das 134 enfermeiras, apresentadas na Tabela 27.

Tabela 32 - Distribuição de freqüências das 144 justificativas das enfermeiras com resposta afirmativa na questão 36, São Paulo - 2011

\begin{tabular}{lrrr}
\hline & & \multicolumn{2}{c}{ SIM } \\
\hline Justificativa & & \multicolumn{1}{c}{ N } & \multicolumn{1}{c}{$\%$} \\
\hline não justificado & INST A & 73 & $51 \%$ \\
& INST B & 4 & $3 \%$ \\
Identificar & & & \\
desperdícios & INST A & 21 & $15 \%$ \\
& INST B & 7 & $5 \%$ \\
qualidade de & & & \\
produtos & INST A & 3 & $2 \%$ \\
& INST B & 3 & $2 \%$ \\
Custom de & & & \\
materiais & INST A & 12 & $8 \%$ \\
& INST B & 3 & $2 \%$ \\
Investimento & INST A & 15 & $10 \%$ \\
& INST B & 3 & $2 \%$ \\
\hline
\end{tabular}

Dentre as enfermeiras, $28(20 \%)$ respostas foram que identificar desperdícios é uma das vantagens, seguida por 18 (12\%) respostas sobre possibilitar investimentos, 15 (10\%) sobre avaliar custo de materiais, seis (4\%) sobre a possibilidade de avaliar a qualidade de produtos. Ainda temos 
77 (54\%) enfermeiras que identificam vantagens, mas não justificaram suas respostas.

Resultados de estudos mostram que a enfermeira, ao se tratar do assunto custos, associa-o diretamente à aquisição de materiais e equipamentos nas instituições de saúde. Não que o assunto não esteja relacionado, mas o gerenciamento de custos engloba muito mais do que recursos materiais ${ }^{(56)}$.

Diante disso, os achados neste estudo vão de encontro aos de estudos anteriores dos quais ao se questionar as enfermeiras sobre as vantagens de gerenciar custos, 61 (42\%) das justificativas estão relacionadas ao gerenciamento de materiais como avaliação do desperdício, investimentos em novas tecnologias e avaliação dos custos dos materiais e da qualidade dos produtos.

37) Você acredita que o gerenciamento de custos é uma atribuição do enfermeira? Por que?

Nesta questão, 148 (79,15\%) enfermeiras responderam que acreditam que o gerenciamento de custos é uma atribuição da enfermeira. $E$ $39(20,85 \%)$ enfermeiras, sendo 35 da Instituição A e quatro da Instituição B apresentaram resposta negativa nesta questão.

A questão foi aberta e possibilitou às enfermeiras justificarem com mais de um argumento.

Destas 39 enfermeiras que responderam não à questão, dez justificaram que a enfermeira tem muitas atribuições e que mais uma atividade não seria possível realizar, que esta deve ser direcionada aos administradores hospitalares. As demais não justificaram.

As 158 justificativas das 148 enfermeiras que responderam sim nesta questão foram categorizadas e apresentadas na tabela 33. 
Tabela 33 - Distribuição de freqüências das 158 justificativas das enfermeiras com resposta afirmativa na questão 37 , São Paulo - 2011

\begin{tabular}{llrr} 
Justificativa & & \multicolumn{2}{c}{ SIM } \\
\hline relação & & N & \\
custo/benefício & INST A & 1 & $1 \%$ \\
& INST B & 1 & $1 \%$ \\
qualidade produtos & INST A & 0 & $0 \%$ \\
& INST B & 2 & $1 \%$ \\
identificar & & & \\
desperdício & INST A & 1 & $1 \%$ \\
& INST B & 1 & $1 \%$ \\
profissional mais & & & \\
preparado & INST A & 85 & $57 \%$ \\
& INST B & 7 & $5 \%$ \\
não justificou & INST A & 60 & $41 \%$ \\
& INST B & 0 & $0 \%$ \\
\hline
\end{tabular}

O maior percentual encontrado foi a categoria profissional mais preparado com 85 (57\%) respostas na Instituição A e sete (5\%) na Instituição B. As enfermeiras explicaram que apesar de acreditarem que o gerenciamento de custos é uma atribuição delas, precisam ser capacitadas e se sentirem mais preparadas para atuar com segurança no desempenho gerencial de custos.

Somente duas enfermeiras (1\%) justificaram em suas respostas que se sentem preparadas quando o assunto é relação custo/benefício.

Este estudo proporcionou também uma análise comparativa entre as enfermeiras das instituições de saúde selecionadas.

\subsection{COMPARAÇÕES ENTRE AS INSTITUIÇÕES}

Serão apresentados abaixo gráficos e tabelas para maior compreensão destes dados comparativos.

Os gráficos e tabelas abaixo apresentam as características da idade e gênero das instituições. 


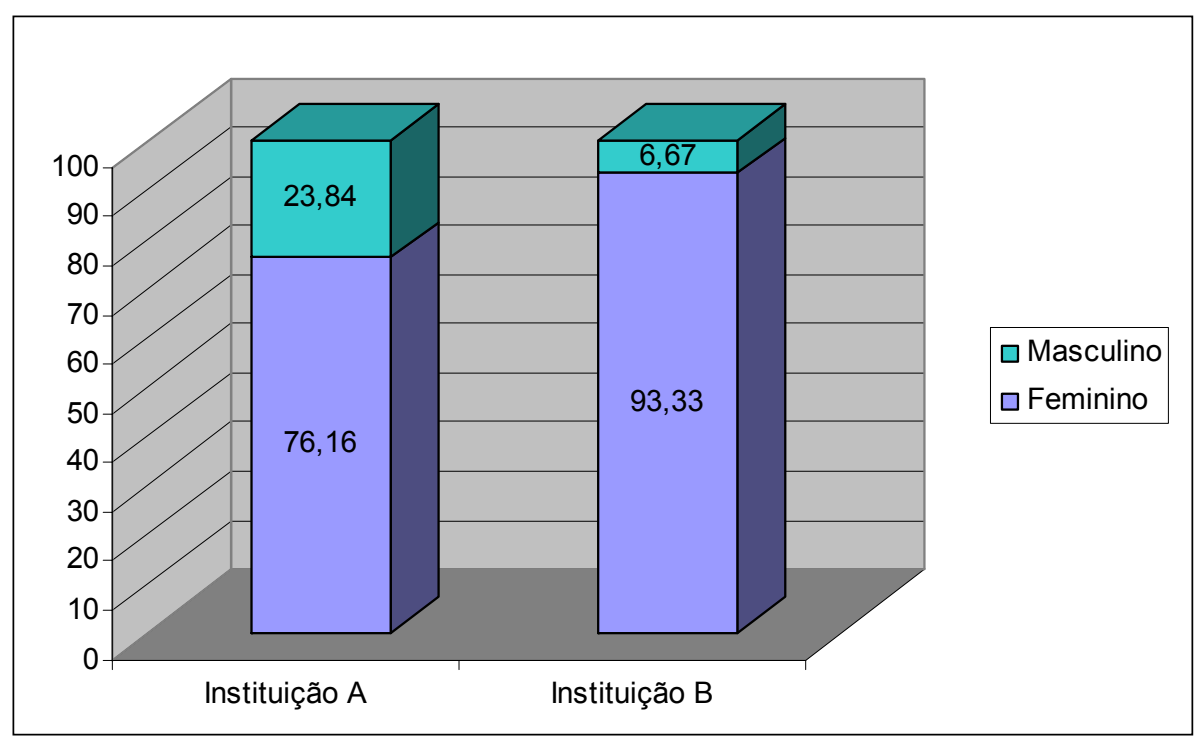

Figura 19 - Características quanto ao gênero das enfermeiras das instituições do estudo, São Paulo - 2011

Os dados da figura 19 mostram que houve predominância do sexo feminino nas duas instituições A e B com respectivamente $76,16 \%$ e $93,33 \%$.

Tabela 34 - Valores descritivos da idade e gênero, segundo a instituição de estudo, São Paulo - 2011

\begin{tabular}{|c|c|c|c|c|}
\hline \multirow[b]{2}{*}{ Variável } & & \multicolumn{2}{|c|}{ Instituição } & \multirow[b]{2}{*}{ p } \\
\hline & & A & B & \\
\hline Idade & Média \pm DP & $32,86 \pm 6,65$ & $33,57 \pm 5,45$ & $0,699^{(1)}$ \\
\hline \multirow[t]{2}{*}{ Gênero } & Feminino & $131(76,2 \%)$ & $14(93,3 \%)$ & $0,197^{(2)}$ \\
\hline & Masculino & $41(23,8 \%)$ & $1(6,7 \%)$ & \\
\hline
\end{tabular}

(2) nível descritivo de probabilidade do teste exato de Fisher

Pela tabela 34 observamos que as instituições não diferem em relação à idade e sexo, ou seja, não houve significância ( $p=0,699$ e $p=0.197)$. 
Tabela 35 - Valores descritivos dos tempos de formação, de atuação na instituição e no cargo, segundo a instituição de estudo, São Paulo - 2011

\begin{tabular}{llccccccc}
\hline Tempo de & Instituição & $\mathbf{N}$ & Média & DP & Mediana & Mínimo & Máximo & * $^{*}$ \\
\hline Formação & A & 163 & 8,12 & 5,82 & 7 & 1 & 30 & 0,022 \\
& B & 14 & 5,29 & 5,28 & 4 & 1 & 23 & \\
Atuação & & & & & & & & \\
na & & & & & & & & \\
Instituição & A & 163 & 6,62 & 4,98 & 6 & 1 & 30 & $<0,001$ \\
& B & 15 & 2,60 & 0,83 & 3 & 1 & 3 & \\
Cargo & A & 152 & 6,08 & 4,72 & 5 & 1 & 30 & 0,003 \\
& B & 14 & 2,79 & 1,58 & 3 & 1 & 6 & \\
\hline
\end{tabular}

$\left(^{*}\right)$ nível descritivo de probabilidade do teste não-paramétrico de Mann-Whitney

Portanto pela tabela 35 observou-se que as instituições apresentam diferença significativa em relação aos tempos de formado, de instituição e no cargo.

$\mathrm{Na}$ instituição $\mathrm{A}$ as enfermeiras possuem uma média de tempo de formação de 8,11 (DP $\pm 5,82$ ) anos com mediana de sete anos, enquanto na instituição $B$, este tempo tem média de 5,28 (DP $\pm 5,28$ ) anos com mediana de quatro anos.

A tabela acima mostra que há diferença significativa $(p<0,001)$ com relação entre o tempo de atuação nas instituições do estudo.

$\mathrm{Na}$ instituição $\mathrm{A}$ as enfermeiras possuem uma média de tempo de atuação de 6,62 anos (DP $\pm 4,97$ ) com mediana de seis anos, enquanto na instituição $B$, este tempo tem média de 2,6 anos (DP $\pm 0,82$ ) com mediana de três anos. Isto se deve ao fato da instituição $B$ ter somente três anos de inauguração enquanto a instituição $A$ tem mais de 15 anos.

Com relação ao tempo de atuação no cargo, na instituição $A$ as enfermeiras possuem uma média de tempo de atuação de 6,07 anos $(\mathrm{DP} \pm 4,71)$ com mediana de cinco anos, enquanto na instituição $B$, este tempo tem média de 2,78 anos (DP $\pm 1,57$ ) com mediana de três anos.

Houve diferença significativa verificada pelo teste não-paramétrico de Mann-Whitney com $p=0,003$. Portanto as instituições apresentam diferença significativa em relação ao tempo de formação, tempo de instituição e de atuação no cargo. A instituição B apresenta valor de significância menor que o da instituição A. 
Tabela 36 - Freqüências absolutas e relativas do cargo, titulação e área de titulação, segundo a instituição de estudo, São Paulo - 2011

\begin{tabular}{|c|c|c|c|c|c|c|}
\hline \multirow[b]{3}{*}{ Variável } & \multirow[b]{3}{*}{ Categoria } & \multicolumn{4}{|c|}{ Instituição } & \multirow[b]{3}{*}{$\mathrm{p}^{*}$} \\
\hline & & \multicolumn{2}{|c|}{ A } & \multicolumn{2}{|c|}{ B } & \\
\hline & & $\mathbf{N}$ & $\%$ & $\mathbf{N}$ & $\%$ & \\
\hline & Enf. Júnior & 24 & 14,0 & 2 & 13,3 & \\
\hline \multirow[t]{4}{*}{ Cargo } & Enf. Pleno & 126 & 73,3 & 12 & 80,0 & 0,233 \\
\hline & Enf. Sênior & 18 & 10,5 & 0 & 0,0 & \\
\hline & Auditor & 3 & 1,7 & 0 & 0,0 & \\
\hline & Coordenador & 1 & 0,6 & 1 & 6,7 & \\
\hline
\end{tabular}

$\begin{array}{llccccc}\text { Titulação } & \text { Sem Título } & 15 & 8,7 & 4 & 26,7 & \\ & \text { Especialização } & 150 & 87,2 & 11 & 73,3 & 0,155 \\ & \text { Mestre } & 7 & 4,1 & 0 & 0,0 & \end{array}$

\begin{tabular}{lllllll} 
& Adm. Hosp. & 18 & 10,5 & 2 & 13,3 & \\
Área & Esp. Básicas & 74 & 43,0 & 4 & 26,7 & \\
de Titulação & Outras Esp. & 65 & 37,8 & 5 & 33,3 & 0,131 \\
& Sem Título & 15 & 8,7 & 4 & 26,7 & \\
\hline
\end{tabular}

$\left({ }^{*}\right)$ nível descritivo de probabilidade do teste exato de Fisher

No que se refere ao cargo ocupado, à titulação e à especialização, não há diferença significativa entre os cargos nas duas instituições ( $p=0,233$, $p=0,115$ e $p=0,131$ respectivamente). 
Tabela 37 - Freqüências absolutas e relativas das respostas das questões 8 a 18, relativas às práticas gerencias de custos, segundo a instituição de estudo, São Paulo - 2011

\begin{tabular}{|c|c|c|c|c|c|c|}
\hline \multirow[b]{3}{*}{ Questão } & \multirow[b]{3}{*}{ Resposta } & \multicolumn{4}{|c|}{ Instituição } & \multirow[b]{3}{*}{$\mathbf{p}^{*}$} \\
\hline & & \multicolumn{2}{|c|}{ A } & \multicolumn{2}{|c|}{ B } & \\
\hline & & $N$ & $\%$ & $\mathbf{N}$ & $\%$ & \\
\hline \multirow[t]{2}{*}{8} & Sim & 47 & 27,3 & 2 & 13,3 & 0,361 \\
\hline & Não & 125 & 72,7 & 13 & 86,7 & \\
\hline \multirow[t]{2}{*}{9} & Sim & 33 & 19,3 & 2 & 13,3 & 0,741 \\
\hline & Não & 138 & 80,7 & 13 & 86,7 & \\
\hline \multirow[t]{2}{*}{10} & Sim & 24 & 14,0 & 1 & 6,7 & 0,697 \\
\hline & Não & 147 & 86,0 & 14 & 93,3 & \\
\hline \multirow[t]{2}{*}{11} & Sim & 35 & 20,4 & 1 & 6,7 & 0,310 \\
\hline & Não & 137 & 79,6 & 14 & 93,3 & \\
\hline \multirow[t]{2}{*}{12} & Sim & 18 & 10,5 & 1 & 6,7 & 1,000 \\
\hline & Não & 153 & 89,5 & 14 & 93,3 & \\
\hline \multirow[t]{2}{*}{13} & Sim & 23 & 13,5 & 1 & 6,7 & 0,697 \\
\hline & Não & 148 & 86,5 & 14 & 93,3 & \\
\hline \multirow[t]{2}{*}{14} & Sim & 18 & 10,5 & 1 & 6,7 & 1,000 \\
\hline & Não & 154 & 89,5 & 14 & 93,3 & \\
\hline \multirow[t]{2}{*}{15} & Sim & 15 & 8,8 & 0 & 0,0 & 0,615 \\
\hline & Não & 156 & 91,2 & 15 & 100,0 & \\
\hline \multirow[t]{2}{*}{16} & Sim & 15 & 8,7 & 0 & 0,0 & 0,614 \\
\hline & Não & 157 & 91,3 & 15 & 100,0 & \\
\hline \multirow[t]{2}{*}{17} & Sim & 12 & 7,0 & 0 & 0,0 & 0,603 \\
\hline & Não & 159 & 93,0 & 15 & 100,0 & \\
\hline \multirow[t]{2}{*}{18} & Sim & 28 & 16,5 & 1 & 6,7 & 0,473 \\
\hline & Não & 142 & 83,5 & 14 & 93,3 & \\
\hline
\end{tabular}

$\left({ }^{*}\right)$ nível descritivo de probabilidade do teste exato de Fisher

Analisando as questões da parte II do instrumento, não houve diferença significativa entre as enfermeiras da instituição $A$ e $B$, vise tabela acima. 
Tabela 38 - Freqüências absolutas e relativas dos acertos das questões 19 a 33 relacionadas aos principais conceitos sobre custos, segundo a instituição de estudo, São Paulo - 2011

\begin{tabular}{|c|c|c|c|c|c|}
\hline \multirow[b]{3}{*}{ Assunto } & \multicolumn{4}{|c|}{ Instituição } & \multirow[b]{3}{*}{$p^{*}$} \\
\hline & \multicolumn{2}{|c|}{ Privada } & \multicolumn{2}{|c|}{ Pública } & \\
\hline & $\mathbf{N}$ & $\%$ & $\mathbf{N}$ & $\%$ & \\
\hline Total & 69 & 40,1 & 7 & 46,7 & 0,620 \\
\hline Conhecimento Geral & 58 & 33,7 & 8 & 53,3 & 0,127 \\
\hline Classificação & 98 & 57,0 & 13 & 86,7 & 0,025 \\
\hline Departamentalização & 64 & 37,2 & 6 & 40,0 & 0,830 \\
\hline Apuração & 65 & 37,8 & 5 & 33,3 & 0,732 \\
\hline
\end{tabular}

Pela análise da tabela 38 percebemos que somente na avaliação do conhecimento mínimo com relação à classificação de custos é que houve diferença significativa entre as instituições $A$ e $B(p=0,025)$. A instituição $B$ apresenta maior percentual de enfermeiras no grupo de acertos que a instituição $A$.

As instituições não apresentam diferença significante em relação aos demais assuntos. 
9 CONCLUSÕES 


\section{CONCLUSÕES}

Este estudo permitiu as seguintes conclusões com relação à caracterização das instituições:

- A idade das enfermeiras da amostra variou entre 21 e 53 anos com média de 32,92 anos ( $D P \pm 6,56$ ) e mediana de 31 anos, sendo que $145(77,5 \%)$ profissionais eram do sexo feminino;

- O tempo médio de formação destas enfermeiras variou de um a 30 anos, média de 7,89 anos, desvio-padrão de 5,82 anos e mediana de seis anos;

- O tempo médio de atuação na instituição foi de 6,28 anos ( $D P \pm 4,90)$ e mediana de cinco anos;

- O tempo de atuação no cargo variou de um a 30 anos, média de 5,80 anos, desvio-padrão de 4,63 anos e mediana de 4,50 anos;

- 138 (73,8\%) são enfermeiras Plenas, aquelas que atuam nas instituições tanto na assistência quanto na área administrativa o que sugere uma atuação mais direta em relação ao gerenciamento de custos; e 161 (86\%) possuem alguma especialização ou mestrado. Nenhuma enfermeira possui doutorado.

Com relação à análise sobre o conhecimento das práticas gerenciais, os resultados mostraram que:

- $138(73,8 \%)$ enfermeiras não conhecem os custos do setor que atuam;

- $151(81,2 \%)$ enfermeiras não conhecem o sistema de custeio utilizado na instituição;

- $161(86,6 \%)$ enfermeiras não recebem relatórios periódicos sobre os custos do setor;

- $151(80,7 \%)$ enfermeiras não participam de reuniões periódicas para discussão sobre custos;

- $167(89,8 \%)$ enfermeiras não conhecem o orçamento do serviço de enfermagem;

- $162(87,1 \%)$ enfermeiras não conhecem o orçamento do setor; 
- $168(89,8 \%)$ enfermeiras não participam da elaboração do orçamento do setor;

- $171(91,9 \%)$ enfermeiras não possuem acesso às informações necessárias para elaboração do orçamento do setor;

- 172 (92\%) enfermeiras não conhecem o faturamento do setor que atuam;

- $174(93,5 \%)$ enfermeiras não participam da elaboração dos custos dos procedimentos/pacotes;

- $156(84,3 \%)$ enfermeiras não realizam outras atividades relacionadas a custos.

Com relação à análise sobre o conhecimento das enfermeiras sobre principais conceitos de custos hospitalares, os resultados identificaram que:

- $76(40,6 \%)$ enfermeiras possuem conhecimento geral mínimo sobre custos;

- $66(35,3 \%)$ enfermeiras possuem conhecimento mínimo sobre os conceitos de custos;

- $111(59,4 \%)$ enfermeiras possuem conhecimento mínimo sobre as classificações de custos;

- $70(37,4 \%)$ enfermeiras possuem conhecimento mínimo sobre a departamentalização dos custos;

- $70(37,4 \%)$ enfermeiras possuem conhecimento mínimo sobre os métodos de apropriação de custos;

- Destas 76 enfermeiras, 16 possuem especialização em administração hospitalar representando $80 \%$ na categoria e esta variável interferiu nos acertos sobre conhecimento de custos;

- Os dois cargos ocupados com maior percentual no grupo de acertos foram auditor e coordenador e o menor percentual foi de enfermeira Junior, $7(26,9 \%)$, aquele recém formado ou recém contratado nas instituições;

- A variável tempo de formação interferiu no percentual das enfermeiras com conhecimento mínimo sobre custos; 
- As variáveis idade, tempo de atuação na instituição e tempo no cargo não interferiram no percentual das enfermeiras com conhecimento mínimo sobre custos;

- A variável tipo de especialização não interferiu no percentual das enfermeiras com conhecimento mínimo sobre conceitos de custos nem sobre apropriação de custos;

- A variável especialização em administração hospitalar interferiu no percentual das enfermeiras com conhecimento mínimo sobre classificação e departamentalização de custos, respectivamente $80 \%$ e $70 \%$;

- A variável cargo ocupado não interferiu no conhecimento mínimo sobre classificação a apropriação de custos, mas interferiu na departamentalização de custos com percentuais de acertos das categorias de 13 (72,2\%) enfermeiras Sênior, 2 (66,7\%) enfermeiras Auditoras e $2(100 \%)$ enfermeiras Coordenadoras;

- As variáveis idade, tempo de formação, tempo de atuação na instituição e tempo no cargo não interferiram no conhecimento mínimo sobre conceitos e classificação de custos;

- Conhecimento mínimo sobre departamentalização teve interferência da variável tempo de formado;

- Conhecimento mínimo sobre apropriação de custos teve interferência das variáveis tempo de formado e tempo no cargo;

Com relação à análise sobre as condições institucionais para a realização do gerenciamento de custos, os resultados encontrados foram:

- $161(86,1 \%)$ enfermeiras não se sentem preparadas para gerenciar custos;

- $140(74,9 \%)$ encontram dificuldades neste gerenciamento entre elas $65(36 \%)$ referem falta de conhecimento específico no assunto;

- $134(71,35 \%)$ encontram vantagens no gerenciamento de custos, pois possibilita identificar desperdícios, avaliar o custo dos materiais e novos investimentos, respectivamente $28(20 \%), 15(10 \%)$ e 18 $(12 \%)$; 
- $148(79,15 \% 0$ acreditam que o gerenciamento de custos é uma atribuição da enfermeira.

Este estudo proporcionou uma análise comparativa entre as instituições A e B. Os dados mostraram que:

- Houve prevalência do sexo feminino;

- Na instituição A, a média do tempo de formação foi de 8,11 anos e na instituição B esta média foi de 5,28 anos;

- O tempo médio de atuação das enfermeiras da instituição A foi de 6,62 anos enquanto na instituição B foi de 2,6 anos;

- Não há diferença significativa entre as duas instituições sobre conhecimento mínimo de custos no que se refere às variáveis cargo, titulação e grupos de especializações. Somente em relação ao conhecimento sobre as classificações de custos houve diferença significativa entre as instituições sendo que a instituição $B$ apresentou maior percentual do que a instituição $A$. 


\section{CONSIDERAÇÕES FINAIS}

Este estudo avaliou a participação das enfermeiras no gerenciamento de custos em organizações hospitalares. Possibilitou mensurar, diante de um cenário onde há uma relação direta entre o aumento dos gastos em saúde com a elevação dos custos dos serviços prestados, o conhecimento das enfermeiras sobre conceitos, classificação, departamentalização, métodos de apropriação de custos e ainda identificar o preparo destas para gerenciar custos nas instituições onde atuam.

Os resultados mostraram que poucas enfermeiras possuem conhecimento mínimo sobre custos, independente de sua especialização, tempo de formação ou experiência na organização de saúde, para utilizá-los no gerenciamento em enfermagem nas instituições que atuam. $E$ ainda, que estas não se sentem preparadas para gerenciar custos, por falta de conhecimento e acesso às informações, apesar de acreditarem ser esta uma das atividades de responsabilidade das enfermeiras.

Percebe-se que as organizações de saúde, quando implantam o gerenciamento de custos, tendem a envolver os gerentes de unidades assistenciais, além das administrativas, e algumas até os capacitam, mas às vezes não dão continuidade ao processo, não fornecendo os relatórios ou não promovendo reuniões para discussões sobre o desenvolvimento dos custos. Esse comportamento faz com que os gerentes não consolidem o novo conhecimento.

O que é mais solicitado às enfermeiras é o controle dos gastos de materiais de consumo e, por isso, elas confundem essa atividade com o gerenciamento de custos. Proposições para contenção de custos, principalmente, de materiais de consumo, é somente uma faceta da gestão de custos.

O fato é que mesmo os administradores e contabilistas hospitalares estão mais acostumados com a contabilidade de custos para fins fiscais e financeiros, e não com a contabilidade gerencial, exercida por gerentes de áreas técnicas. 
Entretanto é incontestável que se houvesse o envolvimento de todos os gerentes dessas áreas haveria um resultado financeiro maior para os hospitais.

No estudo identificou-se que mesmo nas instituições, onde as enfermeiras têm acesso aos relatórios e orçamentos também tendem a não divulgar o mesmo para a sua equipe, ou seja, há uma interrupção na linha conhecimento e análise sobre custos. É preciso que toda a equipe envolvida tenha acesso às informações e possua conhecimento suficiente para contribuir no gerenciamento de custos nas instituições de saúde.

Não são somente as gestoras hospitalares que encontram dificuldades em gerenciar custos, o estudo mostrou que as enfermeiras precisam procurar aprimoramento específico para sua capacitação e para que possam desenvolver atividades relacionadas a custos nas instituições de saúde com segurança.

Muitas enfermeiras não se sentem preparadas e/ou não estão capacitadas para desenvolver atividades relacionadas a custos. Tal fato decorre da necessidade de buscar conhecimentos com relação aos conceitos e classificação de custos, métodos de custeio e orçamentos.

Em relação ao ensino, o tema custos está sendo inserido nos currículos dos cursos de graduação em enfermagem, nas disciplinas relacionadas à administração em enfermagem. Porém, os docentes que ministram estas disciplinas relacionadas ao gerenciamento em enfermagem, possuem conhecimento restrito sobre o tema. É preciso capacitar os docentes no assunto para que estes disseminem conhecimento aos alunos que futuramente serão enfermeiras e estarão atuando em um mercado de trabalho cada vez mais exigente quanto ao gerenciamento de custos.

Para isso, é importante e relevante definir as competências e habilidades necessárias às enfermeiras para que estas desenvolvam o gerenciamento de custos em enfermagem e em saúde.

Assim, o desenvolvimento desse estudo, apesar de suas limitações, demonstrou a necessidade de realização de outros estudos para ampliação do conhecimento e da análise dos fatores que contribuem para a 
participação efetiva das enfermeiras no gerenciamento de custos em organizações de saúde. 
REFERÊNCIAS 


\section{REFERÊNCIAS}

1. International Council of Nurses. La Calidad, los custos y la enfermería. Ginebra; 1993.

2. Cohn A, Elias PE. Saúde no Brasil: políticas e organização de serviços. São Paulo: Cortez; 1996.

3. Marquis $B L$, Huston CJ. Administração e liderança em enfermagem: teoria e aplicação. Porto Alegre: Artmed; 2010.

4. Nimitz MA. O ensino da disciplina de administração em enfermagem nas escolas de graduação da grande São Paulo [dissertação]. São Paulo: Escola de Enfermagem, Universidade de São Paulo; 1999.

5. Carvalho DMT. Financiamento da assistência médico-hospitalar no Brasil. Ciênc. Saúde Coletiva. 2007;12(4):879-92.

6. Medici AC. Financiamento e contenção de custos nas políticas de saúde: tendências atuais e perspectivas futuras. Rev Planej Políticas Públ. 1990;(4):83-93.

7. Medici AC. Economia e financiamento do setor de saúde no Brasil: balanços e perspectivas. São Paulo: Faculdade de Saúde Pública, Universidade de São Paulo; 1994.

8. Medici AC, Marques RM. Sistema de custos como instrumento de eficiência e qualidade dos serviços de saúde. CAD. Fundap 1996;16(19):47-59.

9. Falk JA. Gestão de custos para hospitais: conceitos, metodologias e aplicações. São Paulo: Atlas; 2001.

10. Horngren, CT; Foster, G. Dattar, SM. Contabilidade de custos. Rio de Janeiro: LTC-Livros Técnicos e Científicos; 2000.

11. Martins E. Contabilidade de custos. São Paulo: Atlas; 2003.

12. Francisco IMF, Castilho V. A enfermagem e o gerenciamento de custos. Rev Esc Enferm USP. 2002;36(3):240-4.

13. Matos AJ de. Gestão de custos hospitalares. São Paulo: Editora STS; 2002.

14. Zunta RSB. O faturamento gerado pelos procedimentos de enfermagem em uma unidade de terapia intensiva [dissertação]. São Paulo: Escola de Enfermagem, Universidade de São Paulo; 2006. 
15. Munhoz S, Barros SMO. O conhecimento dos gestores dos serviços de enfermagem sobre conceitos de custos hospitalares. Rev Paulista Enferm, UNIFESP. 2002;21(1):30-9.

16. Beulk R, Berto DJ. Gestão dos custos e resultados na saúde: hospitais, clínicas, laboratórios e congêneres. São Paulo: Saraiva; 2000.

17. Almeida $\mathrm{MH}$ de. Custos hospitalares em enfermagem. Rio de Janeiro: Cultura Médica; 1984.

18. Takes KL. Cost-effective practice: do or nurses care? Nurs Manage. 1992;23(4):96Q-96X.

19. Aburdene P, Naisbitt J. Megatendências para as mulheres. Rio de Janeiro: Rosa dos Tempos, 1993.

20. Bittar E, Castilho V. O custo médio direto do material utilizado em cirurgias de revascularização do miocárdio. Revista Assoc Med Bras [on line]. 2003; 49(3):225-60. [periódico na internet]. Disponível em http://www.scielo.br/pdf/ramb/v49n3/a27v49n3.pdf. Acesso em 17 out. 2009.

21. Sá CA. Contabilidade para não-contadores: princípios básicos para profissionais em mercados competitivos. Rio de Janeiro: SENAC-Rio; 2005.

22. Marion JC. Contabilidade Básica. São Paulo: Atlas; 2004. p.26.

23. Leite HP. Contabilidade para administradores. São Paulo: Atlas; 1997.

24. Martins D. Gestão financeira de hospitais. São Paulo: Atlas; 2001.

25. Horngren CT, Sunden GL, Stratton WO. Contabilidade gerencial. São Paulo: Pearson Frentice Hall; 2004.

26. Perez Junior JH, Oliveira LM, Costa RG. Gestão estratégica de custos. São Paulo: Atlas; 2005.

27. Castilho V. Gerenciamento de custos: análises de pesquisas produzidas por enfermeiras [livre-docência]. São Paulo: Escola de Enfermagem, Universidade de São Paulo; 2008.

28. Martins E. Contabilidade de custos. São Paulo: Atlas; 2006.

29. Megliorini E. Custos: análise de gestão. São Paulo: Pearson Frentice Hall; 2007. 
30. Pereira JCR. Análises de dados qualitativos: estratégias metodológicas para ciências da saúde, humanas e sociais. São Paulo: Editora Universidade de São Paulo; 2001.

31. Fernandes LO. Custo hospitalar: técnicas, problemas, soluções. São Paulo: LN; 1999.

32. Vilar Esteves MJ. A utilização dos custos hospitalares em hospitais paulistas: um estudo preliminar [dissertação] São Paulo: Faculdade de Saúde Pública, Universidade de São Paulo; 1992.

33. Leone GSG. Custos: planejamento, implantação e controle. São Paulo: Atlas; 2000.

34. Eldenburg LG, Wolcott SK. Gestão de custos: como medir, monitorar e motivar o desempenho. Rio de Janeiro: LTC; 2007.

35. Martins D. Custos e orçamentos hospitalares. São Paulo: Atlas; 2000.

36. Relvas TRS. Desenvolvimento de um modelo lógico para fundamentar a prática da mensuração inerente ao custeio e gerenciamento baseado em atividades: em estudo de caso no Banco Bradesco S.A. [tese]. São Paulo: Faculdade de Economia, Administração e Contabilidade e Atuária, Universidade de São Paulo; 2003.

37. Dallora MEL do V. Gerenciamento de custos de material de consumo em um hospital de ensino [dissertação]. Ribeirão Preto: Faculdade de Medicina, Universidade de São Paulo; 2007.

38. Oliveira JC. Estudo bibliométrico das publicações de custos em enfermagem no período de 1996 a 2000 [dissertação]. São Paulo: Escola de Enfermagem, Universidade de São Paulo; 2001.

39. Pimentel ER. Metodologia de custeio baseado em atividades: uma aplicação dos custos indiretos no centro cardiológico de um hospital [dissertação]. São Paulo: Pontifícia Universidade Católica de São Paulo; 2004.

40. Baumgartner RR, Matos AJ. Gestão financeira: a UTI como centro de custo hospitalar. In: Orlando JMC, Miquelin L. UTIs contemporâneas. São Paulo: Atheneu; 2008. p.177-86

41. Oliveira MTN, Giusti ACC. Sistema de programação financeira de curto e médio prazos: programação de caixa (cash flow). In: Gonçalves EL, organizador. Gestão hospitalar: administrando o hospital moderno. São Paulo: Saraiva; 2006. p. 255-320. 
42. Klein $C$. A utilização do método de custeio baseado em atividades ABC (Activity Based Costing) como ferramenta de auxílio na tomada de decisão na área hospitalar [dissertação]. Rio de Janeiro: Universidade Federal Rural do Rio de Janeiro; 2003.

43. Ching HY. Manual de custos de instituições de saúde: sistemas tradicionais de custos e sistema de custeio baseado em atividades (ABC). São Paulo: Atlas; 2001.

44. Nakagawa M. ABC: custeio baseado em atividades. São Paulo: Atlas; 2001.

45. Shank JK, Govindarajan V. A revolução dos custos: como reinventar a redefinir sua estratégia de custos para vencer em mercados crescentemente competitivos. Rio de Janeiro: Elsevier; 1997.

46. Cogan S. Custos e preços: formação e análise. São Paulo: Pioneira Thomson Learning; 2002.

47. Lo-Biondo Wood G, Haber J. Pesquisa em enfermagem. Rio de Janeiro: Guanabara-Koogan; 2001.

48. Brasil. Lei no. 9.637, de 15 de maio de 1998. Dispõe sobre a qualificação de entidades como organizações sociais, a criação do Programa Nacional de Publicização, a extinção dos órgãos e entidades que menciona e a absorção de suas atividades por organizações sociais, e dá outras providências. [legislação na internet]. Brasília; 1998. Disponível em:http://www.bresserpereira.org.br/Documents/MARE/OS/União-OSLei9.637-1998.pdf.

49. Lynn, MR. Determination and quantification of content validity. Nurs. Res. 1986;35(6):382-5.

50. Nicole AG. Construção e validação de indicadores de avaliação do acesso vascular de usuários em hemodiálise [dissertação]. São Paulo: Escola de Enfermagem, Universidade de São Paulo; 2009.

51. Silva CPR. Indicadores para avaliação de programas de controle de infecção hospitalar: construção e validação [dissertação]. São Paulo: Escola de Enfermagem, Universidade de São Paulo; 2005.

52. Fernandes MLV. Indicadores de avaliação de práticas de controle e de prevenção de infecção de trato urinário associada a cateter: construção e validação [dissertação]. São Paulo: Escola de Enfermagem, Universidade de São Paulo; 2005. 
53. Simon HA. Comportamento administrativo. Rio de Janeiro: Fundação Getúlio Vargas; 1971.

54. Melo MNB, Germano RM. No caminho das pedras: a supervisão de enfermagem nos hospitais públicos. Nursing (São Paulo). 2004;7(14):3944.

55. Castilho V, Gonçalves VLM. Gerenciamento de recursos materiais. In: Kurcgant P, coordenador. Gerenciamento em enfermagem. Rio de Janeiro: Guanabara Koogan; 2005. p.157-70.

56. Campos CV, Santos LGS. A percepção do enfermeira sobre o seu papel no gerenciamento de custos hospitalares. Rev.Min.Enferm. 2008;12(2): 


\section{APÊNDICES}




\section{APÊNDICE A \\ INSTRUMENTO DE COLETA DE DADOS A- CARACTERIZAÇÃO DA \\ INSTITUIÇÃO DE SAÚDE}

(somente para o cargo da enfermagem de maior nível hierárquico)

\section{Perfil Institucional}

Siglas da Instituição de Saúde:

Número de leitos:

Especialidades atendidas:

( ) Clínica Médica

( ) Ginecologia e Obstetrícia

( ) Pediatria

( ) Clínica Cirúrgica

( ) Unidade de Urgência e Emergência

( ) Terapia Intensiva

( ) Cardiologia

( ) Ortopedia

( ) Outros

Nível de referência: ( ) Primário （）Secundário （）Terciário

( ) Quartenário

Tipo de instituição:( )hospital público ( )hospital privado ( )organização de saúde

1) Qual método de custeio é utilizado na instituição com a finalidade gerencial de custos?

( ) absorção por centro de custo ( ) atividade $(A B C) \quad(\quad)$ custeio direto/variável

( ) custeio padrão ( ) outros

2) Há quanto tempo o sistema de custeio foi implantado? anos

3) Você conhece o orçamento do serviço de enfermagem?

( ) Sim ( ) Não

Por que?

4) Você participa da elaboração do orçamento do serviço de enfermagem?

( ) Sim ( ) Não

Por que?

5) As unidades/setores são organizadas como centros de custo?

( ) Sim ( ) Não

Por que?

6) Você conhece o orçamento do serviço de enfermagem?

( ) $\operatorname{Sim}$ ( ) Não

Por quê?

7) Você participa da elaboração do orçamento do serviço de enfermagem?

( ) $\operatorname{Sim}($ ) Não

Por quê? 
8) Quais são as suas atividades, como enfermeira chefe, relacionadas à gestão de custos?

9) Quais são as atividades das enfermeiras das Unidades relacionadas à gestão de custos?

10) Existem outras enfermeiras com atividades relacionadas à gestão de custos ligadas ou não ao Serviço de Enfermagem?

( ) Não ( ) Sim

Se Sim, onde estão lotadas e quais são suas atividades?

10) Você considera que gestão de custos é uma das atividades gerenciais das enfermeiras?

( ) Sim ( ) Não

Por quê?

11) As enfermeiras estão capacitadas para a gestão de custos no seu hospital?

( ) Sim ( ) Não

Por quê?

12) Você gostaria de comentar algo que não foi abordado sobre sua experiência relacionada à gestão de custos? 


\section{APÊNDICE B \\ INSTRUMENTO DE COLETA DE DADOS B - CONHECIMENTO DAS ENFERMEIRAS NO GERENCIAMENTO DE CUSTOS \\ (para enfermeiras)}

Parte I: Caracterização das enfermeiras

1) Sexo:

() Feminino ( ) Masculino

2) Idade: anos

3) Tempo de formação: anos

4) Tempo de atuação na instituição: anos

5) Cargo que ocupa:

6) Tempo de atuação no cargo: anos

7) Titulação:

( ) Especialização em

( ) Mestrado em

( ) Doutorado em

( ) Outros

\section{Parte II. Avaliação do conteúdo das práticas gerenciais em custos}

8) Você conhece os custos do seu setor?

( ) Sim ( ) Não Por que?

9) Você conhece o sistema de custeio utilizado no hospital em que atua para gerar os relatórios de custos dos serviços e procedimentos?

( ) $\operatorname{Sim}$ ( ) Não Por que?

10) Você recebe relatórios periodicamente sobre os custos da sua unidade?

( ) Sim ( ) Não Por que?

11) Você participa de reuniões periódicas para discussão da evolução dos custos do seu setor?

( ) Sim ( ) Não Por que?

12) Você conhece o orçamento do serviço de enfermagem?

( ) Sim ( ) Não Por que?

13) Você conhece o orçamento do setor que atua?

( ) Sim ( ) Não Por que?

14) Você participa da elaboração do orçamento do setor que atua?

( ) Sim ( ) Não Por que?

15) Você possui acesso às informações necessárias para a elaboração do orçamento do setor que atua?

( ) Sim ( ) Não Por que?

16) Você conhece o faturamento do seu setor?

( ) Sim ( ) Não Por que?

17) Você participa da elaboração de custos de procedimentos/ pacotes?

( ) Sim ( ) Não Por que?

18) Você realiza outras atividades relacionada a custos em seu setor?

( ) Sim ( ) Não Por que? 


\section{Parte III. Conhecimento das enfermeiras sobre principais conceitos de custos hospitalares}

19) A aquisição de materiais e medicamentos pelo hospital com a finalidade de gerar assistência hospitalar é?

( ) Custo ( ) Gasto ( ) Despesa ( ) Investimento ( ) desconheço 20) A mão de obra utilizada direta ou indiretamente na prestação da assistência de enfermagem é?

( ) Custo ( ) Gasto ( ) Despesa ( ) Investimento ( ) desconheço 21) Os valores referentes ao rateio de água, energia elétrica, depreciação de equipamentos são?

( ) Gastos ( ) Custos ( ) Despesas ( ) Perdas ( ) desconheço 22) Um sacrifício financeiro que a instituição tem para a obtenção de um produto ou serviço é?

( ) Gasto ( ) Custo ( ) Despesa ( ) Perda ( ) desconheço

23) O desenvolvimento de programas de treinamento e desenvolvimento para os funcionários do hospital, assim como a aquisição de um bisturi cirúrgico elétrico são?

( ) Custo ( ) Gasto ( ) Despesa ( ) Investimento ( ) desconheço

24) Gastos anormais, involuntários que ocorrem na instituição gerando ou não a assistência ao paciente é?

( ) Custo ( ) Gasto ( ) Despesa ( )Perda ( ) desconheço

25) Nas planilhas de custos dos setores, quando identificamos os custos referentes aos salários de funcionários, este custo é?

( ) Direto ( ) Indireto ( ) desconheço

26) Nas planilhas de custos dos setores, quando identificamos os custos que utilizam as bases de rateio, estes custos são?

( ) Diretos ( ) Indiretos ( ) desconheço

27) Os custos inerentes à produção dos serviços hospitalares que variam de acordo com a produção são custos?

( ) Fixos ( ) Variáveis ( ) desconheço

28) Os custos operacionais relacionados por exemplo à infra-estrutura, e que permanecem constantes independente da demanda são custos?

( ) Fixos ( ) Variáveis ( ) desconheço

29) Para realizar o cálculo estimado dos custos indiretos relacionados à assistência prestada ao paciente utilizamos qual critério?

( ) gastos ( ) despesas ( ) bases de rateio ( ) não há critério, utilizam-se os próprios custos indiretos ( ) desconheço

30) A unidade mínima onde se dá a acumulação de custos, é denominada:

( ) centro de custo ( ) unidade de produção ( ) centro de negócio

( ) centro de custo improdutivo ( ) desconheço

31) O setor hospitalar que atua diretamente na prestação da assistência ao paciente é um:

( ) centro de custo ( ) unidade de produção ( ) centro de custo produtivo

( ) centro de custo auxiliar ( ) desconheço

32) O setor hospitalar que atua indiretamente na prestação da assistência ao paciente é um:

( ) centro de custo ( ) unidade de produção ( ) centro de custo produtivo

( ) centro de custo auxiliar

( ) desconheço 
33) O que é um método de custeio?

( ) método de apropriação de custos

( ) método de cálculo dos custos diretos

( ) método de cálculo indireto dos custos

( ) desconheço

Parte IV. Condições institucionais para a realização do gerenciamento de custos

34) Você se sente preparado (a) para gerenciar custos hospitalares?

( ) Sim ( ) Não Por que?

35) Você encontra dificuldades no gerenciamento de custos?

( ) Sim ( ) Não

Quais?

36) De acordo com sua experiência profissional, você identifica vantagens no gerenciamento de custos? Quais?

37) Você acredita que o gerenciamento de custos é uma atribuição do enfermeira? Por que? 


\section{APÊNDICE C}

\section{INSTRUMENTO PARA VALIDAÇÃO OPINATIVA DO CONTEÚDO PARA MENSURAR O CONHECIMENTO DAS ENFERMEIRAS NO GERENCIAMENTO DE CUSTOS}

\section{Parte I: Caracterização das enfermeiras gestores hospitalares}

1)Sexo:

( ) Feminino ( ) Masculino

2) Idade: anos

3) Tempo de formação: anos

4) Instituição de trabalho: ( ) Pública ( ) Privada

5) Cargo/função exercida:

6) Graduação em:

7) Titulação:

( ) Especialização em

( ) Mestrado em

( ) Doutorado em

( ) Outros

Prezado avaliador, recomenda-se que o senhor (a) tenha em mãos o instrumento de coleta de dados $B$, proceda sua leitura e acompanhamento para preencher o questionário com o conteúdo abaixo, que será utilizado para a avaliação de cada uma das questões. Por gentileza, preencha na íntegra o instrumento. Muito Obrigada!

Parte II. Avaliação do conteúdo das práticas gerenciais em custos: as questões abaixo prevêem a avaliação do conteúdo sobre as práticas gerenciais relacionadas a gerenciamento de custos desenvolvidas pelas enfermeiras. Por favor, considere as proposições, assinale a alternativa pertinente e, utilize o espaço para comentários e sugestões, caso seja necessário aperfeiçoamento.

Questão 8) ( ) Manter （） Excluir Alterar:

Questão 9) ( ) Manter （） Excluir

Alterar:

Questão 10) ( ) Manter （） Excluir

Alterar: 
Questão 11) ( ) Manter

Alterar:

( ) Excluir

Questão 12)（）Manter （）Excluir

Alterar:

Questão 13) ( ) Manter ( ) Excluir

Alterar:

Questão 14) ( ) Manter （ ) Excluir

Alterar:

Questão 15)( ) Manter ( ) Excluir

Alterar:

Questão 16)( ) Manter ( ) Excluir

Alterar:

Questão 17) ( ) Manter （ ） Excluir

Alterar:

Questão 18)( ) Manter （）Excluir

Alterar:

Parte III. Conhecimento dos gestores sobre principais conceitos de custos hospitalares: as questões abaixo prevêem a avaliação do conhecimento dos gestores sobre os principais conceitos de custos. Por favor, considere as proposições, assinale a alternativa pertinente e, utilize o espaço para comentários e sugestões, caso seja necessário aperfeiçoamento.

Questão 19) ( ) Manter （ ) Excluir

Alterar:

Questão 20) ( ) Manter （） Excluir

Alterar: 
Questão 21) ( ) Manter

Alterar:

( ) Excluir

Questão 22) ( ) Manter （）Excluir

Alterar:

Questão 23) ( ) Manter （ ） Excluir

Alterar:

Questão 24) ( ) Manter （ ） Excluir

Alterar:

Questão 25)（）Manter （）Excluir

Alterar:

Questão 26) ( ) Manter （）Excluir

Alterar:

Questão 27) ( ) Manter （） Excluir

Alterar:

Questão 28) ( ) Manter （）Excluir

Alterar:

Questão 29) ( ) Manter （ ） Excluir

Alterar:

Questão 30) ( ) Manter （） Excluir

Alterar:

Questão 31) ( ) Manter （ ） Excluir

Alterar:

Questão 32) ( ) Manter （ ） Excluir

Alterar: 
Questão 33) ( ) Manter

Alterar:

( ) Excluir

Parte IV. Condições institucionais para a realização do gerenciamento de custos: as questões abaixo prevêem a avaliação do conteúdo sobre as condições institucionais para a realização do gerenciamento de custos. Por favor, considere as proposições, assinale a alternativa pertinente e, utilize o espaço para comentários e sugestões, caso seja necessário aperfeiçoamento.

Questão 34) ( ) Manter （）Excluir

Alterar:

Questão 35) ( ) Manter （）Excluir

Alterar:

Questão 36) ( ) Manter ( ) Excluir

Alterar:

Questão 37) ( ) Manter （）Excluir

Alterar:

Conclusão

O conjunto de questões é representativo frente ao universo teórico do processo de gerenciamento de custos realizados por enfermeiras em unidades hospitalares? ( ) sim ( ) não

Comentários e sugestões:

Há necessidade de incluir algum outro elemento? ( ) sim （） não Quais? 


\section{APÊNDICE D}

\section{Termo de Consentimento Livre e Esclarecido}

O senhor(a) está convidado(a) a participar voluntariamente de um estudo com título "A participação das enfermeiras na gestão de custos em organizações hospitalares", conduzido por mim, Karina Gomes Lourenço Mendes, aluna regularmente matriculada no Programa de Pós Graduação, doutorado em Administração em Serviços de Enfermagem na Escola de Enfermagem da Universidade de São Paulo, sob orientação da Profa Dra. Valéria Castilho.

Este projeto será realizado com as enfermeiras que atuam nas instituições hospitalares com o objetivo de avaliar o conhecimento e suas atividades relacionadas ao gerenciamento de custos, desenvolvidas pelos(as) enfermeiras(as), no município de São Paulo.

Seu nome não será utilizado em qualquer fase da pesquisa o que garante seu anonimato e a divulgação dos resultados será feita de forma a não identificar os voluntários.

Para participar deste estudo o(a) Senhor(a) será responderá os questionários a fim de fornecer informações sobre a sua prática gerencial com relação aos custos hospitalares.

Gostaríamos de deixar claro que sua participação é voluntária e que poderá recusar-se a participar ou retirar o seu consentimento, ou ainda descontinuar sua participação se assim o preferir, sem penalização/punição trabalhista na recusa de sua participação tanto institucional como profissional.

Se você concordar em participar desta pesquisa, deverá rubricar todas as páginas deste TCLE e apor a sua assinatura na última página. $\mathrm{O}$ pesquisador responsável também rubricará todas as páginas do TCLE e assinará na última página. Você ficará com uma cópia rubricada e assinada deste Termo e em caso de dúvida(s) e outros esclarecimentos sobre esta pesquisa você poderá entrar em contato com o pesquisador responsável, assim como você terá acesso aos dados da pesquisa sempre que desejar e 
a equipe se compromete a informá-lo quando estiver de posse dos resultados finais.

Agradecemos sua colaboração e colocamo-nos à disposição para esclarecimentos.

\section{Eu}

RG confirmo que Karina Gomes Lourenço

Mendes explicou-me os objetivos desta pesquisa, bem como, a forma de participação. As alternativas para minha participação também foram discutidas. Eu li e compreendi este Termo de Consentimento, portanto, eu concordo em dar meu consentimento para participar como voluntário desta pesquisa.

São Paulo, de de 2011.

(Assinatura do sujeito da pesquisa)

Eu Karina Gomes Lourenço Mendes obtive de forma apropriada e voluntária - Consentimento Livre e Esclarecido do sujeito da pesquisa ou representante legal para a participação na pesquisa.

Enfa. Ms.Karina Gomes Lourenço Mendes Tel: (11) 3347-1074 karinal@usp.br

Caso haja alguma dúvida, o sujeito da pesquisa poderá entrar em contato com o CEP da instituição de saúde no telefone (11) 2151-3739 ou por email: CEP@einstein.br. Email Comitê de Ética da EEUSP: edipesq@usp.br. 
ANEXOS 
